\title{
Editor:
}

Dr. Adi Wijayanto, S.Or., S.Kom., M.Pd., AIFO.

Rora Rizky Wandini, M.Pd.I

Rifqi Festiawan, S.Pd, M.Pd., AIFO.

Narulita Evia Riskhayanti, S.Kom.

Kata Pengantar:

Prof. Dr. H. Akhyak, M.Ag.

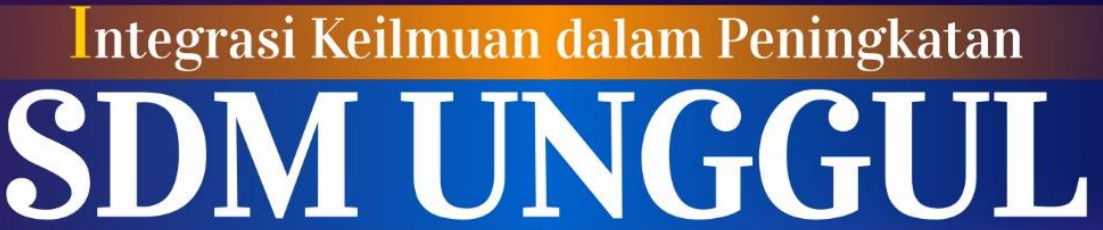

Berkompetensi
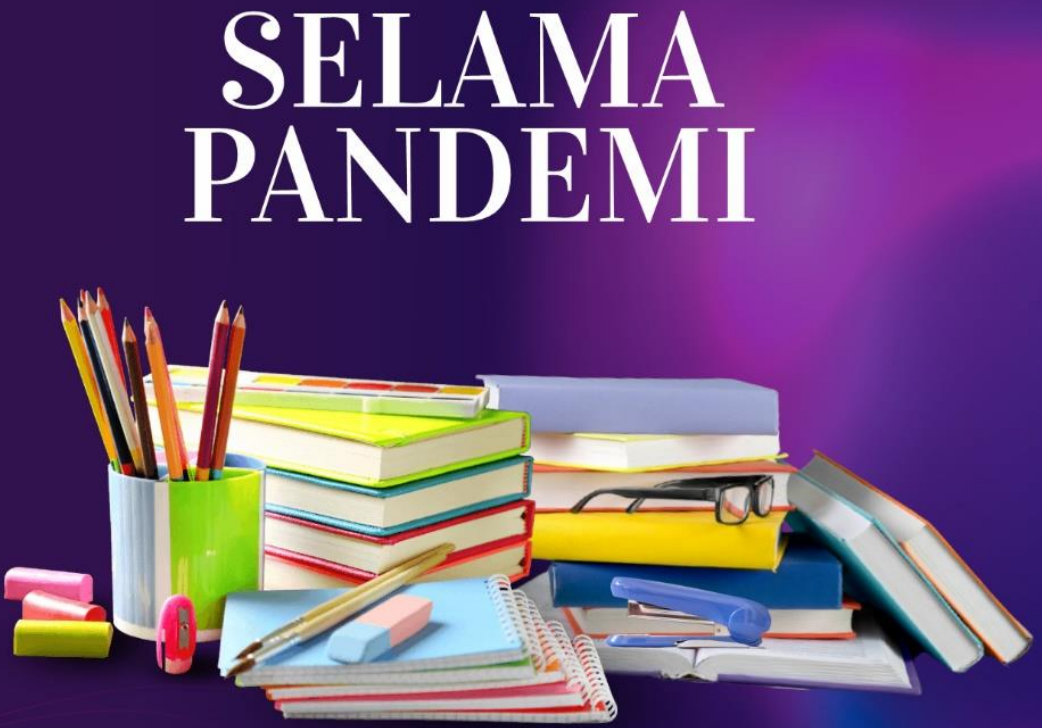

Bea Hana Siswati - Abdul Gafur Marzuki - Adhitya Rol Asmi

Irawati - Khairuddin Hasan - Tuti Nuriyati - Husni Awali - Iim Ibrohim

Mawardi - Widiastuti - Siti Marlida - Supriadi - Fikfik Taufik - Irma Fauziah

Jonas Klemens G.D. Gobang - Molly Mustikasari - Sufian Suri

Cintami Farmawati - Cecep Taufikurrohman - Takdir Alisyahbana

Rahmat Alamsyah - Sholihatul Hamidah Daulay - Yeheskial Nggandung

Moch. Fadlani Salam - Abdul Khamid - Fitri Anjani - Mukhlishah

Teddy Dyatmika - Yudi Haryadi - Heri Budianto 
Prof. Dr. H. Akhyak, M.Ag.

\section{INTEGRASI KEILMUAN DALAM PENINGKATAN SDM UNGGUL BERKOMPETENSI SELAMA PANDEMI}

Bea Hana Siswati - Abdul Gafur Marzuki - Adhitya Rol Asmi - Irawati Khairuddin Hasan - Tuti Nuriyati - Husni Awali - Iim Ibrohim - Mawardi Widiastuti - Siti Marlida - Supriadi - Fikfik Taufik - Irma Fauziah Jonas Klemens G.D. Gobang - Molly Mustikasari - Sufian Suri Cintami Farmawati - Cecep Taufikurrohman - Takdir Alisyahbana Rahmat Alamsyah - Sholihatul Hamidah Daulay - Yeheskial Nggandung Moch. Fadlani Salam - Abdul Khamid - Fitri Anjani - Mukhlishah Teddy Dyatmika - Yudi Haryadi - Heri Budianto

\section{Editor:}

Dr. Adi Wijayanto, S.Or., S.Kom., M.Pd., AIFO.

Rora Rizky Wandini, M.Pd.I Rifqi Festiawan, S.Pd, M.Pd., AIFO. Narulita Evia Riskhayanti, S.Kom. 


\section{INTEGRASI KEILMUAN DALAM PENINGKATAN SDM UNGGUL BERKOMPETENSI SELAMA PANDEMI}

Copyright (C) Bea Hana Siswati, dkk., 2021

Hak cipta dilindungi undang-undang

All right reserved

Layouter: Muhamad Safi'i

Desain cover: Dicky M. Fauzi

Editor: Adi Wijayanto, dkk.

viii +225 hlm: 14 × $21 \mathrm{~cm}$

Cetakan: Pertama, September 2021

ISBN: 978-623-6364-28-4

\section{Anggota IKAPI}

Hak cipta dilindungi undang-undang.

Dilarang memplagiasi atau memperbanyak seluruh isi buku ini tanpa izin tertulis dari penerbit.

Diterbitkan oleh:

\section{Akademia Pustaka}

Perum. BMW Madani Kavling 16, Tulungagung

Telp: 081216178398

Email: redaksi.akademia.pustaka@gmail.com

Website: www.akademiapustaka.com 


\section{Kata Pengantar}

\section{Ahamdulillahi Rabbilalamin kehadirat Allah SWT yang $A_{\text {maha kuasa atas perkenan-Nya buku bunga rampai edisi }}$}

September tahun 2021 yang berjudul "Integrasi Keilmuan dalam Peningkatan SDM Unggul Berkompetensi selama Pandemi" dapat diselesaikan dengan sebaik-baiknya atas sumbangsih ide/gagasan dan pemikiran dari para pakar pendidikan dan stake holder.

Kehadiran buku bunga rampai di masa Pandemi Covid-19 dapat memberi makna strategis oleh karena dalam pembahasannya banyak ditorehkan para pakar pendidikan berbagai pemikiran dengan narasi yang ringan dan mudah dipahami terkait dengan eksistensi penyelenggaraan berbagai bidang keilmuan. Bagaimana eksistensinya sangat perlu dibahas dari berbagai sudut pandang para pakar pendidikan ditengah pemikiran antara pesimis dan optimis bahwa belajar daring di tengah kondisi pandemi covid-19 akan menurunkan hasil belajar oleh karena sulitnya melakukan pengawasan sejauh mana siswa di rumah serius belajar secara daring tanpa pengawasan langsung dari guru dan orangtua.

Fakta dilapangan memang tidak dapat dipungkiri sejauhmana siswa ada dalam pengawasan para guru dan orangtua selama proses belajar daring. Kondisi pandemi Covid-19 ini memunculkan banyak estimasi baik yang bersifat positif maupun negatif akan keberhasilan dari penyelenggaraan pendidikan secara daring di rumah siswa. Fenomena seperti ini menjadi kegusaran dalam pikiran para guru dan siswa dan kegusaran ini tidak luput dari pemikiran para penulis buku bunga rampai ini. 
Kehadiran buku bunga rampai ini sangatlah tepat di tengah kondisi pandemi Covid-19 varian baru. Semoga tulisan ringan dengan berbagai topik yang menarik disampaikan para penulis, memberi manfaat bagi para pembaca, guru, siswa, orangtua. Upaya menghilangkan virus Covid-19 terus dilakukan Pemerintah RI tetapi penyiapan SDM unggul tidak boleh terhenti olehkarena ganasnya penyebaran Virus corona yang berimbas membuat banyak pihak berpikir pesimis dan optimis yang bercampur aduk dalam pikirannya termasuk para guru dan siswa.

Tulungagung, 11 September 2021

Prof. Dr. H. Akhyak, M.Ag.

Direktur Pascasarjana UIN SATU 


\section{Daftar Isi}

KATA PENGANTAR .......................................................................... ii

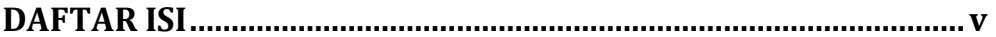

\section{BAB I}

TANTANGAN DAN SOLUSI DUNIA PENDIDIKAN

TANTANGAN DAN SOLUSI PEMBELAJARAN BIOLOGI PADA MASA PANDEMI COVID-19 ...................................................... 3

Dr. Bea Hana Siswati, S.Pd., M.Pd. (Universitas Jember)

OPTIMALISASI PEMBELAJARAN DARING DI PERGURUAN TINGGI PADA MASA PANDEMI

Dr. Abdul Gafur Marzuki, S.Pd. M.Pd. (UIN Datokarama Palu)

TANTANGAN GENERASI EMAS INDONESIA 2045

DITENGAH NEW NORMAL COVID-19 DALAM PERSPEKTIF PENDIDIKAN TINGGI

Adhitya Rol Asmi, M.Pd. (Universitas Sriwijaya)

PEMASARAN DIGITAL SEBAGAI TANTANGAN, PELUANG DAN SOLUSI BISNIS PERTUMBUHAN EKONOMI UMKM DI MASA PANDEMI COVID-19

Irawati, S.E.,M.E.Sy. (Universitas Muhammadiyah Bandung)

PENDIDIKAN BERBASIS KELUARGA (TANTANGAN DI ERA COVID-19)

Khairuddin Hasan, M.Pd. (STAIN Teungku Dirundeng Meulaboh)

OPTIMALISASI ETOS KERJA SEORANG PENDIDIK DALAM MENINGKATKAN EFEKTIVITAS BELAJAR MENGAJAR DI MASA PANDEMI.

Tuti Nuriyati, M.Pd. (STAIN Bengkalis, Riau)

MEMBANGUN KOMPETENSI SUMBER DAYA MANUSIA SEBAGAI UPAYA MENINGKATKAN PENDAPATAN EKONOMI PASCA PANDEMI COVID-19.

Husni Awali, M.M. (Institut Agama Islam Negeri Pekalongan) 
TETAP BERPRESTASI WALAU PANDEMI TINGGI

Dr. Iim Ibrohim, M.Ag. (FAI UM Bandung, dan Yayasan Mutiara Embun Pagi)

PANDEMI (BUKAN) SOLUSI PENDIDIKAN ERA REVOLUSI INDUSTRI 4.0.

Mawardi, M.Pd. (Dayah Terpadu Almuslimun Aceh Utara)

PEMANFAATAN WAKTU LUANG MAHASISWA DALAM

PENINGKATAN DIRI DI TENGAH PANDEMI COVID-19..... 58

Dra. Widiastuti, MM. (Universitas Darma Persada)

\section{BAB II}

\section{KEGIATAN SPIRITUAL SAAT PANDEMI}

OPTIMALISASI KOMPETENSI DA'IYYAH DI MASA PANDEMI COVID-19

Siti Marlida,M.Ag. (Universitas Muhammadiyah Bandung)

PANDEMI, QOLBU, 'BEDUK' \& KETAATAN MAHLUK 75

Supriadi, MM. (STAI Bumi Silampari)

TAHAMMUL ILMI DI MASA PANDEMI. 80

Dr. Fikfik Taufik, S.S, M.Sy. (Universitas Muhammadiyah Bandung)

PEMBIASAAN KARAKTER CINTA AL-QUR'AN BAGI ANAK DI MASA PANDEMI COVID-19

Irma Fauziah, M.Pd. (UIN SATU Tulungagung)

THE POWER OF “GRACIA" REFLEKSI ATAS PENGALAMAN

SEBAGAI PENYINTAS COVID-19

Dr. Jonas Klemens G.D.Gobang, S.Fil.,M.A. (Universitas Nusa Nipa Indonesia - Maumere, Flores, NTT)

BERINVESTASI SYARIAH DI ERA PANDEMI, MUNGKINKAH?103 Molly Mustikasari, ME. (Universitas Muhammadiyah Bandung) 
PENGAJIAN AL QUR'AN DI DAERAH PEDALAMAN ACEH SELAMA PANDEMI

Sufian Suri, Lc., MA. (IAIN Lhokseumawe)

QONA'AH SEBAGAI KUNCI KEBAHAGIAAN HIDUP SELAMA

PANDEMI COVID-19.

Cintami Farmawati (IAIN Pekalongan)

PANDEMI DALAM PERSPEKTIF TEOLOGI SUNNI

Cecep Taufikurrohman, MA., Ph.D. (Universitas

Muhammadiyah Bandung)

OPTIMALISASI FUNGSI MASJID DI MASA PANDEMI COVID-

19

Takdir Alisyahbana, M.Pd.I. (STAI Bumi Silampari)

MENINGKATKAN KWALITAS SUMBER DAYA MANUSIA GURU NGAJI PADA MASA PANDEMI COVID-19

Rahmat Alamsyah, S.Ag., M.Ag. (Universitas Muhammadiiyah Bandung)

\section{BAB III}

PERANAN PENDIDIK DAN ORANG TUA SAAT PANDEMI

MENJADI PENGAJAR HEBAT DI TENGAH COVID-19 144

Dr. Sholihatul Hamidah Daulay, S.Ag., M.Hum. (Universitas Islam Negeri Sumatera Utara)

PROFESI GURU DALAM MENGHADAPI PANDEMI COVID-19151

Drs. Yeheskial Nggandung, M.Si. (Program Studi Pendidikan Ekonomi FKIP Universitas Nusa Cendana Kupang)

PENGEMBANGAN SUMBER DAYA INSANI DI LEMBAGA PENDIDIKAN ISLAM

Mochamad Fadlani Salam, S.Pd.I, M.Pd. (Universitas Muhammadiyah Bandung)

OPTIMALISASI PERAN PENGAWASAN ORANGTUA DALAM MENINGKATKAN PELAKSANAAN PEMBELAJARAN ONLINE DI ERA PANDEMI COVID-19 166 Abdul Khamid, M.Pd. (Institut Agama Islam Negeri Salatiga)

PENINGKATAN KUALITAS PENDIDIK MENUJU SUMBER DAYA MANUSIA YANG UNGGUL DAN BERMARTABAT 
DALAM BIDANG PENDIDIKAN DI MASA PANDEMIK COVID19

Fitri Anjani,S.Pd. (SDN Wonokusumo Mojosari Mojokerto)

PENDIDIKAN KEMANDIRIAN ANAK DI MASA PANDEMI COVID-19.

Hj. Mukhlishah. Dra. M.Ag. (Universitas Muhammadiyah Bandung)

KOMUNIKASI ORANG TUA DAN ANAK SELAMA

PEMBELAJARAN ONLINE.

Teddy Dyatmika, M.I.Kom. (IAIN Pekalongan)

KORELASI PROCESS ORIENTED MANAGEMENT DENGAN SDM UNGGUL

Yudi Haryadi S.E.,M.M. (Universitas Muhammadiyah Bandung)

PERSPEKTIF PENDIDIK DALAM MENANAMKAN PENDIDIKAN KARAKTER DAN MENGATASI PROBLEMATIKA PEMUDA

Heri Budianto, M.A.P. (MAN Sumenep) 


\section{BAB I \\ TANTANGAN DAN SOLUSI DUNIA PENDIDIKAN}

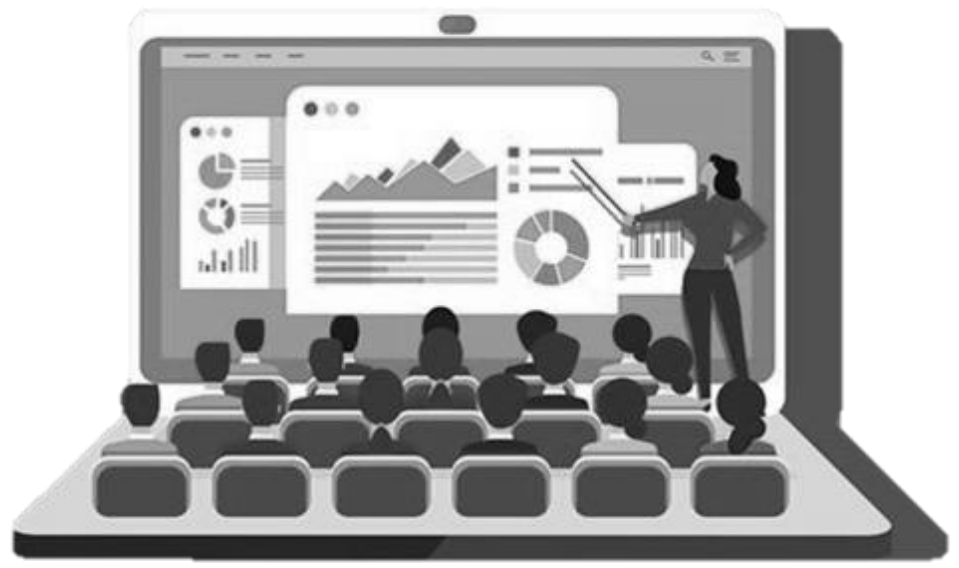




\title{
TANTANGAN DAN SOLUSI PEMBELAJARAN BIOLOGI PADA MASA PANDEMI COVID-19
}

\author{
Dr. Bea Hana Siswati, S.Pd., M.Pd ${ }^{1}$ \\ (Universitas Jember)
}

\begin{abstract}
"Sebagai pendidik Biologi dari mulai Sekolah Dasar sampai Perguruan Tinggi baiknya mulai berpikir bagaimana memanfaatkan musim pandemic ini secara positif"
\end{abstract}

Pandemic Covid-19 ini memaksa pendidik di Indonesia Puntuk melakukan perubahan terutama yang terkait dengan cara mengajar. Sekarang saatnya bagi para pendidik untuk memikirkan kembali apa dan bagaimana cara mengajar siswa dengan pembelajaran jarak jauh. Bagaimana seorang pendidik mampu menciptakan peluang dari krisis yang terjadi adalah PR yang sangat besar bagi pendidik. Jadi sebagai pendidik Biologi dari mulai Sekolah Dasar sampai Perguruan Tinggi baiknya mulai berpikir bagaimana memanfaatkan musim pandemic ini secara positif. Pembelajaran biologi merupakan pembelajaran yang di dalamnya membutuhkan banyak praktikum. Kondisi pandemi seperti ini membuat pembelajaran biologi dilakukan menjadi kurang maksimal. Berikut dipaparkan beberapa permasalahan dalam pembelajaran selama pandemic Covid-19 yang didasarkan dari hasil penelitian selama 2 tahun terakhir ini.

1 Penulis lahir di Mojokerto, 01 April 1990, penulis merupakan Dosen Universitas Jember dalam bidang Pendidikan Biologi, penulis menyelesaikan gelar Sarjana hingga Doktor Pendidikan Biologi di Universitas Negeri Malang (2012, 2014, dan 2017). 


\section{Permasalahan Pembelajaran Online Selama Pandemic Covid-19 Berlangsung}

Gikas \& Grant (2013) menjelaskan bahwa pelaksanaan pembelajaran yang dilakukan secara online membutuhkan sebuah perangkat mobile seperti smartphone, tablet, \& laptop untuk dapat digunakan mengakses informasi dimana saja dan kapan saja. Abidah dkk. (2020) juga membahas berbagai media yang bisa digunakan untuk mendukung pembelajaran online secara gratis, sederhana, dan dapat diakses dengan mudah menggunakan smartphone. Dengan tersedianya akses belajar yang banyak macamnya, bukan berarti pembelajaran daring tidak memiliki kendala dalam pelaksanaannya. Beberapa kendala tersebut diantaranya:

1. Kesiapan Guru Mengajar Online: Penelitian yang dilakukan oleh Putri, dkk. (2020) pada 109 guru mengungkap kesiapan guru dalam melakukan pembelajaran online masih kurang karena $42 \%$ guru yang diteliti belum pernah melakukan pembelajaran online sebelumnya. Tetapi itu bukan merupakan suatu hambatan, hal ini terjawab dari hampir 95\% guru pada akhirnya melakukan pembelajaran online selama pandemic Covid-19 melanda negeri ini.

2. Dilema Pelaksanaan Praktikum Online: Alternatif untuk menjalankan praktikum online telah di sampaikan oleh Putri, dkk (2020) yang mengungkap bahwa kegiatan praktikum selama musim pandemic dapat dilaksanakan dengan cara menggunakan virtual laboratorium atau juga melakukan bimbingan praktikum sederhana untuk dilakukan di rumah masing-masing peserta didik. Masiah \& Primawati (2021) juga mengungkap bahwa ada beberapa kegiatan praktikum yang dilakukan di rumah membuat mahasiswa kesulitan dalam pelaksanaannya.

3. Kesulitan dan Kebosanan Pembelajaran Online: Komisi Perlindungan Anak Indonesia (KPAI) pada tahun 2020 telah menerima 246 pengaduan terkait permasalahan- 
permasalahan pembelajaran online pada April 2020 dan hasil penelitian yaitu $77,8 \%$ siswa menyatakan kesulitan menjalani belajar online. Penelitian yang dilakukan oleh Masiah \& Primawati (2021) mengungkap 91\% siswa tidak suka dengan pembelajaran online, kebosanan siswa terjadi karena mereka terus menerus belajar di depan laptop atau di depan layar ponselnya. Dalam lingkup mahasiswa Khasanah dkk. (2020) mengungkap sekitar $80 \%$ mahasiswa mengalami kebosanan saat melaksanakan pembelajaran daring. Kebosanan dipicu oleh kurangnya interaksi antar individu, tidak bisa mengatur waktu, kurang fokus (konsentrasi). Hal ini juga didukung oleh penelitian yang dilakukan Wisacita (2020) yang menjelaskan bahwa dalam pembelajaran jarak jauh hendaknya diimbangi dengan kreativitas, inovasi serta kerja sama yang baik \& selaras antara pendidik dan peserta didik dengan tujuan untuk meminimalisir kebosanan yang mungkin terjadi.

4. Koneksi Internet: Masalah yang umum terjadi adalah terkait jaringan. Memiliki smartphone serta kuota internet yang mencukupi tidak sertamerta membuat siswa lancar dalam menjalani pembelajaran online. Penelitian yang dilakukan oleh Masiah \& Primawati (2021) mengungkap terdapat 55\% siswa yang berada dalam wilayah yang memiliki koneksi internet kurang stabil. Khasanah, dkk. (2020) juga menjelaskan bahwa sekitar 61\% mahasiswa mengalami kendala jaringan internet saat melakukan pembelajaran daring. Faktor penyebabnya pun bermacam-macam mulai dari tiba-tiba pemadaman, cuaca yang tidak mendukung atau memang berada pada lingkungan yang masih sulit untuk mendapat akses internet.

5. Sulitnya Memahami Pelajaran dan dalam Mengerjakan tugas: Tidak semua orang mampu beradaptasi dengan cepat terhadap suatu perubahan, termasuk juga perubahan dalam hal proses pembelajaran. 
Pembelajaran yang biasanya didapatkan secara tatap muka kemudian diganti secara online menimbulkan ketidaksiapan pada diri seseorang. Kesulitan pemahaman terhadap materi, menurut Khasanah, dkk. (2020) diantaranya media pembelajaran yang disediakan pendidik kurang menarik minat belajar peserta didik, pendidik minim memberikan penguatan materi selama proses pembelajaran, sumber belajar yang kurang memadai untuk mendukung proses belajar. Selain itu, sebagai tambahan peserta didik juga mengalami kendala dalam menyampaikan pendapat, bertanya atau bahkan menyangga selama proses pembelajaran berlangsung. Tugas yang diberikan oleh pendidik pun tidak bisa dikerjakan dengan optimal, alasannya adalah kurang memahami materi, terlalu overload tugas, ditambah lagi adanya tugas kelompok dan kelompok yang sudah terbentuk anggotanya susah untuk diajak bekerja sama. Akhirnya pemahaman materi yang seharusnya diperoleh penuh oleh peserta didik menjadi tidak maksimal.

Beberapa Peluang dan Solusi yang dapat dijadikan pertimbangan untuk Pembelajaran Online baik untuk Pembelajaran Biologi maupun Pembelajaran yang lainnya, diantaranya:

1. Memanfaatkan teknologi secara maksimal: Wisacita (2020) menjelaskan bahwa kemampuan memanfaatkan teknologi harus dimiliki oleh semua pendidik maupun tenaga pendidik. Untuk memaksimalkan proses belajar maka manajemen yang bergerak dalam bidang Pendidikan, misalnya tenaga administrasi, kurikulum, presensi serta pengembangan SDM di sekolah juga sebaiknya melek teknologi. Menurut Steele, et al. (2019) menjelaskan bahwa aplikasi virtual yang diintegrasikan ke dalam pembelajaran akan dapat meningkatkan kemampuan kognitif dan kreatif peserta didik. Jariyah dan Tyastirin (2020) menjelaskan ada beberapa macam 
media online yang bisa digunakan dengan maksimal pada saat pembelajaran daring seperti saat ini misalnya Youtube, Telegram, WhatsApp, Schoology, Zoom meeting, Google Classroom, Kaizala, PodCast dan Teamlink. Berbagai media online ini bisa digunakan sesuai dengan kebutuhan belajar. Misalnya, media Whatsapp lebih disukai saat pembelajaran online saat ini, dengan alasan lebih minim dalam menghabiskan kuota. Dengan demikian, sebagai pendidik, hendaknya lebih mampu mengetahui media online apa saja yang bisa digunakan selama pembelajaran, sehingga lebih mudah menentukan mana yang tepat untuk digunakan selama pembelajaran dan tidak menyulitkan mahasiswa.

2. Memaksimalkan kreativitas pendidik: Dibalik banyaknya media online yang tersedia, pendidik juga perlu memaksimalkan kreativitasnya dalam menyajikan materi pelajaran. Hal tersebut dapat dilakukan dengan menyediakan media pembelajaran yang inovatif misalnya video pembelajaran, atau tutorial praktikum yang bisa ditiru oleh peserta didik dan dapat dikerjakan di rumah. Menggunakan metode-metode pembelajaran yang lebih bervariasi agar peserta didik tidak merasakan pembelajaran yang monoton dan hal ini bisa menghindari kebosanan yang mungkin terjadi selama pembelajaran.

Dengan demikian, keberhasilan pembelajaran online nyatanya sangat bergantung pada komponen-komponen yang terintegrasi satu sama lain, misalnya antara pendidik, peserta didik, juga sumber belajar, serta teknologi yang digunakan dalam mendukung pembelajaran. Menurut Hermanto \& Srimulyani (2021) menyatakan bahwa pembelajaran online tidak hanya memberikan tugas atau kuliah online dari pendidik ke peserta didik. Model pembelajarannya yang hanya satu arah saja. Idealnya terjadi pembelajaran dua arah atau adanya interaksi antara peserta didik dan pendidik (sinkronus). 
Dibalik segala kendala dan kesulitan dalam pembelajaran online ada beberapa keuntungan yang dirasakan pendidik dan peserta didik dengan diterapkannya sekolah dari rumah dan diterapkannya model pembelajaran online adalah sebagai berikut: memiliki keleluasaan waktu dalam pelaksanaannya, mengurangi potensi penyebaran Covid-19 di lingkungan kampus dan sekolah, meningkatkan keberanian siswa dalam mengemukakan gagasan, berpendapat dan bertanya secara gratis, serta memberikan pengalaman model pembelajaran yang baru bagi pendidik dan peserta didik. Kesiapan dan motivasi yang baik dari pendidik untuk ikut serta dalam memajukan pengetahuan dan keterampilan dalam pembelajaran online berkontribusi untuk memajukan kualitas pendidikan (Duraku dan Hoxha, 2020).

\section{Daftar Pustaka}

Abidah, A., Hidaayatullaah, H., Simamora, R., Fehabutar, D., \& Mutakinati, L. (2020). The Impact of Covid-19 to Indonesian Education and Its Relation to the Philosophy of "Merdeka Belajar." Studies in Philosophy of Science and Education, 1(1), 38-49.

Duraku, Z.H. \& Hoxha, L. (2020). The Impact of Covid-19 on Education and on The Well-Being of Teachers, Parents, and Students: Challenges Related to Remote (Online) Learning and Opportunities for Advancing the Quality of Education. Hasan Prishtina: University of Prishtina.

Gikas, J., \& Grant, M. M. (2013). Mobile computing devices in higher education: Student perspectives on learning with cellphones, smartphones \& social media. Internet and Higher Education, 19, 18-26.

Hermanto, Y.B. \& Srimulyani, V.A. (2021). The Challenges of Online Learning During the Covid-19 Pandemic. Jurnal Pendidikan dan Pengajaran. 54 (1): 46-57. 
Jariyah, I.T. \& Tyastirin, E. (2020). Proses dan Kendala Pembelajaran Biologi di Masa Pandemi Covid-19: Analisis Respon Mahasiswa. Jurnal Penelitian dan Pengkajian Ilmu Pendidikan: e-Saintika, 4 (2): 183-196.

Khasanah, M.N., Ningrum, T., \& Aprilia, I.R. (2020). Analisis Kendala Mahasiswa Pendidikan Biologi Universitas Tidar Saat Pembelajaran Daring Di Masa Pandemi Covid-19. Nectar: Jurnal Pendidikan Biologi, 1 (2): 1-8.

Masiah, M., \& Primawati, S. (2021). Response of Biology Students toward Online Learning in the Covid-19 Pandemic Era. Prisma Sains: Jurnal Pengkajian Ilmu dan Pembelajaran Matematika dan IPA IKIP Mataram, 9(1), 114-121. doi: https://doi.org/10.33394/jps.v9i1.3856.

Putri, E.K., Ambarwati, R.A., Rahayu, D.A., \& Khaleyla, F. (2020). Biology Online Classes During Covid-19 Pandemic in Indonesia. International Joint Conference on Science and Engineering, Advances in Engineering Research, 196: 176-180.

Steele, P., Johnston, E., Lawlor, A., Smith, C., \& Lamppa, S. (2019). Arts-BasedInstructional and Curricular Strategies for Working with Virtual Educational Applications. Journal of Educational Technology Systems, 47(3), 411-432.

Wisacita, Miranti (2020). Tantangan Dan Peluang Proses Pembelajaran Biologi Di SMA Negeri 1 Polanharjo Klaten Dalam Masa Dan Pasca Pandemic Covid-19. Prosiding Seminar Nasional Pascasarjana UNNES. 


\title{
OPTIMALISASI PEMBELAJARAN DARING DI PERGURUAN TINGGI PADA MASA PANDEMI
}

\author{
Dr. Abdul Gafur Marzuki, S.Pd. M.Pd. ${ }^{2}$ \\ (UIN Datokarama Palu)
}

“Optimalisasi pembelajaran daring pada perguruan tinggi di masa pandemi menjadi harapan semua pihak bukan saja bagi institusi pendidikan tetapi juga bagi stakeholder dan seluruh masyarakat."

Sejak kemunculannya di Wuhan pada akhir tahun 2019, bagi seluruh bangsa-bangsa di dunia dan WHO telah mengumumkan Coronavirus Disease sebagai wabah di seluruh dunia mulai 12 Maret 2020. Indonesia juga tak luput dari dampak pandemi ini, bahkan pemerintah dan rakyat Indonesia hingga medio 2021 masih terus berjuang melawan Covid 19 varian Delta yang lebih mematikan dari varian sebelumnya. Berbagai upaya telah dilakukan oleh pemerintah Indonesia diantaranya adalah vaksinasi massal, penerapan Protokol Kesehatan 3M, physical distancing hingga kebijakan PSBB (Pembatasan Sosial Berskala Besar) dan PPKM (Perberlakuan Pembatasan Kegiatan Masyarakat).

Penerapan berbagai kebijakan ini berdampak terhadap berbagai aspek, baik aspek sosial, ekonomi, budaya maupun aspek pendidikan khususnya di tingkat perguruan tinggi.

\footnotetext{
${ }^{2}$ Penulis lahir di Palu, 11 Juli 1983, penulis adalah dosen UIN Datokarama Palu dalam bidang Pendidikan Bahasa Inggris dan Teknologi Pembelajaran. Penulis memperoleh gelar sarjana Pendidikan Bahasa Inggris di Universitas Tadulako (2008), gelar Magister Pendidikan Bahasa Inggris di Pascasarjana Universitas Tadulako (2010), Doktor Teknologi Pembelajaran di Universitas Negeri Malang (2014), dan Kursus Singkat Academic English, Academic Writing, dan Research Methodology di Universitas Leiden, Belanda (2016).
} 
Pemerintah Indonesia melalui Kemendikbud telah merilis Edaran terkait upaya pencegahan dan penanggulangan pandemi pada satuan pendidikan dan terhitung mulai tanggal 17 Maret 2020 diberlakukan belajar secara daring bagi peserta didik, tenaga pendidik dan kependidikan di satuan pendidikan melalui berbagai platform daring (Kementerian Pendidikan dan Kebudayaan Republik Indonesia, 2020). Pemberlakuan edaran ini bagi tenaga pendidik telah merubah metode pembelajaran dari semula tatap muka menjadi tatap maya atau dikenal dengan sebutan pembelajaran daring karena dilaksanakan secara daring atau online.

Dalam pelaksanaannya, pembelajaran daring membutuhkan perangkat telekomunikasi yang berbasis pada teknologi, informasi, dan komunikasi (Marzuki, 2019; Coman dkk., 2020; Silalahi, dan Hutauruk, 2020; Siregar dkk., 2021). Dalam pembelajaran daring dikenal ada dua macam model pembelajaran yakni model Sinkronus (Synchronous) dan Asinkronus (Asynchronous) (Yusuf dan Jihan, 2020; Dubey dan Pandey, 2020; Dhawan, 2020). Pembelajaran daring model Sinkronus adalah pembelajaran daring yang dilaksanakan secara langsung bertatap maya menggunakan aplikasi telekonferensi Zoom, Google Meet, Streamyard, Skype dan Webex, sedangkan pembelajaran daring model Asinkronus adalah pembelajaran daring yang dilaksanakan secara tidak langsung tetapi melalui pemberian tugas dan materi yang bisa diakses peserta didik kapanpun dan dimanapun meraka inginkan menggunakan aplikasi pembelajaran yang lazim dikenal dengan sebutan LMS (Learning Management System) seperti Canvas, Moodle, Schoology, Edmodo, dan Google Classroom.

Berdasarkan hasil observasi dan survei daring penulis, didapatkan data bahwa penggunaan aplikasi pembelajaran di masa pandemi ini belum sesuai dengan harapan. Didapatkan fakta bahwa dosen dan mahasiswa pada mulanya mengalami kesulitan dalam menggunakan aplikasi pembelajaran daring. 
A d a p u n k esulitan yang dialami adalah sebagai berikut: (1) kurangnya pengetahuan tentang penggunaan aplikasi pembelajaran daring; (2) begitu banyaknya ragam aplikasi pembelajaran daring yang tersedia sehingga membingungkan mereka untuk memilih aplikasi pembelajaran daring apa yang harus digunakan; (3) adanya keterbatasan fasilitas utama dan pendukung dalam pembelajaran daring seperti koneksi internet yang stabil, perangkat komputer, laptop dan smartphone.

Adapun aplikasi pembelajaran daring model Sinkronus yang paling banyak digunakan dalam pembelajaran di Perguruan Tinggi di Kota Palu adalah Zoom Meeting dan Google Meet. Sedangkan aplikasi pembelajaran daring model Asinkronus yang familiar digunakan dalam proses pembelajaran adalah Edmodo, Google Classroom, dan Whatsapp yang digunakan jika sebagian besar mahasiswa berada di daerah terpencil (selama pandemi dan pembelajaran daring, mahasiswa biasanya kembali kekampung halaman mereka).

Pemanfaatan google classroom sebagai salah satu aplikasi favorit yang dirancang khusus untuk pembelajaran menjadi solusi dari permasalahan pembelajaran daring selama pandemi. Google classroom memiliki fasilitas yang memudahkan pengguna seperti Google docs, drive, sheets dan slides untuk memudahkan proses pembelajaran berlangsung (Prastiyo dkk, 2018; Tinungki \& Nurwahyu, 2020). Dengan pemanfaatan aplikasi google classroom, dosen dapat membagikan materi ajar, tugas, penilaian tugas, informasi, serta feedback atau umpan balik kepada mahasiswa yang dilakukan secara daring (Prastiyo dkk., 2018).

Pada perguruan tinggi, berbagai hasil studi menunjukkan bahwa pemanfaatan Google Classroom dalam prose s pembelajaran telah memberikan kemudahan bagi dosen dan mahasiswa dalam pengelolaan tugas serta hasil kemandirian belajar mahasiswa meningkat signifikan 
(Rahmad dkk., 2019). Penerapan dan pemanfaatan Google Classroom dalam proses pembelajaran secara online/daring telah berkontribusi dalam membantu mahasiswa untuk memahami bahan ajar perkuliahan dengan mandiri, sistematis juga memberikan efek positif dalam meningkatkan hasil dan motivasi belajar (Alfina, 2020). Google Classroom merupakan platform pembelajaran daring terbaik yang dapat digunakan guru/dosen dan sangat ideal digunakan untuk siswa/mahasiswa (Iftakhar, 2016). Mahasiswa menunjukkan respon positif terhadap penggunaan Google Classroom dalam hal kemudahan penggunaan dan mengakses pembelajaran (Albashtawi dan Al Bataineh, 2020).

Selain Google Classroom, aplikasi lain yang paling banyak dimanfaatkan oleh dosen dan mahasiswa dalam pembelajaran daring adalah aplikasi Edmodo. Edmodo merupakan aplikasi pembelajaran yang dirancang menggunakan metode pengaturan kelas berdasarkan kelompok (Sofa, 2018; Silalahi, dan Hutauruk, 2020; Asfar dan Asfar, 2021). Edmodo sebagai sebuah aplikasi pembelajaran atau Learning Management System berfungsi seperti Moodle yang selama ini banyak digunakan, namun Edmodo lebih mudah diakses, ringan, cepat, dan sederhana penggunaannya (Dharmawati, 2017). Fasilitas yang tersedia di Edmodo juga memudahkan penggunanya untuk dapat saling berkomunikasi, bekerjasama, bertukar informasi terkait proses pembelajaran._Edmodo dapat memfasilitasi proses pembelajaran secara daring sehingga dapat mendekati proses pembelajaran tatap muka di kelas dimana terdapat juga kegiatan diskusi, tanya jawab, simulasi, pemberian tugas, kuis, dan penilaian. (Marlina dkk., 2021). Selain itu, manfaat lainnya adalah meningkatnya pengetahuan pendidik terkait keterampilan pemanfaatan aplikasi Edmodo yang pada akhirnya akan bermuara pada berkualitasnya proses pembelajaran di kelas, serta membantu 
pendidik dalam menciptakan proses pembelajaran daring maupun blended yang tidak monoton (Zutiasari dkk., 2021).

Optimalisasi pembelajaran daring pada perguruan tinggi di masa pandemi menjadi harapan semua pihak bukan saja bagi institusi pendidikan tetapi juga bagi stakeholder dan seluruh masyarakat. Adanya kerjasama dan dukungan dari seluruh pihak yang terlibat akan menjadi kunci suksesnya pembelajaran daring. Selain itu, ketersediaan fasilitas pendukung dalam pembelajaran daring, motivasi dan partisipasi aktif mahasiswa dalam proses pembelajaran daring juga menjadi faktor penentu optimalnya pelaksanaan pembelajaran daring di Perguruan Tinggi.

\section{Daftar Pustaka}

Albashtawi, A. H., \& Al Bataineh, K. B. (2020). The effectiveness of google classroom among EFL students in Jordan: An innovative teaching and learning online platform. International Journal of Emerging Technologies in Learning, 15(11), 78-88. https://doi.org/10.3991/IJET.V15I11.12865

Alfina, O. (2020). Penerapan Lms-Google Classroom Dalam Pembelajaran Daring Selama Pandemi Covid-19. Majalah Ilmiah METHODA, 10(1), 38-46. https://doi.org/10.46880/methoda.v10i1.537

Asfar, A. M. I. T., \& Asfar, A. M. I. A. (2021). The effectiveness of distance learning through Edmodo and Video Conferencing Jitsi Meet. In Journal of Physics: Conference Series (Vol. 1760, No. 1, p. 012040). IOP Publishing.

Coman, C., Țîru, L. G., Meseșan-Schmitz, L., Stanciu, C., \& Bularca, M. C. (2020). Online teaching and learning in higher education during the coronavirus pandemic: students' perspective. Sustainability, 12(24), 10367. 
Dharmawati, D. (2017). Penggunaan media e-learning berbasis Edmodo dalam pembelajaran english for business. Query Journal of Information Systems, 162722.

Dhawan, S. (2020). Online learning: A panacea in the time of COVID-19 crisis. Journal of Educational Technology Systems, 49(1), 5-22.

Dubey, P., \& Pandey, D. (2020). Distance learning in higher education during pandemic: challenges and opportunities. Int. J. Ind. Psychol, 8(2), 43-46.

Education and Social Sciences, 3(1), 12-18. http://jesoc.com/wpcontent/uploads/2016/03/KC3_35.pdf

Iftakhar, S. (2016). Google Classroom: What Works And How? Journal of

Kementerian Pendidikan dan Kebudayaan Republik Indonesia. (2020). Surat Edaran Menteri Pendidikan dan Kebudayaan Republik Indonesia Nomor 35952/MPK.A/HK/2020. Mendikbud RI, 1-2. https://www.kemdikbud.go.id

Marlina, M., Junedi, B., Nasrullah, A., \& Mustika, H. (2021). Optimalisasi Penggunaan Google Classroom pada Pembelajaran Matematika di Masa Pandemi Covid 19. JMM (Jurnal Masyarakat Mandiri), 5(3), 836-846.

Marzuki, A. G. (2019). Utilizing Recorded English Dialogues in Teaching English Word Stress to Islamic Higher Education Students in Indonesia. Jurnal Pendidikan Islam, 5(1), 53-64.

Prastiyo, W., Djohar, A., \& Purnawan, P. (2018). Development of Youtube integrated google classroom based elearning media for the light-weight vehicle engineering vocational high school. Jurnal Pendidikan Vokasi, 8(1), 53. https://doi.org/10.21831/jpv.v8i1.17356 
Rahmad, R., Adria Wirda, M., Berutu, N., Lumbantoruan, W., \& Sintong, M. (2019). Google classroom implementation in Indonesian higher education. Journal of Physics: Conference Series, 1175(1). https://doi.org/10.1088/1742-6596/1175/1/012153

Silalahi, T. F., \& Hutauruk, A. F. (2020). The Application of Cooperative Learning Model during Online Learning in the Pandemic Period. Budapest International Research and Critics Institute-Journal (BIRCI-Journal), 3(3).

Siregar, S. D., Melati, E., \& Wahyuni, S. (2021). Selfassessment Optimization Through WhatsApp Features for Increasing Students' Listening Comprehension. English Education: English Journal for Teaching and Learning, 9(01), 13-24.

Sofa, E. M. (2018). Islamic Values in Higher Education Students' Communication in Edmodo Learning Platform. Edukasia Islamika, 50-65.

Tinungki, G. M., \& Nurwahyu, B. (2020). The implementation of Google Classroom as the e-learning platform for teaching Non-Parametric Statistics during COVID- 19 pandemic in Indonesia. International Journal of Advanced Science and Technology, 29(4), 5793-5803.

Yusuf, B. N., \& Jihan, A. (2020). Are we prepared enough? A case study of challenges in online learning in a private higher learning institution during the Covid-19 outbreaks. Advances in Social Sciences Research Journal, 7(5), 205-212.

Zutiasari, I., Rahayu, W. P., Martha, J. A., \& Indarwati, R. A. A. (2021). Pemanfaatan E-Learning Network Edmodo Dalam Pembelajaran. Dedication: Jurnal Pengabdian Masyarakat, 87-94. 


\section{TANTANGAN GENERASI EMAS INDONESIA 2045 DITENGAH NEW NORMAL COVID-19 DALAM PERSPEKTIF PENDIDIKAN TINGGI}

Adhitya Rol Asmi, M.Pd. ${ }^{3}$

(Universitas Sriwijaya)

"Rencana pemerintah dalam menyongsong tahun 2045 sudah begitu siap, dengan masuknya covid-19, ini menjadi pertanyaan kembali dan Apakah ini akan dikaji kembali atau ada arah baru"

Dada tahun 2045 yang akan datang, kita mulai menghitung 1 usia kita mulai dari sekarang!!! anda sudah tau jawabannya, dan apakah anda masuk dalam usia produktif kerja pada tahun tersebut?. Ini bukan berbicara mengenai apakah saya masih hidup, masih sehat, tentang usia tua atau muda namun kita akan berbicara mengenai diri kita sendiri dan pendidik demi Negara Kesatuan Republik Indonesia (NKRI) dalam bersaing secara global dengan usia kemerdekaan 100 tahun atau 1 abad. Bukankah warga Negara yang baik adalah apa yang kita beri kepada Negara bukan sebaliknya, Melihat ini, Hartono (Hartono, 2020) mengatakan bahwa permasalahannya yakni, apa yang kita bisa menjawab pertanyaan tersebut dalam bentuk bela Negara dalam teori Hegel, Defending Country.

Melihat ungkapan di atas, maka inilah jawabannya, bonus demografi Indonesia. Hal ini disebabkan besarnya jumlah tabungan dari usia penduduk yang produktif sehingga bisa memacu pertumbuhan ekonomi dan investasi, yang

${ }^{3}$ Penulis lahir di Bedegung, 09 September 1987, penulis adalah Dosen Universitas Sriwijaya dalam bidang ilmu Pendidikan Sejarah, penulis menyelesaikan gelar sarjana Pendidikan Sejarah di Universitas Sriwijaya (2009), Magister Pendidikan diselesaikan di Universitas Pendidikan Indonesia (2013) 
lazim dikenal sebagai jendela kesempatan atau windows of oppprtunity (Jati, 2015: 2). Pada tahun 2021 ini merupakan periode bonus demografi direntangan tahun 2015-2035 dengan indicator angka ketergantungan atau dependency ratio antara $0,4-0,5$ yang berarti pada 100 orang akan menanggung 40-50 orang usia tidak produktif. Usia produktif rentangan 15-65 tahun inilah yang diharapkan bisa memacu perekonomian Negara untuk menyambut satu abad Indonesia (Falikhah, 2017: 5). Hal ini dikuatkan oleh pernyataan dari United Nations dalam Maryati (2015:125) yang mengatakan bahwa Indonesia akan menikmati bonus demografi (demographic devident) pada periode tahun 2020-2030 (Maryati, 2015: 125).

Pendidikan sebagai wadah terbaik dalam mempersiapkan agen perubahan bangsa dan menjaga keberlanjutan suatu Negara melalui pembentukan kepemimpinan yang memiliki karakter, prilaku dan sikap mencerminkan kepribadian bangsa dengan salah satunya yakni perluasan akses ke perguruan tinggi (Rokhman dkk, 2014: 1161). Dalam perguruan tinggi ada dua prioritas penganggaran, pertama aksesibilitas, relevansi, mutu, dan kesetaraan gender. Kedua, penambahan gelar doktor agar bisa mengajarkan dan mendidik mahasiswa menjadi tenaga yang professional dengan siap masuk dunia kerja dan membuka lapangan pekerjaan (Darman, 2017: 83). Hal ini sedang dilakukan oleh pemerintah dengan menyediakan beasiswa yang dikelola oleh Lembaga Penyelenggara Dana Pendidikan (LPDP) dan diterapkannya kurikulum merdeka belajar.

Menjadi tantangannya adalah, pada awal tahun 2020, Indonesia dan semua negara di dunia mengalami guncangan berat karena virus corona atau Covid-19. Setelah melewati masa yang panjang karena adanya karantina wilayah di Indonesia yang dikenal Pembatasan Sosial Berskala Besar (PSBB) atau Pemberlakuan Pembatasan Kegiatan Masyarakat (PPKM) membawa 
kebiasaan baru bagi masyarkat Indonesia yang dikenal new normal atau normal baru yang artinya kehidupan dimana manusia selalu dihadapkan adanya ancaman Covid19 (Muhyiddin, 2020: 247).

Hal ini juga berdampak dalam bidang pendidikan terutama pendidikan tinggi, seperti dosen dan mahasiswa akan lebih terbiasa dengan pembelajaran jarak jauh yang untuk menggunakan platform online seperti zoom dan elearning untuk proses belajar mengajar, karena itu akan tumbuh banyak aplikasi pendidikan yang lebih inovatif untuk membuat belajar online semakin mudah dan menyenangkan (Paramita dkk, 2020: 58), namun itu akan mengancam karena Pendidikan tinggi adalah pendidikan terakhir menyiapkan peserta didik sebelum mereka kembali kemasyarakat dengan gelar sarjananya. Melihat situasi covid19 seperti sekarang ini yang sudah berjalan memasuki 2 tahun (4 semester), membuat mahasiswa semester akhir menjadi sarjana "covid" karena new normal (online), mulai usul judul, penggarapan skripsi, pengambilan data penelitian, melakukan skripsi secara online, sidang dan wisuda secara online, sedangkan mahasiswa angkatan 2020, mereka belum merasakan suasana kampus sedangkan saat ini mereka masuk semester 3, apalagi jika kita melihat mahasiswa yang mengambil program magister, artinya mereka bisa selesai tanpa sama sekali merasakan suasana kampus seperti normalnya.

Bila kita melihat dari proses belajar pembelajaran masa covid-19, maka akan bertentangan dengan teori belajar. Sudut pandang teori belajar, seperti kinestetik yang belajar menggunakan banyak keterlibatan seperti menyentuh, bergerak dan berkerja dengan berbagai indera (Papilaya, 2016: 59). Wang dan Peck (2013) dalam Ariani (2019:105) mendeskripsikan profil tentang keterlibatan ini, mahasiswa akan berhasil secara akademik melalui prestasi belajar dan kesehatan mental melalui keseimbangan 
emosional baik secara kognitif dan afektif sehingga menjadi pembelajaran yang bermakna bagi mahasiswa

Menurut David Ausubel dalam Rahma (2013:44), pembelajaran bermakna adalah dimana mahasiswa bisa mengaitkan informasi baru ke dalam memori kognitifnya yang meliputi konsep, fakta, dan generalisasi yang diingat dan dipelajari oleh mahasiswa. Penerimaan informasi berupa ide ataupun gagasan terjadi secara bersamaan dengan apa yang sudah ia dapatan dengan yang baru ia dapatkan (Harefah, 2013: 45).

Melihat rencana pemerintah dalam menyongsong tahun 2045 sudah begitu siap, dengan masuknya covid-19, ini menjadi pertanyaan kembali dan Apakah ini akan dikaji kembali atau ada arah baru. Memang kita mengetahui pemerintah melakukan kebijakan Merdeka Belajar Kampus Merdeka (MBKM) dimana universitas merombak kurikulumnya agar bisa menyesuaikan dengan konsep magang atau pertukaran mahasiswa baik di dalam universitas sendiri maupun antar kampus. Namun hal ini terasa percuma dikarenakan tetap sebagian besar dilakukan secara online atau daring, sehingga apa yg didapatkan oleh mahasiswa tidak bisa $100 \%$ karena mereka tidak bisa merasakan langsung seperti yang dikatakan oleh David Ausubel dan gaya belajar kinestetik. Hal ini juga akan mengancam karakterisik mahasiswa yang diharapkan lebih berkarakter terutama karakter religius dan nasionalisme melalui ideology pancasila. Karater inilah yang menjaga keutuhan dan kemajuan NKRI. 


\section{Daftar Pustaka}

Ariani, L. (2019). Keterlibatan Siswa (Student Engagement) Di Sekolah Sebagai Salah Satu Upaya Peningkatan Keberhasilan Siswa Di Sekolah. Prosiding Seminar Nasional \& Call Pape, Banjarmasin: 13 April 2019. Hal 103-110.

Darman, R. A. (2017). Mempersiapkan generasi emas indonesia tahun 2045 Melalui Pendidikan Berkualitas. Edik Informatika, 3(2), 73-87.

Falikhah, N. (2017). Bonus Demografi Peluang dan Tantangan Bagi Indonesia. Alhadharah: Jurnal Ilmu Dakwah, 16(32).

Harefah, Amin Otoni, dkk (2013). Peradaban Humanis dalam Lintasan Sejarah Islam. Sumatera Utara: Universitas Dharmawangsa Medan.

Hartono, Dwi. (2020). Fenomena Kesadaran Bela Negara di Era Digital dalam Perspektif Ketahan Nasional. Jurnal Kajian Lemhanas RI, (2020), 8 (1), 15-34

Jati, W. R. (2015). Bonus Demografi Sebagai Mesin Pertumbuhan Ekonomi: Jendela Peluang atau Jendela Bencana di Indonesia. Populasi, 23(1), 1-19. Doi: https://doi.org/10.22146/jp.8559

Kementerian Pendidikan dan Kebayaan Republik Indonesia. 2017. Peta Jalan Generasi Emas Indonesia 2045. Kementerian Pendidikan dan Kebudayaan Republik Indonesia, Jakarta.

Maryati, S. (2015). Dinamika pengangguran terdidik: tantangan menuju bonus demografi di Indonesia. Economica: Jurnal Program Studi Pendidikan Ekonomi STKIP PGRI Sumatera Barat, 3(2), 124-136.

Muhyiddin, M. (2020). Covid-19, New Normal, dan Perencanaan Pembangunan di Indonesia. Jurnal Perencanaan Pembangunan: The Indonesian Journal of 
Development Planning, 4(2), 240-252.Doi: 10.36574/jpp.v5i1.181

Paramita, I. B. G., \& Putra, I. G. G. P. A. (2020). New Normal Bagi Pariwisata Bali Di Masa Pandemi Covid 19. Pariwisata Budaya: Jurnal Ilmiah Agama Dan Budaya, 5(2), 57-65. Doi: http://dx.doi.org/10.25078/pba.v5i2

Papilaya, J. O., \& Huliselan, N. (2016). Identifikasi gaya belajar mahasiswa. Jurnal Psikologi, 15(1), 56-63.

Rokhman, F., Hum, M., \& Syaifudin, A. (2014). Character education for golden generation 2045 (national character building for Indonesian golden years). Procedia-Social and Behavioral Sciences, 141, 11611165. 


\title{
PEMASARAN DIGITAL SEBAGAI TANTANGAN, PELUANG DAN SOLUSI BISNIS PERTUMBUHAN EKONOMI UMKM DI MASA PANDEMI COVID-19
}

\author{
Irawati, S.E.,M.E.Sy ${ }^{4}$ \\ (Universitas Muhammadiyah Bandung)
}

\begin{abstract}
"Efek pendemi ini mengharuskan masyarakat lebih cerdas dalam mencari celah bisnis sebagai solusi usaha, dan salah satu bisnis yang menjanjikan dan diuntungkan dari dampak pandemi ini adalah bisnis digital"
\end{abstract}

$\mathrm{V}$

irus corona merupakan penyakit menular yang disebabkan oleh sindrom pernapasan akut (Sars-CoV-2) yang pertama kali ditemukan di provinsi Wuhan, China. Virus ini membawa pengaruh significan pada semua sektor mulai dari sektor ekonomi, pariwisata, kesehatan, ketenagakerjaan, keagaamaan, sosial, politik dan berbagai sektor lainnya dan dampak penyebaran virusnya dirasakan disemua negara tidak terkecuali Indonesia. Tidak ada yang tau kapan virus corona ini akan hilang dan juga tidak dapat dipastikan apakah virus akan benar-benar hilang atau akan menjadi endemi virus yang akan tetap ada disekitar kita. Saat ini masyarakat dihadapkan pada situasi harus dapat beradaptasi dengan virus ini, seperti halnya menghadapi virus-virus yang lain (Hiv, cacar, influensa, dengue, ebola, dll). Namun bagian

${ }^{4}$ Penulis lahir di Pariaman, 16 Mei 1973, penulis merupakan Dosen di Fakultas Agama Islam, pada Prodi Ekonomi Syariah, Universitas Muhammadiyah Bandung, Penulis menyelesaikan Gelar Sarjana Ekonomi di Prodi Manajemen Keuangan Dan Perbankan, INABA Bandung (1999). Gelar Magister Ekonomi Syariah diselesaikan di Prodi Ekonomi Syariah, Universitas UIN Sunan Gunung Djati Bandung (2015), dan sekarang penulis sedang melanjutkan Pendidikan Doktoral di Fakultas Hukum Islam, Prodi Ekonomi Syariah di Universitas UIN Sunan Gunung Djati Bandung. 
terpenting dalam kondisi saat ini adalah melakukan berbagai usaha pencegahan, agar penyebaran virus dapat diminimalisir dan semua aktivitas bisa berjalan kembali sebagaimana mestinya.

Salah satu usaha pencegahan penyebaran virus yang dilakukan adalah jarak fisik dengan orang lain (physical distancing) dan pembatasan kegiatan sosial guna menghindari terjadinya keramaian (social distancing). Dalam sektor ekonomi penerapan aturan physical social distancing ini memberi dampak pada hampir semua jenis usaha, terutama usaha yang mengandalkan keramaian seperti (pertunjukan/konser, pariwisata, usaha retail, hotel, tranportasi, tempat permainan anak dll), juga usaha property, leasing, salon, spa, rental, dan hampir semua usaha dari skala kecil maupun besar yang terpuruk karena pandemi ini. Pernyataan diatas didukung oleh jurnal Siti Indayani dan Budi Hartono yang mengatakan pertumbuhan ekonomi Indonesia mengalami penurunan sebesar 2,41\% sebagai dampak dari wabah virus corona, sehingga hal tersebut berakibat pula pada tingkat defisit anggaran negara yang mengalami kenaikan (Indayani,Siti., Hartono, Budi :2020). Turunnya pertumbuhan ekonomi menyebabkan naiknya tingkat pengangguran karena ketidakberdayaan pemilik usaha dalam melanjutkan produktivitas laju usahanya, pemutusan hubungan kerja oleh pemilik usaha menjadi pilihan yang harus mereka ambil untuk mengurangi beban operasional perusahaan, dan tidak cukup sampai disitu berdasarkan data Otoritas Jasa keuangan, pada semester 1 bulan Maret 2021 jumlah penduduk miskin Indonesia terus bertambah menembus angka 27,54 juta jiwa, (BPS: 2021).

Namun dampak bukan hanya tentang kerugian tapi juga dapat menjadi suatu tantangan bahkan peluang yang diharapkan dapat menjadi solusi sehingga mampu memberi keuntungan bagi pertumbuhan ekonomi. Dalam Islam setiap muslim diajarkan agar tidak berputus asa dalam menghadapi cobaan, kita harus tetap yakin bisa mencapai apa yang 
terbaik sesuai dengan yang diharapkan, seperti yang terdapat pada QS. Yusuf: 87 dibawah ini:

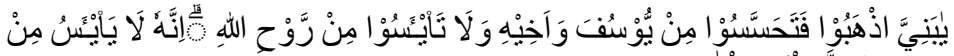

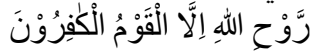

87. Hai anak-anakku, Pergilah kamu, Maka carilah berita tentang Yusuf dan saudaranya dan jangan kamu berputus asa dari rahmat Allah. Sesungguhnya tiada berputus asa dari rahmat Allah, melainkan kaum yang kafir"

Efek pendemi ini mengharuskan masyarakat lebih cerdas dalam mencari celah bisnis sebagai solusi usaha, dan salah satu bisnis yang menjanjikan dan diuntungkan dari dampak pandemi ini adalah bisnis digital, karena physical social distancing yang diterapkan oleh pemerintah mau tidak mau merubah perilaku konsumen dalam memenuhi kebutuhannya dari offline menjadi online. Peluang ini dapat menjadi solusi bagi semua pelaku usaha, salah satunya adalah UMKM,yang merupakan usaha paling terkena dampak pandemi. UMKM berdasarkan UU No 20 Tahun 2008 adalah (Ojk : 2017):

Kegiatan usaha yang mampu memperluas lapangan kerja dan memberi pelayanan ekonomi secara luas kepada masyarakat, dan dapat berperan dalan proses pemerataan dan peningkatan pendapatan masyarakat, mendorong pertumbuhan ekonomi, dan berperan dalam mewujudkan stabilitas nasional

Sampai saat ini baru sebagian kecil UMKM yang mempraktekan digital marketing dalam bisnisnya, karena kurangnya pengetahun mereka terhadap digital marketing dan e-commerce. Digital (online) merupakan cara untuk menarik minat pelanggan yang paling efektif yang merupakan bagian dari promosi, digital marketing terdiri dari pemasaran interaktif dan terpadu yang menjadi wadah yang dapat memudahkan bertemunya produsen, perantara pasar dan calon konsumen. Produsen dapat memastikan produknya mudah ditemukan karena calon konsumen 
dengan mudah dapat mengakses brand/produk yang mereka minati tanpa batas ruang dan waktu, selain itu juga menjadi wadah infomasi untuk mengetahui apa yang konsumen perlukan/butuhkan sehingga peluang bagi produsen untuk mengenalkan, menyediakan, memasarkan dan menjual produknya ke ranah digital, bahkan dari tahun 2014 jumlah iklan yang dipasarkan melalui internet sudah mengalahkan iklan yang ada di televisi.

Menurut Eko Nur Syahputro, pada data www.internetworldstats.com penyumbang pengguna internet terbanyak di dunia adalah Asia (50\%), lebih tinggi dari benua Eropa atau bahkan Afrika yang hanya 11,5\% sehingga benua Asia menjadi incaran raksasa internet seperti google, facebook, twiter untuk mengembangkan pangsa pasarnya di Asia (Syahputro,Eko Nur.:2020) dan berdasarkan hasil survey APJII (Asosiasi penyelenggara internet Indonesia) jumlah pengguna internet di Indonesia hingga kuartal II naik menjadi 196,7 juta pengguna atau $73,7 \%$ dari populasi penduduk Indonesia, (APJII:2000), banyaknya pengguna internet dan juga ditunjang beragam pilihan platform ( youtube, facebook, Instagram, line, linkedin, email, dll ) menjadi peluang untuk meningkatkan penjualan bagi pelaku usaha UMKM, bahkan untuk pengusaha pemula apabila belum memiliki keberanian untuk memasarkan produk sendiri juga dapat memulai usaha dengan cara bekerjasama atau membeli waralaba (franchise) yang telah memiliki strategi digital marketing yang baik yang dapat menjamin keberlangsungan usaha yang mereka dipilih.

Kehadiran UMKM diharapkan mampu berperan dalam meningkatkan pertumbuhan ekonomi dengan menciptakan lapangan pekerjaan dan salah stau peran pemerintah dalam mendukung UMKM seperti yang disampaikan oleh Menteri Perindustrian Agus Gumiwang Kartasasmita yaitu dengan program E-Smart IKM yang bertujuan untuk memacu daya saing dan memperluas akses pasar, (Kemenperin: 2021). Namun untuk hasil yang lebih maksimal, perlu adanya 
support yang menyeluruh dari pemerintah dan lembaga terkait lainnya agar pelaku usaha lebih melek teknologi melalui peningkatan sosialisai digital serta pelatihan teknologi informasi dan komunikasi atau hal-hal lain yang dapat memberi solusi nyata dalam peningkatan usaha. Selain itu sebagai pelaku usaha juga harus memahami dan mempelajari cara-cara untuk meningkatkan omzet penjualan, salah satunya seperti yang dikemukann oleh Andi gunawan chakti, tentang peningkatan omzet dengan strategi digital marketing yang kuat dan efektif yaitu: (Chakti, Andi Gunawan : 2019), yaitu: 1. Share, membuat konten menarik sehingga audiens tertarik untuk share konten anda kepada seluruh jaringan sosial media (Facebook, Instagram, Twitter, WhatsApp, dll), 2. Real Time Publish, membuat konten yang fresh atau baru agar audiens lebih mendalami informasi yang anda berikan dan tak lupa memberikan respon komentar, ulasan, komplain dari audiens secepat mungkin, 3. Berikan edukasi bukan hardselling, memberikan pengetahuan, mengedukasi pasar dan calon pelanggan sehingga menimbulkan rasa percaya audiens terhadap brand kita, 4 . Berikan hiburan, bukan hanya iklan promosi, agar menambah nilai konten sekaligus memberikan edukasi terhadap promosi kita, 5. Multi Channel Platform, buat kehadiran digital berada diberbagai channel (IG, FB,Twitter,Youtube, Blog, dll), 6. Konten Multimedia utamakan visual, karena audiens akan lebih tertarik pada konten visual dibandingkan audio atau text saja, 7 . Berfikirklah sebagai penerbit/wartawan, dengan membuat berita yang membuat pembaca menarik untuk membukanya, 8. Tentukan market pasar anda, membuat strategi sosial media sesuai dengan target pasar, 9. Listen, membuat suatu sistem yang menampung masukan audiens, dll. 


\section{Daftar Pustaka}

APJII, Survey Pengguna Internet.2020, Buletin APJII

Badan Pusat Statistik. 2021. Jumlah Penduduk Miskin Menurut Provinsi (Ribu Jiwa), 2020-2021, dikutip 17/8/2021

Chakti, Andi Gunawan. 2019. The book Of Digital Marketing. Celebes Media Perkasa.

Indayani, Siti., Hartono Budi. 2020. Analisis Pengangguran dan Pertumbuhan Ekonomi sebagai Akibat Pandemi Covid-19.Jurnal Ekonomi dan Manajemen, Universitas Bina Saranan Infomrmatika. Volume 18 No. 2 September 2020

Kemenperin, 2021. Strategi Kemenperin Percepat Target 6,1 Juta UMKM Go. Digital.kemeninfo.go.id

OJK, Undang-Undang Nomor 20 Tahun 2008 Tentang Usaha Mikro, Kecil, dan Menengah. : 2017, dikutip 17/8/2021

Syahputro, Eko Nur.2020. Melejitkan Pemasaran UMKM Melalui Media Sosial. Gresik Jawa Timur: Caremedia. 


\title{
PENDIDIKAN BERBASIS KELUARGA (TANTANGAN DI ERA COVID-19)
}

\author{
Khairuddin Hasan, M.Pd ${ }^{5}$ \\ (STAIN Teungku Dirundeng Meulaboh)
}

"Pendidikan berbasis keluarga adalah hal mutlakyang harus diterapkan bersama-sama demi kualitas hidup anak yang lebih cemerlang pada masa yang akan datang"

Pendidikan adalah kegiatan yang kompleks. bersinergi. Unsur yang terlibat mulai dari pemerintah, lembaga pendidikan, masyarakat, dan keluarga. Keluarga sebagai komunitas masyarakat yang paling kecil memiliki peran yang sangat menentukan bagi ketercapaian tujuan pendidikan. Prinsip-prinsip moral yang diterima oleh anak di lingkungan keluarga sangat berguna saat mengenyam pendidikan di lembaga formal. Karakter yang ditanamkan oleh orang tua akan menjadi bekal anak saat mengalami langsung proses pembelajaran di sekolah.

Menurut KBBI, keluarga adalah satuan kekerabatan yang sangat mendasar dalam masyarakat. Unsur minimal dalam keluarga adalah ayah, ibu, dan anak. Namun secara lebih luas, keluarga juga bermakna hubungan kekerabatan dalam komunitas terkecil di masyarakat yang saling membantu dan melindungi tanpa batasan waktu dan tempat. Jadi komponen

${ }^{5}$ Penulis lahir di Sungai Paham, 17 Agustus 1993. Penulis merupakan Dosen STAIN Teungku Dirundeng Meulaboh dalam bidang Pendidikan Agama Islam. Penulis menyelesaikan gelar Sarjana Pendidikan Islam di IAIN Sumatera Utara (2014) dan gelar Magister Pendidikan (2017) di UIN Sumatera Utara. 
keluarga juga bisa melibatkan kakek, nenek, paman, bibi, keponakan, dan sebagainya.

Pada saat pandemi covid-19 melanda Indonesia, maka dunia pendidikan langsung mengubah "wajahnya". Pembelajaran yang dulunya berjalan secara tatap muka di ruang kelas, berganti menjadi pembelajaran jarak jauh atau daring. Kebijakan tersebut diambil untuk menyelamatkan jiwa siswa, guru, dan pelaku pendidikan lainnya. Dampaknya juga terasa nyata bagi seluruh keluarga. Ayah dan ibu yang biasanya hanya bekerja untuk menghidupi anak-anak, maka suka atau tidak juga harus mendampingi anak pada saat belajar daring. Kesulitan anak dalam memahami materi pembelajaran juga dirasakan langsung oleh orang tua. Orang tua harus selalu siap membantu anak menyelesaikan tugasnya, atau bahkan tugas tersebut dikerjakan langsung oleh orang tua. Serba-serbi keseruan dan kesulitan orang tua dalam menemani anak belajar menjadi cerita baru. Banyak orang tua yang mengeluh, namun ada juga yang bersyukur. Banyak kritikan yang diarahkan ke guru, sekolah dan pemerintah. Ada juga yang menerima kenyataan bahwa tidak ada pihak mana pun yang menginginkan situasi tersebut. Orang tua terkesan kaget saat "terpaksa" berhadapan dengan aktivitas belajar anaknya sendiri.

Patut diduga, bahwa reaksi-reaksi tersebut bermula dari kekeliruan orang tua dalam memahami peran keluarga dalam pendidikan. Ada anggapan bahwa pada saat anak diserahkan oleh orang tua kepada lembaga pendidikan tertentu, maka peran orang tua menjadi berkurang atau bahkan hilang sama sekali. Seakan-akan, pendidikan anak adalah tanggung jawab orang tua yang dapat dialihkan. Dampaknya, sebagian orang tua menjadi apatis terhadap problem pendidikan anaknya sendiri. Guru dianggap bertanggung jawab penuh menyelesaikan masalah belajar anak. Campur tangan dari orang tua dinilai sekedar "bonus" saja. Sehingga pada saat situasi berubah seperti saat ini, orang tua "kaget" dan terkesan bingung mengambil tindakan yang tepat. 
Secara mendasar, peran keluarga dalam proses panjang pendidikan anak sangat penting dan tidak bisa tergantikan. Keluarga adalah tempat pertama bagi anak dalam belajar serta mengenal dirinya dan dunia. Nilai-nilai yang ditanamkan oleh keluarga akan terpatri jauh di jiwa anak dan menjadi pegangan dalam mengarungi gelombang kehidupan.

Pendidikan berbasis keluarga penting untuk diperhatikan demi mengembalikan peran sejati keluarga dalam pendidikan. Tanpa peran dan kepedulian keluarga, anak berpotensi kehilangan tempat untuk mengembangkan dirinya. Ada banyak riset yang menunjukkan bahwa degradasi moral pada anak dan remaja salah satunya disebabkan oleh kurangnya peran keluarga.

Berdasarkan penelitian bahwa karakter anak dapat dibentuk dengan baik dengan pendidikan berbasis keluarga (Fiina TN, Ashif AZ, 2020: 1-20). Meskipun pada saat pandemi Covid-19 interaksi siswa dengan guru berkurang, sehingga pembinaan karakter dapat terhambat namun hal tersebut dapat ditanggulangi dengan peran keluarga. Ini menjadi salah satu indikator betapa pentingnya keluarga bagi anak, khususnya dalam pendidikan.

Secara umum, fungsi keluarga menurut Sudjana (Unang.W, 2012:4-5) adalah:

1. Fungsi biologis, yang bertujuan untuk memelihara kesehatan jasmaniah anggota keluarga, memenuhi kebutuhan seksual antara pasangan suami istri, dan untuk memperoleh keturunan;

2. Fungsi edukatif, untuk menumbuhkembangkan keluarga sebagai wahana pendidikan pertama dan paling utama. Dengan fungsi ini terkondisi keluarga yang saling membelajarkan di antara anggota keluarganya sehingga terwujud keluarga gemar membaca dan gemar belajar, atau keluarga berbudaya belajar;

3. Fungsi religis, berkaitan dengan kewajiban orang tua, sebagai pendidik utama, untuk menciptakan iklim 
keagamaan dalam kehidupan keluarga. Orang tua mempunyai peran utama dalam mengenalkan, membimbing, memberi teladan dan melibatkan anakanak dan anggota keluarga lainnya dalam memahami dan melaksanakan ajaran-ajaran agama dalam kehidupan sehari-hari;

4. Fungsi kasih sayang, menyiratkan bahwa interaksi dalam keluarga dibina atas dasar hubungan emosional dan spiritual yang kondusif untuk tumbuh kembangnya silih asih, silih asah, dan silih asuh. Orang tua menjadi cermin bagi anggota keluarga lainnya dalam interaksi intra keluarga ini. Hubungan orang tua dalam situasi mawaddah wa rahmah menjadi contoh yang baik bagi pengembangan kasih sayang bagi anggota keluarga lainnya;

5. Fungsi perlindungan (protektif), bertujuan untuk 1) mengembangkan potensi-potensi ketahanan mental dan fisik anak-anak dan anggota keluarga lainnya ke arah yang lebih baik, dan 2) menjaga, memelihara, dan menangkal anak-anak dan anggota keluarga lainnya dari pengaruh negatif yang datang dari luar lingkungan keluarga;

6. Fungsi sosialisasi, yang bertujuan untuk mempersiapkan anak-anak dan anggota keluarga lainnya menjadi anggota masyarakat yang baik yaitu berpartisipasi aktif dan kontributif dalam kegiatan sosial dan pembangunan, harmonis dalam hubungan intra dan antara keluarga, mengakui dan menghargai perbedaan, mencari dan menemukan titik-titik persamaan, serta membina kebersamaan dalam kehidupan bermasyarakat dan berbangsa di atas titik persamaan tersebut;

7. Fungsi ekonomi, memberi makna bahwa keluarga merupakan ekonomi. Aktifitasnya berkaitan dengan upaya mencari nafkah, membina dan mengembangkan usaha keluarga, perencanaan pendapatan dan 
pengeluaran biaya keluarga. Pada gilirannya, kegiatan dan status ekonomi keluarga dapat mempengaruhi harapan orang tua dan anak-anak terhadap masa depan kehidupan mereka;

8. Fungsi rekreasi, tidak menggambarkan harus adanya kemewahan dalam keluarga melainkan dengan mengkondisikan rumah tangga sehingga tumbuh suasana keluarga yang tenang, sakinah wa rahmah, damai, jauh dari ketegangan rohaniah, harmonis, dinamis dan kreatif;

9. Fungsi kepedulian, terhadap lingkungan, baik lingkungan sosial budaya maupun lingkungan alam. Kepedulian terhadap lingkungan sosial budaya bertujuan agar keluarga memperhatikan dan memberikan manfaat secara optimal kepada sesama manusia dan membina serta melestarikan budaya. Kepedulian terhadap lingkungan alam sekitar bertujuan supaya keluarga memahami, menyikapi secara positif, dan melestarikan sumber daya alam baik hayati dan non hayati maupun sumber daya buatan.

Sudjana menempatkan fungsi edukatif atau fungsi pendidikan menjadi fungsi kedua setelah fungsi biologis. Ini menunjukkan bahwa antara pendidikan anak dan keluarga ibarat 2 sisi koin yang tidak dapat dipisahkan. Anak begitu ketergantungan pada peran keluarga untuk mendidiknya. Hal ini sejalan dengan temuan Tin, Diah, Resti dan Eka bahwa peran keluarga dalam pendidikan sangat penting dan berdampak nyata. Keluarga dapat berperan dalam penanaman karakter mandiri, bertanggung jawab dan bekerja sama. Keluarga juga akan menjadi contoh bagi anak. Dan anak juga akan belajar banyak hal tentang kreativitas diri dari keluarganya (Tin.H, Diah.K, Resti.P, Eka.WL, 2020:213-227). Semuanya itu menjadi modal besar bagi anak dalam menjadi kehidupannya nanti. 
Sedangkan pada fungsi religis, kasih sayang, perlindungan, ekonomi, dan kepedulian, juga terdapat aspek pendidikan. Jika keluarga (khususnya orang tua) mampu menjadi teladan dalam menjalankan fungsi-fungsi tersebut, maka anak akan belajar dan menirunya pada kesempatan lain. Anak akan melihat bagaimana orang tua mereka menghadapi masalah dan menyelesaikannya, menghadapi tantangan hidup serta mampu melewatinya.

Pendidikan berbasis keluarga adalah hal mutlak yang harus diterapkan bersama-sama demi kualitas hidup anak yang lebih cemerlang pada masa yang akan datang. Pendidikan adalah kewajiban serta tanggung jawab keluarga pada anak. Dan pendidikan adalah hak anak yang harus diperoleh dari keluarganya. Pendidikan adalah proses panjang dan kompleks. Proses panjang pendidikan membutuhkan banyak peran dari berbagai pihak. Dan proses panjang tersebut akan ditentukan oleh pihak yang paling banyak dan sering berinteraksi dengan anak. Dan pastinya, keluarga lah yang menjadi faktor penentunya.

\section{Daftar Pustaka}

Herawati, Tin., Krisnatuti, Diah., Pujihasvuty, Resti., Latifah, Eka Wulida. 2020. Faktor-Faktor Yang Mempengaruhi Pelaksanaan Fungsi Keluarga di Indonesia. Jurnal Ilm. Kel. \& Kons, Vol. 13, No. 3. DOI: http://dx.doi.org/10.24156/jikk.2020.13.3.213

Nafisah, Fiina Tsamrotun., Az Zafi, Ashif. 2020. Model Pendidikan Karakter Berbasis Keluarga Perspektif Islam di Tengah Pandemi Covid-19. Ta'allum: Jurnal Pendidikan Islam, Vol. 8, No. 1. DOI: 10.21274/taalum.2020.8.1.1-20

Wahid, Unang. 2012. Peran Strategis Keluarga dalam Pendidikan Anak. Edukasi Islami: Jurnal Pendidikan Islam, Vol. 1, No. 2. DOI: http://dx.doi.org/ 10.30868/ei.v1i02.19 


\title{
OPTIMALISASI ETOS KERJA SEORANG PENDIDIK DALAM MENINGKATKAN EFEKTIVITAS BELAJAR MENGAJAR DI MASA PANDEMI
}

Tuti Nuriyati, M.Pd. ${ }^{6}$

(STAIN Bengkalis, Riau)

\begin{abstract}
"Pendidik yang telah memiliki etos kerja yang baik maka dalam sebuah pendidikan akan menjadikan sebuah proses belajar mengajar akan efektif dan efisiensi"
\end{abstract}

$\mathrm{P}$ endidik dalam sebuah lembaga pendidikan sangat utama dan sangat penting untuk menjalankan sebuah aktifitas belajar mengajar atau menghidupkan suasana lingkungan pendidikan. Pendidik yang profesional adalah pendidik yang memiliki empat kompetensi dasar yaitu; pertama kompetensi pedagogik, kemampuan seorang pendidik untuk mengelola suatu proses belajar mengajar, saling menghidupkan interaktif dalam sebuah pembelajaran, pedagogik ini menuntut seorang pendidik memahami setiap karakteristik dari seorang peserta didik, baik dari sikap, kemudian dari materi yang akan di sampaikan maupun dalam menguasai dunia belajar mengajar. Kedua Kompetensi kepribadian; kompetensi ini berkaitan dengan seorang pendidik, cerminan seorang pendidik yaitu memiliki sifat terpuji karena pendidik menjadi teladan untuk peserta didik, dan mampu dalam memberikan motivasi dan nasehat agar peserta didik memiliki attitude yang di harapkan. Ketiga Kompetensi

${ }^{6}$ Penulis lahir di Aceh, 18 Februari 1992, penulis merupakan dosen tetap STAIN Bengkalis, Riau, dalam bidang ilmu Pendidikan Islam, penulis menyelesaikan gelar sarjana dengan keilmuan Pendidikan Agama Islam di Universitas Islam Indonesia Yogyakarta pada tahun 2016, sedangkan gelar Magister dengan keilmuan Pendidikan Islam di Universitas Islam Indonesia Yogyakarta pada tahun 2018. 
profesional; kompetensi ini menuntut seorang pendidik untuk meningkatan keterampilannya atau kewajibanya agar tugas-tugas seorang pendidik terselesaikan dengan baik. Profesional dijelaskan bahwa pendidik mampu menguasai materi yang di ajarkan, sehingga fungsi dan tugas seorang pendidik terlaksana dengan semestinya dan dapat meningkatkan atau mencapai standar kompetensi yang telah di tentukan. Keempat Kompetensi sosial; pendidik harus mampu bersosial baik dalam lingkungan sekolah, maupun dalam lingkungan masyarakat karena dengan bersosial seorang pendidik dapat menemukan informasi berkaitan dengan sebuah pembelejaran atau peserta didik dan lain sebagainya yang berada dalam lingkungan pendidikan sehingga tidak menimbulkan prasangka negatif antara satu dengan yang lainnya. Seorang pendidik mampu menggunakan komunikasi yang baik ketika berbicara, cepat mengenali budaya sekolah atau budaya lingkungan masyarakat sehingga mudah dalam mengayomi SDM yang ada.

Pendidik adalah pilar pendidikan, keberhasilan sebuah pendidikan karena adanya seorang pendidik yang memiliki etos kerja yang baik. Seorang pendidik yang telah memiliki etos kerja maka yang terlihat dalam dirinya yaitu hal positif mampu membangun keharmonisan serta kefektifan dalam sebuah belejar mengajar karena memiliki rasa tanggung jawab, kerjasama serta semangat yang tinggi, tidak mementingkan kebutuhan diri sendiri akan tetapi mengkaji sebuah fenomena kemudian di analisa lalu di simpulkan menjadi sebuah pembaharuan yang mendukung perkembangan pendidikan memiliki standar yang tinggi dan mampu mencapai persaingan di manca negara.

Seorang pendidik selama seluruh negara terutama di Indonesia di landa bencana pandemi covid 19 maka pendidikan memiliki tugas tersendiri dalam sistem belajar mengajar yang jauh berbeda dengan keadaan normal. Fasilitas pembelajaran selama pandemi covid 19 yaitu 
menggunakan pembelajaran jarak jauh yang alternatifnya menggunakan teknologi komputer dan internet. Pembelajaran jarak jauh ini menjadikan proses belajar mengajar memiliki kelebihan dan kekurangan. Kelebihan dari Pembelajarn Jarak Jauh yaitu pembelajaran bisa di laksanakan di mana saja tanpa adanya batas ruang dan waktu sedangkan kekurangannya minimnya akses jaringan telekomunikasi bagi peserta didik yang tinggal di wilayah pedesaan dan semua perekonomian peserta didik tidaklah sama sehingga tidak semua peserta didik yang mampu mengembang pendidikan melalui komputer dan hal tersebut menjadikan kendala dalam proses belajar mengajar.

Etos kerja seorang pendidik keadaan sekarang sangat memicu efektifitas belajar mengajar, karena pendidik di tuntut mampu mentranpormasikan sebuah pembelajaran yang efisien, mudah diterima dan dipahami oleh peserta didik. Hasil dari pengamatan di lingkungan pendidikan banyak orang yang sekarang ini belajar hanya ingin memiliki pekerjaan yang sesuai dengan kebutuhannya atau ada juga yang berpikiran bahwa dengan berpendidikan akan menjadi kaya serta agar lebih terkenal di lingkungannya. Dengan adanya hal tersebut maka pendidik memiliki tugas bagaimana pandangan yang demikian hilang dalam diri setiap individu, dan tanamkan dalam diri seseorang bahwa menuntut ilmu itu wajib bagi setiap muslim dan ilmunya bermanfaat bagi yang lainnya.

Ciri-ciri etos kerja pada seorang pendidik agar menyebabkan sebuah hasil yang baik meskipun mereka dalam sebuah lingkungan pendidikan, sebagai berikut;

1. Ikhlas; pendidik yang memiliki sifat ikhlas merupakan bentuk dari cinta kasih terhadap pekerjaannya dan semangat dalam menjalaninya tanpa mengharapkan sebuah imbalan yang besar. Ikhlas memiliki nilai yang tinggi untuk kepribadian seseorang, sifat ikhlas membersihkan hati seseorang yang memilikinya. 
2. Jujur; pendidik yang memiliki kejujuran maka hidupnya akan di tolong oleh Allah Swt tanpa ragu-ragu karena kehidupan ini moral yang baik salah satunya yaitu sebuah kejujuran baik terhadap diri sendiri maupun terhadap orang lain. Walau terkadang dalam sebuah lembaga pendidikan ada ketidak jujuran maka bagi seorang pendidik yang memiliki etos kerja yang baik maka kita batasi diri kita selalu melakukan perbuatan positif, hal ini bukan keterpaksaan akan tetapi panggilan hati seorang yang berpegang teguh pada Agama Allah Swt.

3. Disiplin (menghargai waktu); pendidik yang memiliki etos kerja yang seharusnya maka disiplin adalah hal yang sangat urgent untuk di tanamkan dalam diri dan diterapkan dalam lingkungan kerja, pendidik yang telah memilki kedisiplinan maka mampu mengatur waktu secara baik, dan mengerjakan sesuatu akan selesai dengan waktu yang diberikan. Karena fenomena dalam kehidupan semakin seseorang mempu melaksanakan disiplin dengan baik maka mereka banyak peluang untuk sukses dalam pekerjaannya.

4. Memiliki komitmen; pendidik yang memiliki komitmen untuk melaksanakan pekerjaannya dengan baik dan bertanggung jawab. Contohnya seorang pendidik selama pandemi maka mereka harus melaksanakan pembelajaran semaksimal mungkin dan mudah di pahami oleh peserta didik. mempertahankan prinsip meskipun banyak resiko yang dihadapi oleh pendidik. Akan tetapi pendidik harus memiliki kreatifitas dalam belejar mengajar dan tidak ada sifat putus asa dalam hidupnya. Pendidik yang memilki etos kerja yang tinggi maka mampu megendalikan emosinya secara efektif, memiliki komitmen seorang pendidik tidak melupakan kerjasamanya terhadap SDM lainnya. Pendidik menganggap bahwa adanya kerja sama maka sebuah pekerjaan akan terlesaikan dengan baik. 
Etos kerja seorang pendidik dalam meningkatkan proses belajar mengajar sangat di butuhkan karena pendidik yang belajar mengajar akan menghasilkan sebuah lulusan yang berguna dan ilmunya bermanfaat bagi orang lain di lingkungannya. Etos kerja pendidik di atur dalam sebuah sistem organisasi lingkungan pendidikan sehingga memiliki pemimpin yang di jadikan panutan. Maka produktivitas kerja berdasarkan kesepakatan yang di wajibkan pada seorang pendidik, untuk mencapai lulusan yang berkualitas.

Fenomena lingkungan sekarang banyak kita menemukan bahwa tinggi rendahanya sebuah etos kerja di pengaruhi oleh banyak faktor, antaranya pendapatan yang tidak sesuai dengan pekerjaan, gaya kepemimpin yang tidak memperhatikan staf, lingkungan kerja yang masing-masing memikirkan egoisme untuk mencapai kepentingan diri sendiri. Maka untuk meminimalisir hal tersebut seorang pemimpin harus memperhatikan kebutuhan material dan immaterial seorang pendidik, dan melakukan hal yang mampu meminimalkan permasalahan yang akan mungkin terjadi di lingkungan pendidikan. Dan bagi seoarang pendidik harus benar-benar memiliki ciri-ciri etos kerja yang baik dalam dirinya agar tidak mudah terpengaruh oleh lingkungan pekerjaan.

Namun seorang pendidik juga seorang manusia yang membutuhkan motivasi dan dorongan untuk menguatkan dirinya dalam menjalankan pekerjaannya dalam sebuah belajar mengajar maka seorang pendidik harus diperlakukan secara adil, fasilitas yang memadai untuk mentransformasikan sebuah pembelajaran serta di beri penghargaan bagi pendidik yang telah lama berkerja dengan semaksimal mungkin dan yang telah banyak menghasilkan prestasi dalam sebuah pembelajaran.

Pendidik yang telah memiliki etos kerja akan melakukan pekerjaan rajin dan mengutamakan kejujuran. Faktor internal dari etos kerja yaitu berasal dari diri sendiri yang hidupnya berserah diri kepada sang pencipta dan memiliki 
jiwa semangat mengabdi dan berbuatan untuk masyarakat membagi pengetahuannya kepada orang yang membutuhkan agar semakin banyak manusia yang menjalankan kehidupannya menurut syari'at yang telah ada dan tidak saling egoisme. Selain dari dalam diri sesorang juga faktor etos kerja dari eksternal yaitu, lingkungan kerja, kepemimpinan dan bayaran, namun bagi seorang pendidik memiliki panggilan jiwa dan keinginan dalam menyampaikan pengetahuan, wawasannya dan kemanusiannya. Sehingga dalam diri pendidik harus memiliki kekuatan spritual yang tinggi untuk membatasi suatu kejadian yang di luar kendali.

Pendidik yang telah memiliki etos kerja yang baik maka dalam sebuah pendidikan akan menjadikan sebuah proses belajar mengajar akan efektif dan efisiensi. Dan menghasilkan lulusan yang mampu mengubah dunia menjadikan sebuah pembelajaran yang harus terus dikembangkan dan di pelihara kemajuannya. Pengalamanpengalaman yang telah di lalui selama hidup atau belajar akan menjadikan sebuah pembelajaran menjadikan diri setiap individu menjadi lebih baik sesuai dengan tujuan telah ditetapkan. Sebuah lembaga pendidikan tidak lepas dari sebuah visi misi yang memajukan dunia pendidikan lebih baik.

Efektivitas belejar mengajar akan lebih baik jika setiap pendidik memiliki strategi atau model pembelajaran yang baru agar peserta didik menerima sebuah pembelajaran tidak monoton dan mudah di pahami. Masa pandemi banyak pendidik menggunakan aplikasi dalam sebuah pembelajaran sehingga dalam penyampaiannya mudah diterima dan di pahami oleh peserta didik, walau belajar tidak dilakukan dengan tatap muka akan tetapi pembelajaran tidak bisa terlepas begitu saja. Dunia sekarang membutuhkan seorang pendidik yang benar-benar memiliki etos kerja yang baik.tanpa harus banyak menuntut haknya. Menjadikan negara maju dalam dunia pendidikan maka harus di lebih memperhatikan seorang pendidik dalam etos kerjanya. 


\title{
MEMBANGUN KOMPETENSI SUMBER DAYA MANUSIA SEBAGAI UPAYA MENINGKATKAN PENDAPATAN EKONOMI PASCA PANDEMI COVID-19
}

\author{
Husni Awali, M.M. ${ }^{7}$ \\ (Institut Agama Islam Negeri Pekalongan)
}

"Masyarakat dalam mempertahankan ketahanan ekonomi tidak harus bergantung pada bantuan pemerintah tetapi dapat melaksanakan kegiatan usaha dengan berbagai media online sehingga pendapatan ekonomi tetap terjaga"

$\mathrm{M}$ ewabahnya Virus Covid-19 ke berbagai negara telah menjadi pandemi yang memberikan dampak luar biasa bagi negara, bangsa hingga berbagai sektor kehidupan masyarakat, tidak terkecuali sektor ekonomi baik dunia usaha maupun kehidupan masyarakat yang berdampak pada pendapatan ekonomi sebagai bagian dari kesejahteraan. Adanya Covid-19 banyak mengubah tatanan kehidupan sehingga menuntut kita untuk dapat beradaptasi dan mengikuti segala perubahan yang ada. Namun selain itu perlu adanya upaya untuk meningkatkan kapasitas diri sebagai cara pandang dalam mengatasi segala perubahan yang diakibatkan dari adanya pandemi. Untuk itu dalam berbagai elemen kehidupan tidak hanya siap dalam beradaptasi namun kita juga perlu meningkatkan kompentensi sebagai penyiapan sumber daya manusia yang handal dan memiliki

${ }^{7}$ Husni Awali, M.M. Lahir di Bekasi pada tanggal 29 September 1989. Saat ini sebagai Dosen di Fakultas Ekonomi dan Bisnis Islam, Institut Agama Islam Negeri Pekalongan. Mata kuliah yang pernah diampu antara lain Manajemen Sumber Daya Insani, Kewirausahaan, Teori Pengambilan Keputusan dan Pengantar Manajemen dan Bisnis. Pendidikan terakhir S2 Manajemen Sumber Daya Manusia di Universitas Mercu Buana Jakarta. 
kompetensi yang lebih untuk dapat menyesuaikan dengan segala tuntutan perubahan dari pandemi yang begitu banyak memberikan pengaruh terhadap ketahanan ekonomi masyarakat. tidak sedikit masyarakat yang kehilangan pekerjaan, dunia usaha yang mengalami gulung tikar hingga pada peningkatan kemiskinan yang terjadi karena adanya gejolak ekonomi yang disebabkan pandemi berkepanjangan yang membatasi pergerakan masyarakat dalam kegiatan ekonomi.

Untuk mempertahankan ketahanan ekonomi masyarakat memang perlu adanya upaya intervensi dari pemangku kepentingan yang dapat memberikan perlindungan sebagai pencegahan kemiskinan masyarakat. tetapi juga perlu adanya pembekalan kepada masyarakat agar memiliki cara hidup yang dapat menghasilkan nilai ekonomi melalui berbagai bentuk peningkatan kompetensi yang nantinya dapat dijadikan sebagai bekal diri dalam mempertahankan ketahanan ekonomi baik di lingkungan masyarakat maupun lingkungan terkecil dalam keluarga. Dalam kondisi keterbatasan saat ini memang menjadikan ekonomi masyarakat semakin terpuruk, selain adanya bantuan dari pemerintah, masyarakat pun perlu didorong untuk dapat melaksanakan kegiatan yang menghasilkan nilai ekonomi meski tidak berinteraksi secara langsung atau face to face. Tetapi dengan segala perkembangan teknologi yang ada kini menjadi cara hidup yang telah menjadikan suatu kebiasaan baru dengan mengandalkan kecanggihan teknologi. meski dengan keterbatasan kondisi dampak pandemi, kini masyarakat dalam mempertahankan ketahanan ekonomi tidak harus bergantung pada bantuan pemerintah tetapi dapat melaksanakan kegiatan usaha dengan berbagai media online sehingga pendapatan ekonomi tetap terjaga. Untuk itu perlu adanya upaya peningkatan kompetensi sumber daya manusia sebagai bekal dalam mempertahankan dan meningkatkan pendapatan ekonomi pasca pandemi covid-19 
agar perekonomian masyarakat kembali pulih dengan menganut cara hidup kebiasaan baru dari dampak pandemi:

1. Pengenalan Dunia Teknologi

Perkembangan teknologi kini semakin pesat dan memberikan kemudahan dalam berbagai aspek, begitu juga dalam kegiatan ekonomi kini banyak sektor usaha telah mengandalkan kecanggihan teknologi. Untuk itu pengenalan teknologi kepada masyarakat menjadi hal penting agar masyakarat kini melek akan perkembangan teknologi dan dapat mengambil kebermanfaatan yang positif dari adanya teknologi. Tidak sedikit masyarakat kita yang masih awam terhadap penggunaan teknologi, tetapi untuk dapat berkembang memang perlu adanya dorongan pihak terkait untuk mengenalkan teknologi agar masyarakat dapat menjalankan kegiatan yang menghasilkan nilai ekonomi dengan mudah seperti yang sudah dimulai oleh masyarakat luas dimana dimasa pandemi sudah banyak yang mengandalkan media online sebagai fasilitas dalam berwirausaha ditengah pandemi.

2. Pelatihan Digital Marketing

Adanya perkembangan teknologi telah memberikan manfaat bagi dunia usaha, kini tidak sedikit dunia usaha yang memasarkan produknya melalui media online. Salahsatunya dengan berkembangnya berbagai marketplace menjadi andalan kegiatan usaha baik industri rumah tangga hingga industri besar telah bergabung dalam marketplace yang ada sebagai wadah dalam memasarkan produknya. Hal ini telah menjadi cara yang sangat mudah dan bermanfaat ditengah pandemi dimana kegiatan usaha tetap berjalan meski banyaknya aturan atau kebijakan yang membatasi kegiatan masyarakat diluar, tetapi dengan adanya pemasaran produk dengan memanfaatkan cara digital marketing memberikan kebermanfaatan yang luar biasa sehingga masyarakat tetap memiliki penghasilan meski 
ditengah pandemi. Namun tidak semua pelaku usaha memahami bagaimana akses atau cara memanfaatkan digital marketing sepertihalnya bergabung pada marketplace. Untuk itu perlu adanya pelatihan digital marketing bagi pelaku usaha khusunya UMKM atau industri rumah tangga sebagai bentuk penyiapan dalam memulihkan ekonomi yang dijadikan sebagai peningkatan kompetensi sumber daya manusia pelaku usaha pasca pandemi covid-19.

3. Optimalisasi Penggunaan Media Sosial

Tidak hanya marketplace, penggunaan sosial media lainnya pun dapat dijadikan sebagai wadah dalam berbisnis sebagai upaya memulihkan dan meningkatkan pendapatan ekonomi pasca pandemi covid-19. Di masa pandemi kita sudah terbiasa mengandalkan kecanggihan media sosial dalam berbagai interaksi secara online. Untuk itu pasca pandemi cara ini dapat dijadikan sebagai adaptasi kebiasaan baru didalam kegiatan ekonomi. Optimalisasi penggunaan Media Sosial secara online seperti Instagram, facebook, Twitter, YouTube dan lainlain kini seakan menjadi wadah promosi dan memasarkan produk yang sangat diandalkan. Dengan kemudahan akses dan tidak memerlukan biaya mahal tetapi memiliki jangkauan yang sangat luas untuk dapat dikenal masyarakat. Untuk itu kita perlu melek akan media sosial dan mengoptimalkan kebermanfaatan dari media sosial yang kita miliki sebagai bentuk sarana dalam berbisnis dan dalam meningkatkan pendapatan ekonomi di pasca pandemi.

4. Pelatihan dan Pedampingan Potensi Daerah

Daerah yang kaya akan potensi maka perlu didorong dan dibentuk dengan sumber daya manusia yang handal dan memiliki kompetensi untuk mengelolanya. Untuk itu perlu adanya pelatihan penciptaan suatu produk dari potensi daerah. Dimana dengan melihat potensi yang 
dimiliki suatu daerah maka perlu dilakukan pendampingan terhadap sumber daya manusia yang ada untuk dapat menjadikan potensi daerah memiliki nilai jual dan menghasilkan nilai ekonomi yang berdampak pada peningkatan ekonomi masyarakat, terlebih pasca pandemi banyaknya masyarakat yang kehilangan pekerjaan yang disebabkan banyaknya pengurangan pegawai yang diakibatkan terputusnya produksi perusahaan yang mengalami gulung tikar akibat terpuruknya sektor ekonomi dampak pandemi covid-19. Untuk itu memberikan pelatihan menciptakan suatu produk dari potensi daerah menjadi upaya yang produktif didalam memulihkan perekonomian masyarakat.

Kesiapan dalam menghadapi problematika ekonomi kini menjadi hal yang perlu ditangani secara preventif dengan memberikan pembekalan maupun pelatihan yang ada sebagai bekal kompetensi sumber daya manusia yang unggul yang dapat menghasilkan karya dan bernilai ekonomi menjadi upaya dalam menghadapi persoalan yang kini dihadapi masyarakat luas bahkan dunia khususnya pada pemulihan sektor ekonomi dampak wabah covid-19. 


\title{
TETAP BERPRESTASI WALAU PANDEMI TINGGI
}

\author{
Dr. Iim Ibrohim, M.Ag. 8 \\ (FAI UM Bandung, dan Yayasan Mutiara Embun Pagi)
}

\begin{abstract}
"Ada atau tidak adanya masalah, tinggi ataupun rendahnya berbagai tantangan, tidak akan membuat para pencari ilmu lemah. Sebaliknya, setiap permasalahan dan tantangan, dapat dijadikan pendorong untuk tetap berprestasi“
\end{abstract}

$\mathrm{V}$ irus corona masih merajalela. Berbagai upaya strategis sudah banyak dilakukan. Kehadirannya melumpuhkan berbagai sektor kehidupan. Tidak terkecuali dengan sektor pendidikan. Para penyelenggara mulai tingkat Anak Usia Dini hingga Perguruan Tinggi, masih menimbang untuk melangsungkan belajar tatap muka. Hal tersebut sangat dimaklumi, karena risiko yang akan terjadi bukan sekadar basa basi melainkan kematian. Terlebih pemerintah sebagai pemegang otoritas kebijakan belum mengeluarkan ketegasan yang menentramkan.

Tidak dipungkiri, di beberapa daerah yang masuk kategori zona hijau, atau lembaga-lembaga yang sudah merasa jenuh dengan keadaan, mendapatkan banyak tuntutan, serta siap menerapkan prokes super ketat, mulai melakukan simulasi pembelajaran tatap muka terbatas. Sebagian lagi melakukan tatap muka secara penuh walau dilakukan secara sembunyisembunyi. Namun semua itu baru sebagian kecil saja.

${ }^{8}$ Penulis lahir di Tasikmalaya, 01 Mei 1979. Ialah Dosen FAI pada Universitas Muhammadiyah Bandung dan Ketua Yayasan Mutiara Embun Pagi. SI jurusan Pendidikan Agama Islam STAI Siliwangi Bandung (2002), S2 Konsentrasi Pendidikan Agama Islam UIN Sunan Gunung Djati Bandung (2011), dan S3 Pendidikan Islam UIN Sunan Gunung Djati Bandung (2021). 
Selebihnya dituntut bersabar, dan harus masih menjalani Pembelajaran Jarak Jauh (PJJ).

Belum dilakukannya pembelajaran tatap muka, bukan berarti pula kegiatan pembelajaran boleh mati suri. Sama sekali tak ada kegiatan yang berarti. Andai itu terjadi, dapat dikategorikan sebagai sebuah kekonyolan. Seyogianya pada kondisi krisis seperti sekarang ini, berbagai kalangan terdidik tertantang untuk berjuang dan menujukkan kreativitasnya tanpa berbenturan dengan peraturan. Orangorang kreatif dapat memanfaatkan setiap tantangan menjadi peluang. Istilah gaulnya, challenges become opportunities. Keyakinan tersebut, sudah lebih jauh dikhabarkan Allah SWT. dalam firman-Nya; "karena sesungguhnya sesudah ada kesulitan itu ada kemudahan. Sesungguhnya sesudah kesulitan itu ada kemudahan (Al Syarh;5-6).

Perlu disadari, kesulitan dalam belajar seperti sekarang ini bukanlah kali pertama. Para ilmuan terdahulu menghadapi tantangan masing-masing. Untuk mendapatkan ilmu, kadang mereka harus melakukan perjalanan jauh, berdiam diri di tempat sepi, mengulang percobaan, menterjemahkan berbagai referensi, membaca banyak manuskrip, menganalis peristiwa, dan berbagai aktivitas lainnya. Semua dilalui tanpa berpikir bahwa yang dilakukannya cukup melelahkan. Jelasnya, tak ada pemburuan ilmu pengetahuan tanpa dihadapkan permasalahan. Bahkan, semakin tinggi tantangan yang dihadapi, boleh jadi hasil yang akan diraihnya semakin berarti. Kini apa yang terjadi, hasil karya mereka menjadi bacaan fenomenal atau menjadi pijakan keilmuan yang tak pernah usang ditelan zaman. Keadaan tersebut persis pula dengan isyarat Allah SWT. "Dan sesungguhnya yang kemudian itu lebih baik bagimu daripada yang sekarang" (Al Dhuha;4).

Untuk mengatasi permasalahan, setiap unsur pendidikan harus terlibat sesuai kapasitasnya masing-masing. Mereka dituntut untuk berpikir kritis, dan menerapkannya dalam bentuk aksi nyata. Bukan lagi saling menyalahkan terlebih 
merendahkan karena miskin kontribusi. Wabah virus corona ialah masalah bersama. Abad 21 menuntut semua pihak untuk berpikir kritis dan tidak asal-asalan. Berlaku kreatif dalam menghadapi setiap keadaan. Menjalin komunikasi yang penuh arti, dan berkolaborasi dengan berbagai pihak yang memiliki visi. Allah SWT. sudah mewanti-wanti kepada ummat manusia untuk bersatu padu dalam menghadapi berbagai ujian; "Sesungguhnya Allah menyukai orang-orang yang berjuang di jalannya dalam barisan yang teratur seakanakan mereka seperti suatu bangunan yang tersusun kokoh (Al Shaf; 4).

Daripada meratapi, lebih baik mencari solusi. Toh setiap peristiwa yang menimpa, dipastikan membawa hikmah tersendiri. Upaya ini bukan berarti pula menyerah layaknya paham Jabariyah. Namun kita tetap berpikir seraya berzikir, hingga permasalahan ini segera tersingkir. Jangan sekali-kali merasa bahwa yang dirugikan ialah diri kita sendiri. Sebagai contoh, pihak orangtua beranggapan bahwa para guru seolah makan gaji buta tanpa melakukan bimbingan nyata. Setiap harinya hanya meberikan tugas dan tugas saja kepada para siswa. Lalu pihak sekolah beranggapan bahwa orangtua tidak mau bekerja sama. Manakala guru/dosen memberikan tugas, para siswa/mahasiswa sering lambat dalam mengumpulkan. Atau masyarakat menilai bahwa pemerintah kurang serius memikirkan nasib masa depan anak bangsa. Semua itu tidak benar. Baik orangtua, para siswa, pendidik, dan juga pemerintah sama-sama direpotkan. Orangtua yang sibuk bekerja dan tidak terbiasa membimbing belajar tentu akan kewalahan. Para siswa yang tak terbiasa belajar mandiri, apalagi yang tinggal di pesisian dipastikan akan kesulitan. Para guru/dosen terpaksa kerja ekstra. Mengajar bukan lagi pada jam KBM melainkan bisa terjadi 24 jam karena tugas dari siswa/mahasiswa kadang masuk di tengah malam. Demikian juga pemerintah, mereka dipaksa untuk terus memutar otak agar dapat menerbitkan kebijakan yang lebih sedikit madharatnya karena itu suatu keharusan. 
Dalam memposisikan diri agar tetap berprestasi, terdapat beberapa prinsip dasar yang perlu diperhatikan. Jika itu dilakukan, masalah yang dihadapi akan terasa ringan. Prinsip-prinsip tersebut pertama menguatkan sikap ihsan. Manakala sikap ihsan sudah melakat pada setiap jiwa, baik kepada pemangku kebijakan ataupun pelaksana harian, maka ia akan melaksanakan perannya masing-masing dengan penuh kesungguhan. Pun ia akan malu manakala tidak berperan karena Allah SWT. mengawasi dan akan meminta pertanggungjawaban. Dengan tumbuhnya sikap ihsan pula, sudah dipastikan tidak akan muncul sikap berburuk sangka. Masing-masing akan fokus pada perannya masing-masing. Kapan, dimana, dan dalam keadaan apapun selalu beriktikad untuk memberikan yang terbaik.

Prinsip kedua ialah memiliki niatan tulus untuk tetap berjuang. Dengan hadirnya niat tulus, kondisi seperti apapun yang dihadapi takkan pernah menyurutkannya untuk terus menggali. Jika niatan sduah tulus, manakala di akhir pencariannya mendapat hasil sesuai dengan yang diinginkan, tentu itu merupakan buah atas perjuangannya. Namun manakala tidak, ia sudah terlebih dahulu yakin bahwa Allah SWT. tidak menilai seseorang atas hasil melainkan proses yang dijalani dengan penuh kesungguhan.

Prinsip ketiga ialah berani bertindak selama itu dianggap sebagai kebaikan. Dalam keadaan serba kesulitan, ada kalanya kita harus menunggu intruksi, namun ada kalanya pula harus segera berinisi. Para pendidik yang pada masa normal selalu berinteraksi dengan siswanya di dalam kelas, kini tiba-tiba dituntut mampu melakukan pembelajaran jarak jauh. Itu tidak mudah, apalagi menimpa para pendidik yang tidak melek teknologi. Orangtua yang tak terbiasa membimbing anaknya di rumah, mesti berani melakukan pendampingan. Semua membutuhkan proses, hingga akhirnya menjadi sebuah pembiasaan. At the firt we make habit. At the last habit make us. 
Keempat ialah hadirnya semangat perubahan/pergerakan. Para ulama mengatakan, "taharrak, taharrak, liana fil harakati barakatun". Bergeraklah, bergeraklah, karena sesungguhnya dalam pergerakan itu penuh dengan keberkahan. Semua unsur pendidikan dari mulai pemerintah hingga siswa, tidak boleh merasa puas dengan cara yang selama ini dilakukan. Para guru yang sudah mulai terbiasa menggunakan salah satu teknik pembelajaran online, orangtua yang kembali mencoba melakukan pendampingan, dan juga para siswa saat melakukan pembelajaran, dituntut untuk melakukan pembaharuan. Jangan sampai terlena dengan cara yang sama, karena itu bisa menghadirkan kejenuhan.

Untuk semangat perubahan, pemerintah sebagai pemegang otoritas, dapat memilih strategi tepat dan menerapkannya bagi para penyelenggara pendidikan sehingga perubahan itu benar-benar terjadi. Setidaknya terdapat empat strategi yang dapat dipilih. Keempat strategi tersebut; 1) strategi faslitatif, yang tepat diterapkan pada sekolah-sekolah unggulan yang terbiasa menghasilkan perubahan. 2) strategi pendidikan, yaitu bagi sekolah-sekolah memiliki semangat perubahan namun merasa kesulitan. 3) strategi bujukan, yang tepat diperuntukkan bagi sekolah yang lemah kreativitas, kurang memiliki keinginan, hanya menunggu intruksi atasan. Meraka harus dibujuk agar bangkit dan mau berkreasi, dan ke-4) strategi paksaan yang diterapkan bagi sekolah-sekolah yang sama sekali tidak ada kreativitas, tidak memiliki keinginan, malas berprestasi untuk mencapai tujuan perubahan.

Prinsip kelima ialah semangat untuk menularkan kreativitas. Bagi yang terbiasa melakukan perubahan, menemukan dan menerapkan hal-hal baru ialah sesuatu yang mudah. Namun bagi sebagian kalangan, itu akan dirasa berat. Oleh karena itu, temuan-temuan dari setiap perubahan, sebaiknya disebarluaskan untuk kemudian dapat diadaptasi oleh yang lainnya. Adaptor, dapat meniru melalui Teknik 
mudah seperti ATM (Amati, Tiru dan Modifikasi), atau SCAMPER yaitu Substitute (pergantian), Combine (penggabungan), Adopt (adopsi/adaptasi), Modify (menambah atau mengurangi), Put to other uses (menggunakan dalam bentuk lain), Eliminate (menghapus/membuang), dan Reverse (membalik/mengatur ulang).

Selain lima perinsip tersebut di atas, untuk tetap berprestasi walau pandemi tinggi, terdapat beberapa faktor yang perlu diperhatikan. Faktor-faktor tersebut di antaranya peran dari para pelaku pendidikan seperti ketua yayasan, kepala sekolah, pendidik dan tenaga kepandidikan. Mereka semua dituntut bekerja keras. Jangan hanya menunggu intruksi pemerintah, melainkan terus berpikir agar pembelajaran dapat berlangsung dan kualitas pendidikan tidak menurun. Visi, misi, dan tujuan pendidikan yang sudah dibuat harus tercapai.

Bagi sekolah yang kreatif, situasi belajar seperti sekarang ini dapat dijadikan media untuk meningkatkan pencapaian. Pendidik dapat memfasilitasi para siswa untuk bersaing secara global. Bukan hanya berkompetisi teman satu sekolahnya, melainkan dengan sekolah lain bahkan wilayah, dan negara lain. Orangtua dapat lebih leluasa dalam mengembangkan karakter dan kecerdasan putra putrinya, serta para siswa dapat lebih tergali dan terkembangkan kecerdasannya karena orangtua yang mendampingi, sudah dipastikan lebih mengenal karakter dan berbagai potensi kecerdasan yang dimilikinya.

Howard Gardner misalnya mengatakan, terdapat delapan kecerdasan anak yang dapat dikembangkan orangtua dan guru. Kedelapan kecerdasan tersebut yaitu; linguistik (word smart), logika (number smart), interpersonal (self smart), interpersonal (people smart), musikal (music smart), spasial (Picture smart), kinetik (body smart), dan naturalis (nature smart). Jika prinsip-prinsip dasar serta faktor-faktor pendukungnya diperhatikan, sudah barang tentu prestasi 
dari setiap siswa akan selalu muncul dan tetap terjaga. Ada atau tidak adanya masalah, tinggi ataupun rendahnya berbagai tantangan, tidak akan membuat para pencari ilmu lemah. Sebaliknya, setiap permasalahan dan tantangan, dapat dijadikan pendorong untuk tetap berprestasi. 


\title{
PANDEMI (BUKAN) SOLUSI PENDIDIKAN ERA REVOLUSI INDUSTRI 4.0
}

\author{
Mawardi, M.Pd. ${ }^{9}$ \\ (Dayah Terpadu Almuslimun Aceh Utara)
}

"Teruslah ambil posisi yang menguntungkan dalam segala sudut tekanan kebutuhan sesuai perkembangan zaman. Semoga coronavirus segera berakhir dan kehidupan era revolusi industry 4.0 terus berlanjut hingga tahap 5.0 dan seterusnya."

$\mathrm{T}$ arget pendidikan Indonesia hari ini sejalan dengan model penerapan revolusi industry 4.0, segala aktifitas serba didigitalisasikan (Syamsuar \& Reflianto, 2019). Komunikasi antara tenaga pendidik dan peserta didik dapat dilakukan dengan mudah via digital seperti aplikasi zoom, google meets, webinar, dan lain-lain. Aktifitas ini dapat berjalan dengan baik tanpa batasan jarak tertentu antar pengguna, (larangan tatap muka secara langsung sebab pandemic bukan suatu hambatan dalam kondisi digitalisasi). Selain itu, sumber belajar tidak hanya dapat diperoleh dari buku panduan belajar saja, akan tetapi sumber belajar dapat di diperoleh dengan mudah via digital dasar seperti smartphone, internet dan sejenisnya (Setiyani, 2010).

${ }_{9}$ Penulis lahir di Aceh Utara, 25 Juli 1986. Penulis merupakan seorang guru pendidikan bahasa Inggris pada Madrasah Tsanawiyah Swasta Dayah Terpadu Almuslimun Lhoksukon Aceh utara. Penulis menyelesaikan gelar sarjana pendidikan bahasa Inggris di Universitas Samudra Langsa tahun 2012 dan menyelesaikan gelar megister pendidikan bahasa Inggris di Universitas Syiah Kuala Banda Aceh pada tahun 2021. 


\section{Kondisi Indonesia (Maret 2020 sampai dengan sekarang)}

Kasus Coronavirus19 (Covid-19) di Indonesia meningkat setiap harinya. Virus Covid-19 menjadi salah satu pusat perhatian bagi bangsa Indonesia dalam 1 tahun tearakhir. Pandemi wabah ini berdampak luas terhadap masyarakat terutama pada perekonomian, kesehatan, pendidikan dan lainya (Siahaan, 2020., Kennedy, 2020., Tapung et el 2020) . Dimulai pada pertengahan tahun 2020, banyak asumsi mneyatakan bahwa pandemi ini akan berdampak negative secara global. Asumsi tersebut semakin kuat saat pemerintah menetapkan aturan larangan beraktifitas diluar rumah bagi masyarakat Indonesia secara umumnya, aturan tersebut dinamai dengan istilah Pembatasan sosial berskala besar (PSBB).

Pembatasan aktifitas tertentu masyarakat di suatu wilayah terinfeksi wabah atau terkontaminasi suatu wabah dilakukan oleh pemerintah guna mencegah kemungkinan penyebaran yang lebih luas. PSBB merupakan salah satu jenis penyelenggaraan kekarantinaan kesehatan pada suatu daerah tertentu (Hasrul, 2020). Adapun tujuan PSBB yaitu mencegah meluasnya penyebaran virus yang sedang terjadi antar orang di suatu wilayah tertentu. Pembatasan aktifitas yang dilakukan meliputi peliburan sekolah, penutupan tempat kerja, pembatasan kegiatan keagamaan, serta pembatasan rutinitas pada tempat-tempat umum.

Secara garis besar, pembatasan ini adalah suatu karantina dan tekanan oleh suatu negara terhadap masyarakatnya pada tempat-tempat khalayak ramai. Namun demikian, pembatasan malah memberi dampak yang baik untuk implementasi era industry 4.0. Pandemi hari ini mampu mengubah pola kehidupan sosial sehari-hari. Transisi era digitaslisasi dari analog terjadi dengan cepat disebabkan tekanan pandemi Covid-19.

Adapun pendidikan di Indonesia umumnya dilaksanakan secara tatap muka (Kuntarto, 2017). Tetapi hari ini, 
mayoritas lembaga pendidikan negeri dan institusi swasta mulai melakukan pertemuan secara online, baik di sekolah, di perguruan tinggi, meeting kerja guru, hingga seminar ilmiah dilaksanakan secara online. Pandemic hadir seolah solusi untuk revolusi Industri 4.0.

Pemerintah mengharapkan guru menjadi fasilitator dan pemandu pembelajaran. Selain itu, pemerintah mengharapkan siswa berkarakter mandiri dengan nengedepankan active learning, hal ini tertuang dalam beberapa mnetode dan teknik pembelajaran resmi di Indonesia. Artinya, guru sebagai fasilitator hanya memberi petunjuk gambaran umum teori dan praktikum yang akan dibahas, selanjutnya siswa dituntut aktif dalam memperdalam ilmu yang sedang dibahas. Peserta didik dapat memperdalam suatu teori secara mandiri dengan mencari berbagai sumber teori dan juga dapat dilakukan secara kelompok atas dasar petunjuk pelaksanaan yang ditentukan oleh tenaga pengajar. Selain itu, peserta didik juga dapat mengerjakan latihan soal dan ujian secara jarak jauh tanpa harus tatap muka langsung dalam suatu tempat pertemuan khusus (Seperti ruang belajar, aula, lab computer, dll).

Pandemic ini juga berdampak positif pada keuangan. Biaya pendidikan hari semakin hemat dibandingkan sebelum pademi. Umumnya konferensi internasional sebelumnya dilakukan secara langsung, anggaran transportasi diperlukan untuk pertemuan tersebut, namun hari ini, kegiatan internasional dapat dilakukan di ruang pribadi masingmasing. Kondisi hari ini mempermudah praktisi pendidikan menjalankan segala seuatu dari manual menuju digitalisasi dari jarak tanpa batas. Dr Achmad Istamar, CEO Esri Indonesia mengatakan bahwa pandemic COVID-19 saat ini dianggap berhasil mempercepat transformasi digital di berbagai industri. Hal ini dikarenakan para pelaku industri yang dituntut untuk menemukan cara tetap menjalankan rutinitas tertentu di era new normal. 
Revolusi Industri 4.0 dicetuskan pertama kali pada tahun 2011 di Hannover Trade Fair oleh sekumpulan perwakilan ahli berbagai bidang dari negeri Jerman. Pada event tersebut disampaikan bahwa industri saat ini telah memasuki inovasi baru. Pemerintah Jerman meresmiklan gagasan tersebut seraya membentuk kelompok khusus guna pembahasan mengenai penerapan rovolusi tersebut.

Empat tahun setelahnya, Angella Markel memperkenalkan Revolusi Industri 4.0 di acara World Economic Forum (WEF). Jerman mengeluarkan modal besar untuk praktisi akademisi, pemerintah, dan pebisnis untuk melakukan penelitian lintas akademis mengenai Revolusi Industri 4.0 tersebut. Negara yang dijuluki super power juga ikut andil pada waktu tersebut..

Secara keseluruhan revolusi industri 4.0 sudah dimulai sejak 2011. Dimulai dari jerman hingga beberapa Negara maju lainnya yang menganggap revolusi iniharus berjalan sesuai kebutuhan zaman. Di sisi lain, beberapa negara berkembang belum mampu mulai langkah tersebut pada waktu bersamaan sebab kendala keterbatasan Sumber Daya Manusia (SDM) dan hal lainya.

Hari ini, coronavirus menjajaki seluruh belahan dunia seolah menjadi komando utama penggerak digitalisasi segala rutinitas penduduk bumi. Wabah yang sebelumnya dianggap parasit induk dampak kemunduran suatu Negara malah menjadi kumpang penyebar bibit unggulan.

Tidak dipungkiri, dampak negative dari covid-19 adalah nyata adanya, namun dampak positif karena pandemic ini juga bukan angka yang kecil patut untuk dijadikan hikmah. Teruslah ambil posisi yang menguntungkan dalam segala sudut tekanan kebutuhan sesuai perkembangan zaman. Semoga coronavirus segera berakhir dan kehidupan era revolusi industry 4.0 terus berlanjut hingga tahap 5.0 dan seterusnya. 


\section{Daftar Pustaka}

Hasrul, M. (2020). Aspek Hukum Pemberlakuan Pembatasan Sosial Berskala Besar (PSBB) Dalam Rangka Penanganan Corona Virus Disease 2019 (Covid19). Jurnal Legislatif, 385-398.

Kennedy, P. S. J. (2020). Dampak COVID-19 terhadap Perekonomian.

Kuntarto, E. (2017). Keefektifan model pembelajaran daring dalam perkuliahan bahasa Indonesia di perguruan tinggi. Indonesian Language Education and Literature, 3(1), 99-110.

Setiyani, R. (2010). Pemanfaatan internet sebagai sumber belajar. Dinamika Pendidikan, 5(2).

Siahaan, M. (2020). Dampak pandemi Covid-19 terhadap dunia pendidikan. Dampak Pandemi Covid-19 Terhadap Dunia Pendidikan, 20(2).

Syamsuar, S., \& Reflianto, R. (2019). Pendidikan dan tantangan pembelajaran berbasis teknologi informasi di era revolusi industri 4.0.E-Tech: Jurnal Ilmiah Teknologi Pendidikan, 6(2).

Tapung, M. M., Regus, M., Payong, M. R., Rahmat, S. T., \& Jelahu, F. M. (2020). Bantuan sosial dan pendidikan kesehatan bagi masyarakat pesisir yang terdampak sosial-ekonomi selama patogenesis Covid-19 di Manggarai. Transformasi: Jurnal Pengabdian Masyarakat, 16(1), 12-26. 


\title{
PEMANFAATAN WAKTU LUANG MAHASISWA DALAM PENINGKATAN DIRI DI TENGAH PANDEMI COVID-19
}

\author{
Dra. Widiastuti, MM. ${ }^{10}$ \\ (Universitas Darma Persada)
}

\begin{abstract}
"Mahasiswa berupaya menyesuaikan diri dalam kondisi pembatasan sosial yang menjadi kebijakan pemerintah dengan menggunakan waktu luangnya untuk meningkatkan kemampuan diri mahasiswa dengan berbagai aktivitas yang sesuai dengan minat, bakat, hobi dan pengetahuan yang dimiliki"
\end{abstract}

Badan dunia WHO (World Health Organization) pada pandemi karena covid-19 sebagai salah satu penyakit menular yang berbahaya. Seperti negara lain, Indonesia berupaya mengantisipasi melalui kebijakan Permenkes No. 9 tahun 2020 tentang pedoman pembatasan sosial berskala besar dalam rangka percepatan penanganan corona virus disease 2019 (covid-19) atau PSBB. Dalam penerapan PSBB dilakukan pembatasan semua kegiatan perkantoran, dan industri yang sifatnya non esensial termasuk didalamnya institusi Pendidikan. Kenyataannya sampai saat ini pandemi covid-19 mengalami kondisi pasang surut penyebarannya di masyarakat, hal ini menyebabkan kebijakan pembatasan sosial yang terus berlanjut.

10 Penulis merupakan Dosen Universitas Darma Persada dalam bidang Ilmu Manajemen, penulis menyelesaikan gelar Sarjana Pendidikan di IKIP Jakarta (1988) sekarang Universitas Negeri Jakarta dan gelar Magister Manajemen diselesaikan di Universitas Krinadwipayana Jakarta (2004). 
Perubahan aktivitas kehidupan dimasyarakat mulanya bebas menjadi terbatas, dampak dari keterbatasan tersebut menimbulkan masalah baru. Kaustav \& Moumita (dalam Rully:2021) melaporkan hasil penelitiannya bahwa perasaan khawatir dialami mayoritas individu akibat masalah finansial, selain itu dampak lain munculnya gejala depresi dan sulit menyesuaikan diri dari kondisi dimasa pandemi covid-19. Menghadapi kondisi dan dampak yang tidak diinginkan tersebut, khususnya di bidang Pendidikan Tinggi, keluar kebijakan pembelajaran daring melalui instruksi kepada seluruh Perguruan Tinggi di Indonesia untuk melaksanakan pembelajaran secara daring dan bekerja dari rumah guna pencegahan penyebaran covid-19, melalui surat edaran Kementerian Pendidikan dan kebudayaan No. 302/E.E2/KR/2020 tertanggal 31 Maret 2020.

Berbagai sosialisasi adaptasi kebiasaan baru diperkenalkan kemdikbud menghadapi perkuliahan daring melalui seminar, pelatihan webinar dengan sasaran sivitas akademik seperti tenaga pendidik, tenaga kependidikan dan mahasiswa.

Selain itu bantuan diberikan kepada dosen dan mahasiswa berupa kuota internet serta keringanan biaya kuliah mahasiswa yang orang tua mahasiswa terdampak pandemi covid-19. Proses yang terjadi pada pembelajaran daring memaksa mahasiswa meningkatkan kemampuan diri terhadap kegiatan daring yang belum pernah dialami sebelumnya, mulai dari penguasaan komputer, jaringan internet hingga aplikasi pendukung yang jika tidak dikuasai dengan baik dapat mengganggu kelancaran belajar mengajar.

Masalah keterbatasan ruang dan aktivitas, yang waktunya banyak dilalui dirumah dirasakan mahasiswa, sebelum pandemi kegiatan sehari-hari bisa di rumah, di kampus, di ruang terbuka dan tempat umum. Dampak pikologis yang terjadi muncul rasa bosan, kecewa, cemas bahkan depresi. Penelitian Raldy A dkk (2021) diketahui muncul kecemasan, depresi, stress yang dialami oleh mahasiswa, terutama 
mahasiswa tahun pertama kuliah dengan gejala psikologis yang lebih tinggi dibanding mahasiswa yang lebih senior, mahasiswa perempuan lebih mendominasi gejala psikologis ini dibanding mahasiswa laki-laki. Dapat dipahami mahasiswa yang kuliah di tahun pertama dimasa pandemi merasakan peralihan dari Pendidikan Menengah Atas yang berbeda atmosfir pembelajaran dengan perguruan tinggi yang minim adaptasi, memaksa dirinya untuk belajar mandiri.

Aktivitas yang terbatas timbul banyak waktu luang, kebiasaan bercengkrama dengan teman, kerabat menjadi terbatas saat ini. Pada awalnya membingungkan mahasiswa bagaimana menemukan aktivitas kegiatan pengisi waktunya dengan tepat. Terlalu lama memakai fasilitas online juga menimbulkan kejenuhan, belum lagi masalah jaringan internet lemah, dana untuk membeli paket internet terbatas, membuat mahasiswa mengalami kekecewaan bahkan depresi. Upaya mengatasi hal tersebut muncul dari dalam diri mahasiswa maupun dari luar seperti dukungan keluarga, teman maupun dari media.

Menurut Rohmat (dalam Putri, 2020) waktu luang sebagai kesediaan waktu diluar kegiatan yang dilakukan sehari-hari, pemahaman waktu luang sering ditafsirkan sebagai tidak ada kegiatan lalu dipakai untuk bersantai dan bermalas-malasan. Justru adanya waktu luang dimanfaatkan untuk kegiatan yang berdampak positif melalui hobi atau kegiatan yang diminati, menambah pengetahuan, kegiatan mendapatkan penghasilan dan kegiatan sosial

Dorongan dapat bersumber dari faktor internal dan eksternal, faktor internal Ketika seseorang melakukan kegiatan atas kemauan sendiri dengan mempertimbangkan kekuatan atau kemampuan yang ada pada dirinya karena kebutuhan atau keinginan. Dorongan akibat faktor eksternal muncul karena pengaruh dari luar bisa berupa trend, pengaruh teman, keluarga atau kondisi dan situasi yang ada pada saat itu (Moekijat, 2005). 
Upaya mengetahui mahasiswa dalam memanfaatkan waktu luang untuk meningkatkan diri, dilakukan melalui observasi kepada mahasiswa program studi Bahasa Inggris D3 semester 5 (lima) Fakultas Sastra Universitas Darma Persada di semester ganjil tahun akademik 2020/2021. Dengan responden berjumlah 18 mahasiswa, observsi dilakukan melalui pembuatan tugas daily activity yaitu laporan kegiatan yang dilakukan dirumah dan lingkungan mahasiswa dalam rangka pemanfaatan waktu luang mereka selain kegiatan kuliah daring, laporan dibuat dalam bentuk video dan presentasi dalam bahasa Inggris.

Hasil observasi melalui tugas daily activity yang dilakukan mahasiswa, dapat dijelaskan berikut ini. Seluruh responden menyukai hiburan dalam bentuk menonton film, youtube, mendengarkan musik dan bermain game sebagai pengisi waktunya. Kegiatan ini dilakukan setelah penat menyelesaikan tugas, kuliah daring dan pekerjaan rutin dirumah. Kegiatan rutin yang dilakukan dirumah selain belajar dan kuliah berupa kegiatan membantu pekerjaan sehari-hari seperti menyapu, mengepel lantai, mencuci piring, mengosok baju, membersihkan motor, kegiatan ini secara rutin dilakukan oleh 6 responden sedangkan responden lainnya tidak rutin membantu pekerjaan dirumah.

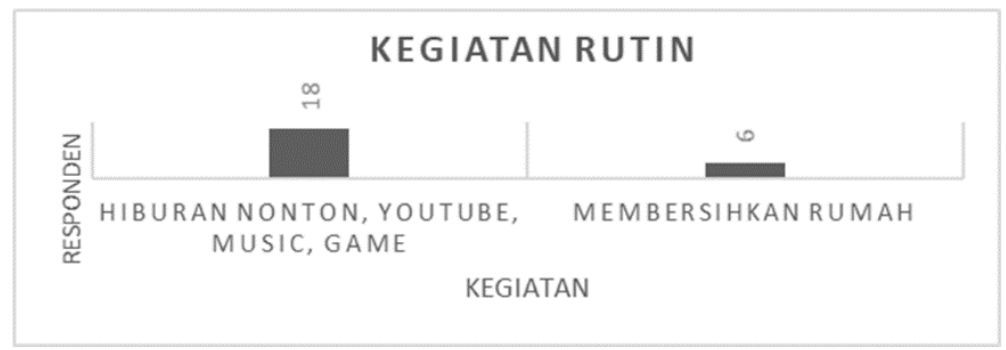

Gambar 1. Grafik Kegiatan Rutin

Aktivitas pengembangan diri berupa kegemaran/hobi, menambah pengetahuan dan keahlian yaitu 1) 1 responden mengikuti organisasi karang taruna, 2) berlatih musik 
dengan gitar, drum dan akustik diminati oleh 3 responden, 3) membaca buku menjadi kegermaran 4 responden, 4) hobi melukis dilakukan oleh 1 responden, 5) menulis kisah/karangan 1 responden, 6) mempelajari Bahasa asing selain Bahasa Inggris yaitu Bahasa Mandarin ditekuni 2 responden, 7) belajar kuliner dipilih oleh 7 responden perempuan dengan minat pada masakan nusantara, jepang, korea, dan kuliner dari negara barat. 8) kegiatan berkebun juga menjadi perhatian dalam masa pandemi covid-19 dijadikan hobi baru oleh 3 responden dan 9) memelihara hewan peliharaan seperti kucing, kelinci dan tikus belanda (guine pig) diminati 3 responden.

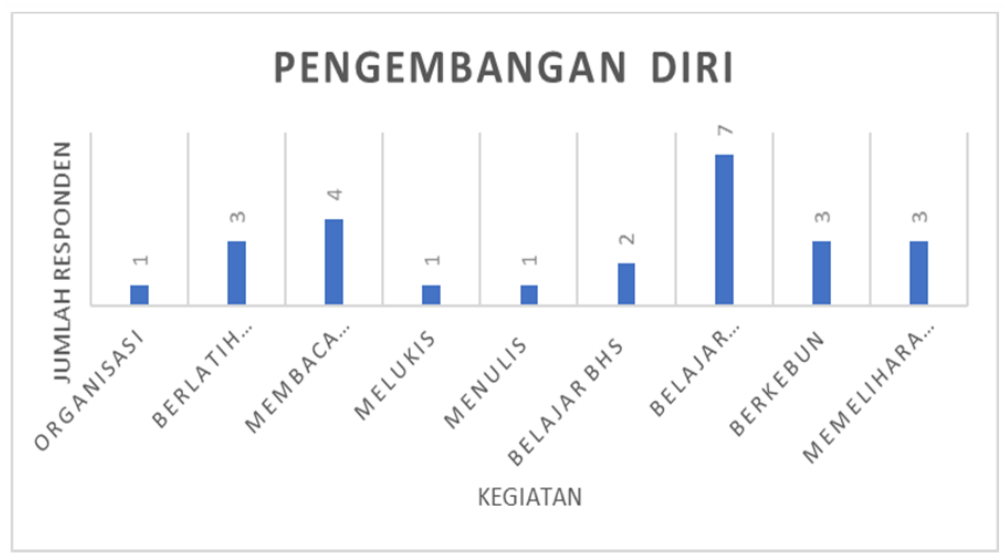

Gambar 2. Grafik Kegiatan Pengembangan Diri

Kegiatan berkaitan dengan kesehatan dan kebugaran 1) olah raga dilakukan oleh responden dirumah dan di lingkungan sekitar yaitu yoga, zumba, holahop, aerobik, badminton dan bersepeda, secara rutin dilaksanakan oleh 6 responden, 2) kesempatan waktu luang juga dimanfaatkan untuk melakukan perawatan diri agar tetap sehat dan cantik secara rutin dilakukan oleh 2 responden, 


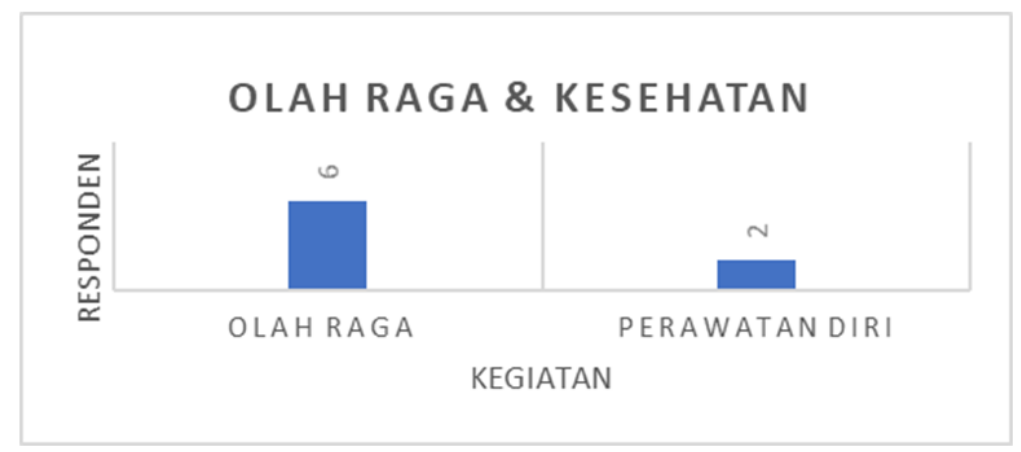

Gambar 3. Kegiatan Olah Raga dan Kesehatan

Kegiatan peningkatan diri dalam bidang usaha dengan mengembangkan bakat dan pengetahuan yang dimiliki sebagai pemenuhan aspek ekonomi berupa 1) bekerja paruh waktu (part time) dilakukan oleh 4 responden dengan memanfaatkan hobi dibidang musik dalam live musik di beberapa coffee shops, mengajar privat Bahasa Indonesia dan Bahasa Inggris untuk anak-anak, 2) wirausaha guna menambah penghasilan lewat usaha makanan dan penjualan barang bekas yang di lakukan oleh 2 responden.

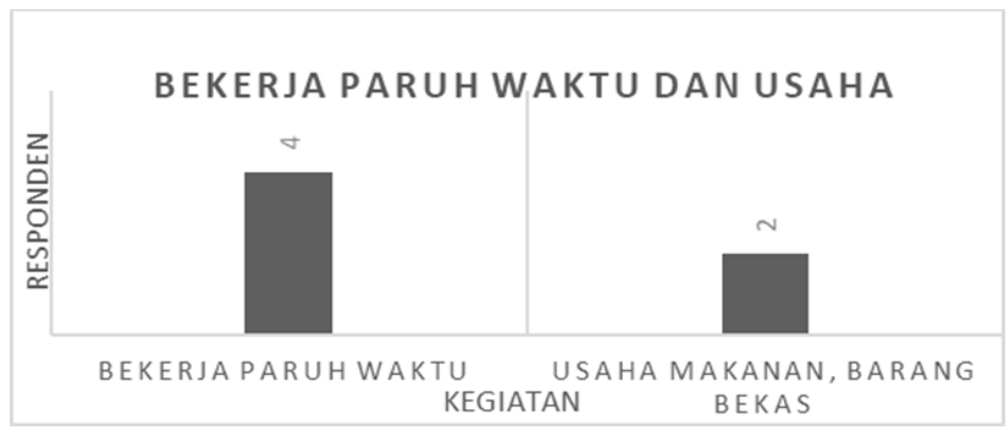

Gambar 4. Kegiatan Paruh Waktu dan Usaha

Dari uraian diatas dapat dikatakan bahwa mahasiswa Bahasa Inggris semester 5 tahun akademik 2020/2021 
Fakultas Sastra Universitas Darma Persada berupaya menyesuaikan diri dalam kondisi pembatasan sosial yang menjadi kebijakan pemerintah dengan menggunakan waktu luangnya untuk meningkatkan kemampuan diri mahasiswa dengan berbagai aktivitas yang sesuai dengan minat, bakat, hobi dan pengetahuan yang dimiliki.

\section{Daftar Pustaka}

Afrita Harlianty, Rully,, Nurzanah, Eka, Sunarmi., Nurhayati, Mukhlis, Hamid., 2021. Manajemen Krisis Dimasa Pandemi. Indonesia Berdaya, 2(1):7-12: Januari 2021 P-ISSN:2716-3822, E-ISSN:2721-0669

A, Raldy., Ratunuman, E, Lydia., David,V., Opod,Hendri., 2021. Dampak Psikologis Pandemi COVID-19 Pada Mahasiswa. Jurnal Biomedik. 2021;13(2):227-232 pISSN2085-9481, eISSN2597-999X

Maharani, Anak Agung Putri., Suparsa, I Nyoman., Maysi, Kadek., 2020. Pemanfaatan Waktu Luang Pada AnakAnak Di Desa Dauh Puri Kauh Dimasa Pandemi Covid19. Prosiding Seminar Regional Pengabdian Kepada Masyarakat Unmas Denpasar di Masa Pandemi Covid19 tahun 2020

Moekijat. 2005. Manajemen Personalia dan Sumber Daya Manusia. Bandung: Mandar Maju 


\section{BAB II}

\section{KEGIATAN SPIRITUAL SAAT PANDEMI}

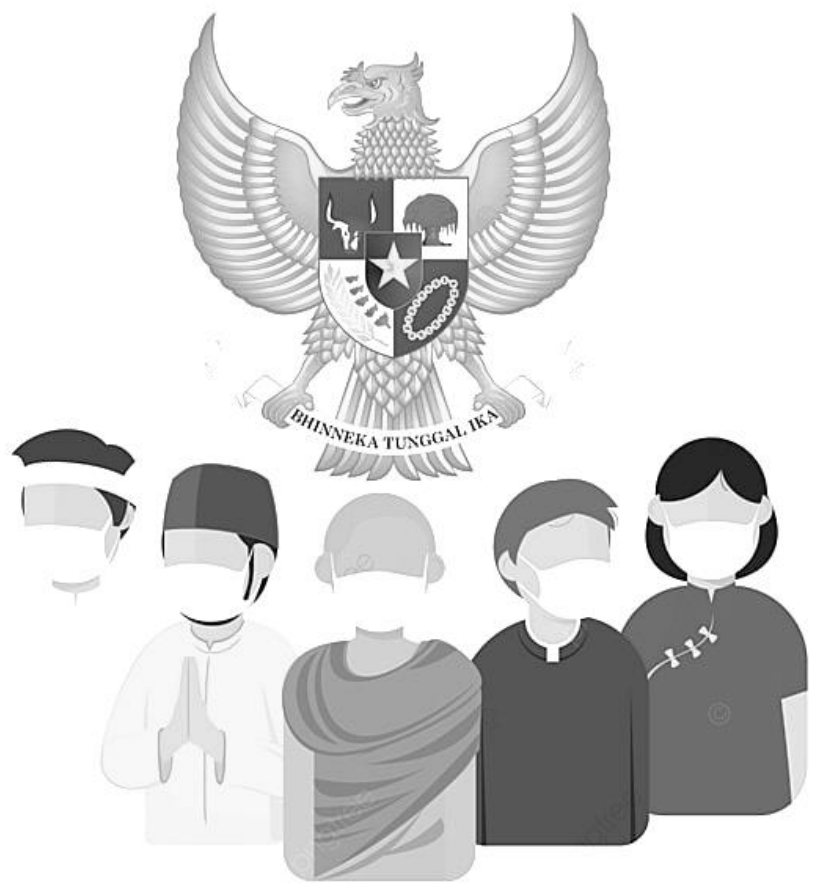




\title{
OPTIMALISASI KOMPETENSI DA'IYYAH DI MASA PANDEMI COVID-19
}

\author{
Siti Marlida,M.Ag ${ }^{11}$ \\ (Universitas Muhammadiyah Bandung)
}

\begin{abstract}
"Da'iyyah harus kreatif dan inovatif dalam dakwah dengan memanfaatkan kemajuan teknologi komunikasi dan media sosial yang semakin luas dan beragam"
\end{abstract}

I Slam mengangkat derajat kaum perempuan dan memuliakan kedudukan nya sesuai dengan fitrah nya sebagai pasangan yang saling melengkapi dengan kaum lelaki. Penghormatan Islam kepada kaum perempuan bukan hanya diberikan hak dan kewajiban dalam urusan domestik di rumah tangga dan mendidik anak-anak nya saja, Namun kaum perempuan diikutsertakan juga dalam ranah public dan sosial termasuk keterlibatan nya dalam aktifitas dakwah. Di awal kehadiran Islam, kontribusi kaum perempuan khusus nya para istri nabi dalam membangun dan menopang aktiftas dakwah nabi Muhammad SAW sungguh luar biasa sangat mengagumkan menjadi catatan tinta emas dalam perjalanan sejarah perkembangan Islam.

Bukti perjuangan dan keberhasilan kaum muslimah dalam dakwah misal nya ada Saudah binti Zam'ah yang mendakwahi keluarga nya sampai suami nya masuk Islam. Ada Fatimah Binti Khattab ditemani suami nya yang

\footnotetext{
${ }^{11}$ Penulis lahir di Bekasi 17 Oktober 1970, penulis adalah dosen di Universitas Muhammadiyah Bandung dalam bidang ilmu Dakwah.Penulis menyelesaikan gelar Sarjana Bahasa Arab di Institut Agama Islam Negeri tahun 1995 sedangkan gelar Sajana Ilmu Dakwah di selesaikan di Universitas Islam Negeri Bandung tahun 2010. Selain mengajar, aktifitas penulis saat ini sebagai pengisi berbagai Majlis Taklim dan mengelola yayasan Pendidikan
} 
mendakwahi kakak nya yaitu Umar Bin Khattab sampai beliau masuk Islam. Ada Siti Khadijah mencurahkan ,seluruh harta nya untuk dakwah hingga nyaris tak bersisa sampai saat Siti Khadijah hendak meninggal, meminta sorban nabi untuk kain kafan nya. Demikian pula peran Siti Aisyah sebagai sosok istri yang cerdas \& faham dengan semua ilmu agama yang diajarkan oleh nabi Muhammad SAW. Beliau menjadi tempat bertanya kaum muslimin khusus nya kaum perempuan. Perjuangan dakwah para istri nabi \& shahabiyat diabadikan dalam Al-Quran dan Al-Hadits agar menjadi pelajaran dan suri tauladan kaum muslimin .

Seiring dengan perjalanan waktu dan meluas nya perkembangan Islam ke seluruh penjuru dunia, peran kaum muslimah sebagai juru dakwah atau da'iyyah yang menyampaikan amar ma'ruf nahyi munkar semakin dibutuhkan. Penting nya peran seorang perempuan dalam dakwah agar dapat mendidik dan membimbing kaum nya dalam melaksanakan ajaran Islam karena banyak sekali ajaran Islam terkait tugas dan kewajiban perempuan baik di lingkup internal rumah tangga amaupun di ranah sosial yang memerlukan penjelasan secara detail dan spesifik,.misal tatacara memandikan jenazah perempuan, tatacara mandi janabah dan lain sebagai nya. Kaum perempuan harus belajar banyak ilmu agama karena tugas nya tidak ringan sebagai pendidik anak-anak nya, sebagai ibu peradaban dan dai'iyyah bagi kaum nya.

Di sisi lain perkembangan masyarakat dan kemajuan tekonologi melahirkan tantangan dakwah dan problema yang sangat berat sehingga dibutuhkan para daiyyah yang berkualitas dan mumpuni yang dapat menyampaikan ajaran Islam lebih mudah dimengerti, serta memotivasi kaum nya agar mengamalkan ajaran Islam secara sungguh-sungguh. Bahkan perempuan sebagai da'iyyah harus mampu menjawab persoalan masyarakat secara benar sesuai kaidah dan aturan Islam.Oleh karena itu para dai'yyah harus dibekali keilmuwan dakwah yang komprehensif dan beragam skill 
yang menunjang kemudahan serta kelancaran dalam berdakwah terutama sekarang ini ketika wabah Covid melanda dunia.

Pandemi covid 19 telah melumpuhkan ruang ruang kehidupan. Semua upaya ditujukan bagaimana menjaga kesehatan jasmani dan menghindari penularan covid 19 secara massiv. Sesungguh nya bukan hanya aspek kesehatan jasmani saja yang perlu ditangani secara serius namun aspek kesehatan mental spiritual manusia juga penting di perhatikan karena Kesehatan mental spiritual manusia menjadi pondasi penting terbentuknya aspek kesehatan jasmani.Sedangkan salah satu tujuan dakwah diantaranya adalah untuk memenuhi kesehatan mental spiritual seorang muslim agar selama hidup nya terhindar dari prilaku buruk yang dapat merusak mentalnya, menyelamatkan manusia dari jurang kejahatan sehingga mampu meraih ketenangan dan kebahagiaan di dunia maupun di akhirat kelak.

Pada masa covid 19 ini, semua aktifitas dibatasi termasuk aktifitas ibadah dan dakwah. Namun dakwah sebagai lentera kehidupan manusia tidak boleh terhenti apalagi dibatasi oleh ruang dan waktu. Dakwah harus tetap mewarnai gerak langkah umat muslim dalam menyebarkan ajaran Islam.Bila dakwah padam maka kehidupan akan diselimuti oleh kerusakan, kemaksiyatan dan manusia terperangkap dalam kedzhaliman serta kesesatan .

Menurut Nawawi jalan dakwah amatlah panjang dan berliku. Rintangan-rintangan yang ringan sampai yang terberat telah menghadang para juru dakwah. Oleh karena itu para da'iyyah harus melakukan persiapan yang matang sebelum mereka terjun ke medan dakwah karena untuk mengubah pola pikir dan perilaku seseorang supaya mengikuti ajaran Islam tidaklah mudah, maka agar dakwah dapat berjalan efektif \& efisien harus mengoptimalkan kompetensi para da'iyyah di masa pandemi covid 19 ini. 
Secara etimologi istilah kompetensi berasal dari bahasa Inggris

"Competency" yang artinya kecakapan atau kemampuan. Menurut Mc Ashan.Kompetensi diartikan sebagai pengetahuan, keterampilan, dan kemampuan yang dikuasai oleh seseorang yang telah menjadi bagian dari dirinya sehingga ia dapat melakukan perilaku-perilaku kognitif, afektif, dan psikomotorik dengan sebaik-baiknya. Pendapat Hasmy kompetensi dai adalah pengetahuan, pemahaman, perilaku,serta ketrampilan tertentu yang harus dimiliki seorang dai agar mereka dapat melakukan tugasnya dengan baik. Dengan demikian, kompetensi bagi seorang dai adalah suatu penggambaran yang ideal, sekaligus sebagai target yang harus mereka penuhi

Menurut Sa'ad Al-Qahthani sebagaimana dikutip oleh Juhari Hasan antara lain, kompetensi seorang da'i harus (1) berilmu, (2) arif dan santun, (3)lemah lembut, (4) sabar, (5) jujur dan ikhlas, dan (6) keteladanan. Abdul Munir Mulkhan, membedakan kompetensi dai menjadi dua, yaitu kompetensi substantif dan kompetensi metodologis. Kompetensi substantif adalah sifat dan kemampuan da'i yang harus ada dalam dirinya sedangkan kompetensi metodologis adalah kemampuan da'i dalam menganalisa kondisi dan mengenali secara detil kondisi obyek dan medan dakwah sebagai bekal landasan seorang da'i dalam menyusun perencanaan dakwah. Hal-hal yang termasuk kriteria kompetensi substanif seorang da'i di antara nya:

1. Pemahaman agama Islam secara cukup, tepat dan benar:

2. Pemahaman hakikat gerakan dakwah

3. Memiliki akhlak al karimah: setiap da'i harus memiliki akhlak yang mulia karena mereka akan dijadikan panutan oleh masyarakat, ia akan selalu diikuti oleh umat.

4. Mengetahui perkembangan ilmu pengetahuan umum yang relatif luas

5. Mengetahui audience dengan tulus 
6. Mengenal kondisi lingkungan dengan baik

7. Memiliki rasa ikhlas liwajhillah

Mengingat kondisi \& medan dakwah di masa pandemi ini telah mengubah proses interaksi sosial dan komunikasi, maka seyogyanya da'iyyah melakukan evaluasi cara kerja dakwah nya.Menurut Ahmad Fauzi Jika pada kondisi normal biasanya kajian-kajian dakwah bisa dilakukan dengan pendekatan kultrual (pendidikan, budaya maupun psikologis) melalui taktik dakwah berupa tabligh, tarbiyah, tausyiah, ta'lim dengan media tatap muka langsung maka pada masa pandemi ini dakwah yang dilakukan dengan tatap muka langsung sulit untuk dilakukan dikarenakan adanya keharusan untuk social dan phyisical distancing.

Bila pada situasi normal aktifitas dakwah hanya menggunakan metode ceramah di masjid atau di majlis taklim, maka pada masa pandemi ini da'iyyah harus membuat strategi dan manajemen dakwah yang berbeda. Da'iyyah harus mengenali kompetensi internal dan kompetensi eksternal dulu dalam diri nya sebagai langkah awal yang harus dilakukan kemudian menggali potensi,pengetahuan dan ketrampilan yang dibutuhkan. Halhal yang termasuk kompetensi internal yaitu motivasi dakwahnya, karakter kerpibadian nya,kualitas iman nya .Sedangkan kompetensi eksternal yaitu pemahaman ilmu agama nya, pengetahuan ilmu dakwah nya, interaksi dengan jamaah serta lembaga dakwah, kemampuan mengaji dan hafalan al-Quran nya, skill komunikasi nya dan lain sebagai nya. Upaya ini agar bisa mengoptimalkan kompetensi dalam diri nya dan mendukung daya dakwah nya. Da'iyyah harus kreatif dan inovatif dalam dakwah dengan memanfaatkan kemajuan teknologi komunikasi dan media sosial yang semakin luas dan beragam .

Di antara upaya-upaya untuk mengoptimalkan kompetensi da'iyyah di masa pandemi yaitu: 
1. Kompetensi Internal Kompetensi Internal

Setelah da'iyyah memahami kompetensi internalnya, maka da'iyyah mempertimbangkan aspek mana saja yang harus distimulus dan bagaimana lebih menguatkan lagi supaya menjadi daya dorong dalam berdakwah.seperti motivasi \& niat berdakwah karena Allah SWT yang merupakan pondasi utama dalam aktifitas dakwah. Da'iyyah memantapkan tekad istiqomah berdakwah walaupun kondisi sedang pandemi.dan banyak kendala atau tantangan yang harus dihadapi. Da'iyyah harus meningkatkan kualitas dan kuantitas ibadah nya serta memperkuat juga hubungan interaksi nya dengan Allah SWT memohon pertolongan Allah dalam mengemban amanah dakwah . Da'iyyah perlu juga memperbaiki karakter nya lebih ramah,lebih sabar dan terbuka menyikapi perubahan zaman.

2. Kompetensi Ekternal

Kemampuan eksternal yang harus ditingkatkan oleh seorang da'iyyah di antara nya bidang tekonologi komunikasi, media digital dan media sosial. Di masa pandemi semua itu harus dilatih dan di kembangkan menjadi sebuah keahlian dan sarana dakwah. Selain itu da'iyyah harus meningkatkan kemampuan komunikasi, menulis dan public speakingnya mengingat banyak sarana yang bisa digunakan lewat media sosial dan media digital. Media Dakwah digital harus menjadi saluran dakwah para da'iyyah karena saat ini sudah melekat menjadi bagian dari kehidupan masyarakat, terutama dakwah melalui media tayangan video di sosial media seperti youtube, instagram, facebook, twitter dan lain nya Da'iyyah bisa mengisi konten konten Islami secara menarik dan mudah di fahami. Dengan menggunakan media sosial, dan media digital untuk berdakwah sebagai salah satu upaya untuk menjaga Keselamatan para da'iyyah agar terhindar dari penularan covid 19 dan da'iyyah tetap bisa 
melaksanakan tugas nya di rumah mendidik anak-anak nya serta mendampingi suami nya.

\section{Daftar Pustaka}

Aliyah \& AS, Enjang 2009, Dasar-dasar Ilmu Dakwah, Bandung : Widya Padjadjaran,

Azis, Abdul, 1995, Yang Tegar di Jalan Dakwah, Jakarta: Gaya Media Pratama

Hasmy, 1994, Dustur Dakwah Menurut Al-Qur'an, Jakarta: Bulan Bintang

Iswandi Syahputra, 2007, Komunikasi Profetik: Konsep Dan Pendekatan Bandung: Refika Offset,

Jhon M. Echols \& Hasan Sadily, 1983, Kamus Inggris Indonesia, Jakarta: PT Gramedia, 1983

Rahmat, Jalaluddin, 1998, Psikologi Komunikasi Bandung: Rosdakarya 


\title{
PANDEMI, QOLBU, 'BEDUK' \& KETAATAN MAHLUK
}

\author{
Supriadi, MM. ${ }^{12}$
}

(STAI Bumi Silampari)

"Ketahuilah, di dalam jasad, ada segumpal daging. Jika ia baik, maka baik pula seluruh jasad. Jika itu rusak, maka rusak pula seluruh jasad. Ketahuilah bahwa itu adalah hati/'Qolbu' (HR.

Bukhari nomor 52 dan HR. Muslim nomor 1599)"

Setiap kita tentulah mengenal dan mengetahui suara ataupun surau, sebagai pertanda masuknya waktu shalat bukan hanya sebelum masa pendemi covid 19 berlangsung tetapi jauh dari beberapa tahun yang lalu. Pada beberapa tempat, penggunaan beduk juga ada yang menjadikan sebagai tanda "adanya orang yang meninggal / kematian". Sekitar tahun 2000 -an, penulis (kala itu penulis sedang menempuh strata satu di Universitas Sriwijaya) pernah mengikuti kegiatan Student Work Camp (SWC) yang diadakan organisasi mahasiswa bertujuan untuk kegiatan sosial kemasyarakatan bertempat di salah satu desa di kaki Gunung tertinggi yang ada di Sumatera Selatan diikuti dari berbagai utusan mahasiswa berasal dari perguruan tinggi yang berada di Sumsel.

Suatu hari setelah melakukan kegiatan sosial 'mengajar anak-anak sekolah dasar", Penulis dan beberapa peserta $S W C$

12 Penulis lahir di Palembang, 13 September 1980, penulis merupakan Dosen di STAI Bumi Silampari dalam bidang ilmu Kewirausahaan dan Jurnalistik, penulis menyelesaikan gelar Sarjana di Universitas Sriwijaya (2005), sedangkan gelar Magister Manajemen diselesaikan di Universitas Bina Insan Lubuklinggau (2017), dan sekarang sedang menempuh program Doktoral Program Studi Manajemen Pendidikan Islam (MPI) di Universitas Islam Negeri Sultan Thaha Saifuddin Jambi. 
hendak melaksanakan shalat ashar di masjid yang ada di desa tersebut. Karena memang sehari-hari, masyarakat beraktivitas di kebun maka masjid tampak sepi. Ketika waktu ashar tiba, penulis memukul "beduk" yang ada di masjid sebagai pertanda waktu shalat ashar tiba. Setelah menabuh beduk selesai, tiba-tiba masjid menjadi sangat ramai, dengan berdatangan nya masyarakat yang sambil bertanya siapa kah orang yang meninggal dunia / siapa yang "mati" pada sore itu. Ternyata fungsi beduk di masjid tidak hanya dijadikan sebagai pengingat waktu shalat tetapi juga sebagai pusat informasi atau sebagai tanda lain yang telah disepakati bersama oleh masyarakat. Beduk yang digunakan pada masjid desa tersebut digunakan pada waktu menunjukkan waktu untuk shalat maghrib, waktu shalat isya serta waktu shalat subuh dan waktu ketika akan melaksanakan shalat jum'at agar para laki-laki yang ada di kebun pulang dan melakukan persiapan shalat jum'at. Alhasil penulis pun "disidang" pada sore itu.

Dalam dunia ketaatan yang nyata sesungguhnya Qolbu kita atau lebih dikenal dengan Qolbu adalah beduk yang sesunggunya sebagai pengingat waktu kehidupan kita, beduk ketaatan kita kepada Alloh Subhanallahuwata'ala.

Saat ini, kehidupan dunia ini, setidaknya sudah terbagi menjadi dua kehidupan yakni kehidupan dunia aktivitas sehari-hari dan kehidupan di dunia maya/media sosial (medsos). Dalam kehidupan, selain manusia, alam dan mahluk selain manusia dengan berbagai istilah yang ada.

Kehidupan dunia fisik kita peroleh sejak kita dilahirkan oleh ibu kita, melalui sebuah keluarga yang ada. Kehidupan dunia akal dimulai saat kita memasuki masa 'akil balik', mengetahui mana salah mana benar, mengetahui mana yang baik dan mana yang kurang baik.

Kehidupan dunia ini sesungguhnya hanya tempat senda gurau semata. Secara filosofi, kehidupan kita yang bebas, dibatasi oleh kebebasan individu lain yang ada serta 
keberadaan alam yang ada di sekitar kita yang juga memiliki kehidupannya. Tentu saja, sebagai seorang muslim, tentu memahami bahwa semua kehidupan di dunia adalah untuk dan dalam rangka beribadah kepada Alloh Subhanallahuwata'ala. Sehingga kita wajib mengenal diri, jati diri, dan siapa diri yang telah dapat berada di kehidupan dunia dengan izin Alloh Subhanallahuwata'ala.

\section{Qolbu sebagai Beduk Ketaatan}

Saat ini banyak terjadi kasus yang jauh dari bisa dikatakan bermoral. Mulai dari kasus penyalahgunaan narkotika dan obat terlarang, pencurian, asusila, penyimpangan perilaku seksual dan kasus lainnya yang ada di tengah masyarakat kita meski dalam kondisi pandemi covid 19.

Persoalaan moral adalah masalah sangat penting bagi setiap individu dan bagi setiap bangsa. Kalau moral sudah rusak, maka kehormatan dan ketentraman bangsa itu akan hilang. Untuk memelihara kelangsungan hidup secara wajar, maka perlu sekali adanya moral yang baik. Qolbu adalah sintesis dari segala motif prilaku dan perkataan seseorang dan hakikat. Seperti apa rupa atau penampakan hati seseorang tercermin dari segala sesuatu yang dikatakan dan dilakukan seseorang (Sugiharto, 2018). Begitu juga dengan bentuk ketaatan seseorang terhadap tuhanya akan menunjukan hal kebaikan yang sifatnya akan kekal, hakiki dan abadi.

Ketaatan hakiki akan kita peroleh ketika kita mengenal siapa sesungguhnya kita. Beribadah, seperti halnya shalat, puasa, zakat, dan lainnya seyogyanya sudah bisa diingatkan oleh sang beduk pengingat ketaatan yaitu Qolbu. Suara soudsystem masjid yang memutarkan ceramah terkadang 30 menit sebelum waktu shalat, untuk di beberapa tempat mungkin sudah bukan masalah (misalnya lingkungan psantren, dan lainnya) tetapi untuk di bebarapa tempat lain, berkemungkinan besar sangat menganggu karena suara yang besar membuat telingga terganggu atau jika ada anak bayi, 
anak tersebut terbagun dari tidurnya yang nyenyak atau ada orang tua yang sedang sakit perlu waktu istirahat yang cukup. Ditambah lagi kaset/compact disc (CD) yang diputar sudah 'rusak' terkadang suaranya terdengar terkadang hilang, lalu terdengar lagi dan hilang lagi.

Seyogyanya qolbu lah yang mengingatkan tentang keberadaan kita, Qolbu yang mengingatkan ketaatan kita, Qolbu yang memberi tahu kapan waktu nya shalat subuh, shalat dzuhur, shalat ashar, shalat maghrib, shalat isya, bahkan shalat tahajud dan shalat sunnah lainnya. Begitu juga dengan ketika waktu berpuasa di bulan ramadhan, bukan orang lain yang mengingatkan kita sedang berpuasa tetapi diri kita sendiri yang mengingatkan kita sedang berpuasa. Qolbu adalah ibarat cermin, Qolbu merupakan tempat untuk mengevaluasi, mengukur tentang segala hal buruk atau baik, dan Qolbu akan berkata kebenaran tidak dapat dibohongi meski kita mencoba 'merasionalkan' perbuatan tidak baik menjadi seperti baik, maka Qolbu tetap akan mengatakan itu adalah tidak baik (Suparlan, 2015).

Qolbu merupakan tempat bergantungnya keburukan sebagaimana bergantungnya keimanan. Qolbu adalah rahasia dari rahasia yang tidak diketahui hakikatnya yang tersembunyi didalamnya, kecuali oleh Alloh Subhanallahuwa ta'ala. Karenanya, aqidah yang dimiliki oleh seorang muslim disertai segala yang dikerjakannya, apakah yang buruk ataupun yang baik, semuanya akan merujuk pada qolbu.

KH Toto Tasmara mengatakan bahwa Qolbu sebagai pusat kecerdasan ruhani.. Qolbu adalah ruh kebenaran, suatu bentuk mahabbah kepada Alloh Subhanallahuwa ta'ala. Kecerdasan ruhani dan aktualisasi cinta dalam Qolbi bias dilakukan dengan pelatihan / riyadhoh, mujahadah, muhasabah (perhitungan), muraqabah (meneliti diri), kesadaran akan kebutuhan shalat, serta melakukan amal shaleh dan ikhtiar dimama saja dan kapan saja, baik pada saat berdiri, duduk, maupun berbaring (Tasmara, 2001). 
Oleh karena nya mari jadikan beduk ketaatan kita dengan mengoptimalkan Qolbu yang dimiliki. Sebaik-baik Qolbu adalah untuk taat kepada Alloh Subhanallahuwa ta'ala. Alloh Subhanallahuwa ta'ala berfirman dalam Al-Qur'an Surah AlHajj ayat ke empat puluh enam yang artinya" Sesungguhnya bukan mata yang buta, tetapi yang buta ialah Qolbu yang di dalam dada".

\section{Daftar Pustaka}

Sugiharto, M. A. (2018). Materi Pendidikan Qolbu Menurut Hamka Dalam Buku Tasawuf Modern. Universitas Islam Negeri Raden Intan Lampung.

Suparlan. (2015). Mendidik Hati Membentuk Karakter. Pustaka Pelajar.

Tasmara, Toto, Haji. 2001. Transcendental Intelligence. Jakarta. Gema Insani Press. 


\title{
TAHAMMUL ILMI DI MASA PANDEMI
}

\author{
Dr. Fikfik Taufik, S.S, M.Sy. ${ }^{13}$ \\ (Universitas Muhammadiyah Bandung)
}

\begin{abstract}
"Rekaman digital yang dapat pula dijadikan sebagai wasilah ilmu yang sah dan tidak perlu lagi dianggap negatif. Bahkan seharusnya dimanfaakan sebaik-baiknya untuk menyebarkan agama Islam di sama pandemi ini"
\end{abstract}

$\mathrm{B}$ elajar merupakan satu keniscayaan. Sejak lahir manusia sudah dipertemukan dengan momen belajar, mulai dari belajar menggenggam, merangkak, berjalan, bahkan mengenal lingkungan yang ada di sekitar merupakan bentuk belajar dalam arti "usaha" untuk tahu dan mampu. Hal itu karena manusia lahir dengan ketidaktahuan dan ketidakmampuan. Umar bin Abdul Aziz pernah melantunkan syair.

$$
\text { تعلم فليس المرء يولد عالما }
$$

Belajarlah karena tidak ada orang yang lahir dalam keadaan berilmu

Dan tidaklah sama antara orang yang berilmu dengan orang yang bodoh.

Pembedaan antara orang yang jahil dengan orang yang berilmu dalam syair tersebut bukan semata pembedaan

13 Dr. Fikfik Taufik, S.S., M.Sy adalah Dosen di Universitas Muhammadiyah Bandung, Anggota Badan Hisab dan Rukyat Daerah Jawa Barat, serta Pengurus Yayasan Dakwah Islam al-Fatwa Bandung. Pendidikan S1 ditempuh di Universita Padjadjaran jurusan Sastra Arab, dilanjutkan S2 dan S3 di UIN Sunan Gunung Djati Bandung. 
kualitas masing-masing, tetapi juga pembedaan derajat mereka di sisi Allah SWT. Allah berfirman dalam surat azzumar ayat 9 bahwa tidaklah sama antara orang yang berilmu dengan orang yang tidak berilmu. Allah pun berjanji dalam surat al-Mujadilah ayat 11 akan mengangkat derajat orang yang mencari ilmu. Maka, syahdan! Kemajuan peradaban umat Islam, bahkan peradaban manusia, itu lahir dari "rahim" belajar.

Belajar merupakan proses untuk mendapatkan tahu dan mendapatkan mampu. Metode belajar atau cara untuk mendapatkan ilmu itu bermacam-macam. Mungkin pendekatannya berbeda antara satu zaman dengan zaman yang lain, antara satu daerah dengan daerah yang lain.

Proses untuk memperoleh pengetahuan itu diistilahkan sebagai tahammul ilmi. Tahammul ilmi dalam khazanah keilmuan islam ada yang bersifat verbal dan literal bahkan sekarang dikenal media digital. Ini merupakan satu perkembangan yang layak untuk dimanfaatkan sebagai thuruq tahammul ilmi mengingat dengan wasilahnya proses transfer pengetahauan dan informasi seolah memangkas jarak dan waktu, lebih mudah, meskipun ada sebagian kalangan yang mempertanyakan validitas, otentistas dan legalitas tahammul ilmu-ilmu keislaman melalui media sosial dan digital.

\section{A. Pengertian dan Macam-macam Tahammul Ilmi}

Tahammul merupakan istilah pinjaman dari ilmu hadits. Maka untuk memahaminya pun akan dipakai pengertian tahammul dalam terminologi ilmu hadits. Tahammul / تحمل merupakan isim masdar dari kata تحمل يتحمل/tahammala yatahammalu/. Padanannya dalam bahasa Indonesia adalah memikul, membawa, menghapal, mengandung, menyimpan (Munawwir, 1997). Tahammul pun diartikan sebagai الاخذ

عن الغير terminologi ilmu hadits ialah (Thahhan, 1415H)

$$
\text { بيان طرق أخذه وتلقيه عن الثيوخ }
$$


"Tahammul artinya penjelasan tentang cara mengambil dan menerima hadits dari guru."

$$
\text { هُوَ أخذ الْحَيْيث عَنْ الثَيخ بطريق من طرق التحمل }
$$

"Tahammul adalah proses menerima hadits (baca: ilmu) dari seorang guru dengan menggunakan satu dari beberapa metode." (Mahir al-Fahl)

Kedua definisi di atas memberikan gambaran proses ilmu itu didapat khususnya ilmu hadits. Ilmu hadits mengenal beberapa cara dalam belajar atau menerima atau juga mengambil hadits khususnya dan umumnya ilmu-ilmu keislaman, sehingga kemudian dikenal yang namanya sanad ilmu, yaitu jalur transmisi satu ilmu mulai dari pencetusnya sampai kepada orang yang terakhir menerima ilmu tersebut.

Metode atau thuruq tahammul yang dikenal dalam khazanah keilmuan islam adalah di antara nya sima', qira 'ah, kitabah, ijazah, wijadah, dan sebagainya. As-Sima' (mendengarkan) contohnya yaitu, seorang rawi mendengarkan sendiri secara langsung dari syaikh saat syaikh membacakan hadits. Al-Qira'ah artinya membaca. Maksudnya adalah seorang membaca suatu hadits di depan gurunya baik dari hapalan maupun tulisan yang ada di hadapannya, baik dia sendiri yang membacakan maupun orang lain. Ijazah yaitu pemberian izin dari guru kepada muridnya untuk meriwayatkan hadits/ilmu yang berasal darinya (guru). Ijazah seorang guru kepada murid bisa berupa hal yang didengar maupun yang tertulis atau berupa kitab. Saat ini istilah ijazah pun dikenal dan diadopsi dalam dunia pendidikan formal sebagai bukti tamat belajar di satu jenjang pendidikan. Ijazah ini cermin dari kelayalan seorang murid untuk mengajarkan kembali atau menerapkan ilmu yang telah diajarkan oleh gururnya.

Kitabah atau Al-Mukatabah, yaitu seorang guru menuliskan atau orang lain yang menuliskannya untuk diberikan kepada muridnya yang berada dalam satau tempat 
ataupun tidak. Bentuk ini merupakan satu contoh pengajaran ilmu dari jarak jauh atau transfer informasi dari jarak jauh melalui media tulisan atau dulu dikenal dengan surat menyurat. Selain dalam ilmu hadits, mukatabah pun pernah dilakukan oleh Imam asy-Syafi'i. Beliau menulis surat untuk khalifah yang kemudian dikumpulkan yang sekarang terhimpun dalam satu kitab yang diberi nama ar-Risalah. Bahkan praktek menulis surat ini pun pernah dilakukan oleh Rasulullah ketika mendakwahi raja-raja Persia dan Romawi. Kitabah, dalam konteks saat ini dapat pula berupa media digital.

Selanjutnya al-wijadah, yaitu seorang memperoleh/menemukan hadits orang lain dengan mempelajari kitab-kitab hadits dengan tidak melalui cara assima', al-ijazah, maupun yang lainnya. Misalnya, saya menemukan tulisan hadits seseorang, dia menuliskan, telah bercerita kepadaku si fulan, dan seterusnya. Wijadah ini merupakan satu bentuk belajar yang dapat disamakan dengan proses belajar otodidak. Yaitu seseorang membaca buku atau tulisan orang lain. Broadcast yang kita dapatkan sekarang bisa dikategorikan sebagai wijadah.

\section{B. Otentisitas dan Validitas Ilmu dalam Buku}

Otentisitas satu tulisan atau buku sebagai sumber ilmu merupakan hal yang tidak bisa dinafikan selama penisbatan buku kepada penulisnya benar, dan selama standar keilmiahannya dipertanggungjawabkan. Bahkan tulisan atau buku merupakan penguat ilmu. Indah sekali Imam Syafi'i menggambarkan (Usman bin Syatha al-Bakri)

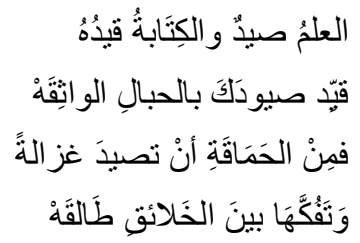


Ilmu itu seperti binatang buruan, dan tulisan adalah pengikatnya

Maka ikatlah buruanmu itu dengan tali yang kuat.

Alangkah bodohnya orang yang berburu rusa

Lantas melepaskannya di antara kerumunan manusia.

Proses belajar otodidak bagi sebagian orang dianggap sebagai hal yang tabu sehingga ada ungkapan, barang siapa yang belajar melalui buku, maka syaithanlah gurunya. Padahal sejatinya buku merupakan wasilah bagi penulis untuk mentransfer ilmunya kepada para pembaca, sehingga tidak lain, ketika seseorang sedang membaca satu buku, maka dia sedang berguru kepada penulisnya. Belajar otodidak mungkin lepas dari "kekang" pemahaman bahwa belajar itu harus tatap muka dengan guru.

Jahizh menggambarkan keutaman buku dengan sangat indah dalam syairnya yang terkenal washful kitab.

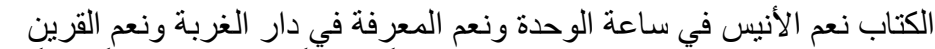

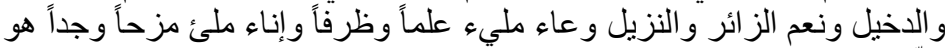

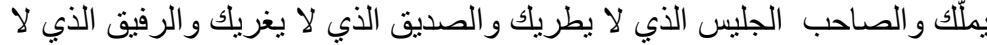
الذي لايريد استخر اج ما عندك بالملق و لايعاملك بالمكر و لايخدعك بالنفاق ولائل الايحتال

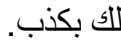

"Buku adalah teman terbaik di saat bersendirian, informasi terbaik di kota yang asing, sebaik-baik teman perjalan, dan teman untuk tinggal. Buku adalah satu wadah yang berisi banyak ilmu, tempat yang dipenuhi dengan canda dan kebajikan. Buku adalah teman duduk yang tidak akan merayumu dengan pujian, dan teman yang tidak akan mengelabuimu, tidak akan membuatmu bosan. Teman yang tidak menghendaki engkau mengeluarkan unek-unek, dan tidak pula bersikap kepadamu dengan makar dan tipu muslihat serta kemunafikan, tidak pula mendustaimu." 
Otentisitas, validitas, dan legalitas informasi melalui tulisan atau pun buku tergambar dalam hadits Nabi Muhammad SAW

$$
\text { " "ما حق امرئ مسلم له شيء يوصي فيه يبيت ليلتين إلا ووصيته مكتوبة عنده }
$$

Tidaklah yang menjadi kewajiban bagi setiap muslim untuk mewasiatkan sesuatu sebelum tidur kecuali wasiat tersebut ditulis. (HR. Al-Bukhari, Kitab al-Washaya)

Sekiranya tulisan tidak bisa dijadikan landasan informasi maka tidak mungkin Rasulullah SAW menyuruh menuliskan wasiat. Dalam riwayat lain dijelaskan,

$$
\text { وان النبي صلى الله عليه وسلم كان يبعث بكتبه ورسائله إلى الملوك و غير هم }
$$

Bahwa Nabi saw mengutus sahabatnya untuk mengirim surat (tulisan) kepada raja-raja dan yang lainnya. (AlBukhari Kitab al-Ahkam)

\section{Sanad Ilmu Digital}

Sanad ilmu menjadi budaya dalam khazanan keilmuan islam. Sanad menjadi patokan otentisitas, validitas, dan legalitas satu ilmu atau informasi dalam islam. Sanad merupakan jalur atau transmisi ilmu dari guru ke murid terus sampai ke sekian generasi. Sanad terdiri dari namanama periwayat (guru-murid) yang disertai dengan penjelasan bagaimana proses informasi/ilmu itu diterima oleh murid dari gurunya.

Proses mengambil dan menerima informasi dimaksud adalah yang sebelumnya sudah dijelaskan yaitu thuruq tahammul. Proses penyampaian ilmu yang akan dibahasa pada bagian ini adalah kitabah dan wijadah. Dua hal ini menjadi hal yang dianggap sesuai untuk menetapkan otensititas, validitas, dan legalitas ilmu di era digital. Broadcast yang disebar setelah dipertanggungjawabkan kebenarannya menjadi thuruq tahammul ilmu yang bisa 
menjadi sanad ilmu bagi setiap pembaca atau pun pendengar. Bahkan, video kajian keilmuan yang disebar, lebih otentitk daripada sekedar tulisan. Tingkatan tahammulnya mungkin sama dengan mendengar langsung gurunya.

Mungkin tidak masuk akal apabila di satu sisi dikatakan belajar dari media sosial, youtube atau apa pun itu tidak sah, atau tidak baik, atau apa pun stigma negatifnya, sedangkan di sisi lain, kajian-kajian keilmuan islam itu disebar seluasluasnya. Seolah kontaproduktif. Kalau pun belajar melalui media sosial itu tidak baik, kenapa kemudian video kajian keilmuan itu direkam dan disebarluaskan.

Bagaimana pun media sosial digital itu hanya sebagai wasilah tersampaikannya ilmu secara umum, namun secara prinsip kita tidak berguru pada media sosial tersebut, tetapi berguru pada orang yang menjadi narasumbernya. Perlu kiranya ditegaskan kembali bahwa tulisan atau pun video adalah representasi dari penulis atau pun narasumbernya. Ketika ditemukan video kajian keislaman, maka sama artinya dengan wijadah ilmu. Jika ilmu ditulis dan disebar, maka itu artinya tahammul ilmu dengan kitabah. Itulah sanad ilmu di era digital.

Pandemic sekarang mengharuskan kita mengubah pola dan budaya belajar, budaya kajian dan pengajian. Saat keharusan untuk menjauhi kerumunan yang mengahalangi belajar secara tatap muka, sedangkan ilmu harus terus disampaikan dan dipelajari, maka media sosial, atau pun platform-platform digital lain menjadi solusinya.

\section{Penutup}

Sanad ilmu itu berkembang sesuai dengan perkembangan zaman. Bermula dari era verbal dimana periwayatan langsung berlaku luas dan menjadi standar paling tinggi, kemudian tulisan diakui sebagai wasilah ilmu. Termasuk dalam hal ini adalah rekaman digital yang dapat pula dijadikan sebagai wasilah ilmu yang sah dan tidak perlu lagi dianggap negatif. Bahkan seharusnya dimanfaakan sebaik- 
baiknya untuk menyebarkan agama Islam di masa pandemi ini. Wallahu a'lam bi sh-shawab.

\section{Daftar Pustaka}

Munawwir, Ahmad Warson. Al-Munawwir, Kamus Arab Indonesia (Surabaya: Pustaka Progresif, 1997). h. 297

Thahhan, Mahmud, Taisir mushthalahul hadits, (Aleksandria, Markaz al-Huda li Dirasat: 1415 H) h. 121

Mahir al-Fahl. Buhuts fi al-Mushthalah. CD Maktabah Syamilah.

Usman bin Syatha al-Bakri. I'anathu ath-Thalibin fi hilli alfazhi fathu al-mu'in. CD Maktabah Syamilah.

HR. Al-Bukhari, Kitab al-Washaya. CD Maktabah Syamilah

Al-Bukhari Kitab al-Ahkam, bab Syahadah 'ala al-Khath 


\title{
PEMBIASAAN KARAKTER CINTA AL-QUR'AN BAGI ANAK DI MASA PANDEMI COVID-19
}

\author{
Irma Fauziah, M.Pd ${ }^{14}$ \\ (UIN SATU Tulungagung)
}

"Pada masa ini, anak harus dibekali dengan ajaran yang baik dengan menjadi generasi yang cinta Al-Qur'an dia mendapat kebaikan kebaikan dan berada dalam proses semata-mata untuk mencapai ridha Allah sebagai amalan dunia dan akhirat"

Karakter cinta Al-Qur'an adalah karakter dengan menghafal, serta memahami dengan baik dan benar makna yang terkandung di dalamnya serta menjadikan aktivitas quráni sebagai bagian dari kegiatan sehari-hari dengan penuh cinta. Cinta Al-Qur'an harus diajarkan sejak dini kepada anak sebagai ikhtiar membentuk akhlaqul karimah baik melalui pembiasaan di rumah maupun di sekolah. Permasalahannya adalah bahwa bagi anak-anak yang sedang belajar Alqur'an sebagai pemula seyogyanya didampingi oleh seorang guru atau ustadz/ustadzah karena banyak materimateri yang memerlukan contoh baik dalam makhorijul huruf, harakat, panjang pendek bacaan, hukum bacaan dan lain-lain. Maka bagaimana dalam kondisi Pandemi Covid 19 ini, yang mengharuskan anak belajar di rumah tanpa tatap muka dengan guru/ustadznya? Mengingat apabila dengan pembelajaran tatap muka baik di taman pendidikan Alquran

${ }^{14}$ Penulis lahir di Tulungagung, 30 Desember 1993, penulis merupakan Dosen UIN Sayyid Ali Rahmatullah Tulungagung dalam bidang Pendidikan Dasar di Jurusan Pendidikan Guru Madrasah Ibtidaiyah (PGMI), penulis menyelesaikan gelar Sarjana pendidikan dan Magister Pendidikan di IAIN Tulungagung. 
(TPQ), Madrasah Diniyah, ataupun di sekolah anak-anak bisa mendapatkan pembiasaan-pembiasaan yang terstruktur dan tersistem secara baik. Berikut beberapa strategi yang bisa diterapkan diantaranya;

\section{Koordinasi dengan dengan guru/ustadzah}

Guru dan orang tua adalah yang paling bertanggungjawab mendidik anak sebelum ia dewasa. Terlebih dimasa Pandemi Covid-19 ini anak-anak melaksanakan pembelajaran daring di rumah, maka sinergi guru dan orang ua harus semakin intensif. Dalam pembelajaran membaca dan menghafal Al-Qur'an, orang tua dan guru perlu mengkomunikasikan peran masingmasing supaya proses mengaji anak bisa maksimal. Misalnya dengan sistem yang disepakati tentang jadwal mengaji anak, tentang pendampingan orang tua dalam mengaji anak, tentang sarana yang dibutuhkan dalam mempersiapkan anak mengaji secara daring misalnya dengan zoom atau video call, tentang evaluasi guru terhadap proses mengaji anak dan lain-lain. Dengan koordinasi, orang tua dan guru bisa menentukan strategi terbaik demi menjaga kebiasaan belajar mengaji yang baik yang telah diterapkan di sekolah untuk diadaptasi di rumah.

\section{Memanfaatkan Aplikasi}

Pandemi Covid-19 mengubah seluruh tatanan kehidupan. Karena adanya kebiasaan jaga jarak, menuntut manusia untuk mengandalkan teknologi dan jaringan internet online untuk berinteraksi, komunikasi dan rekreasi sehingga intensitas penggunaan HP maupun laptop sangat tinggi, mulai dari belanja, sekolah, rapat, main game dan lain-lain. Tentunya keterampilan pemanfaatan teknologi ke arah dampak positif menjadi sangat penting. Salah satunya yakni pemanfaatan hadirnya berbagai aplikasi belajar membaca dan menghafalkan Al-Qur'an yang bisa dengan mudah di download di playstore. Hal ini sangat mudah dilakukan 
karena bisa digunakan hanya bermodalkan HP Android dan bisa di akses kapanpun dimanapun baik di rumah, dikantor, maupun di perjalanan selama HP dalam genggaman. Berikut beberapa aplikasi yang dapat diakses;

a. Qurán Kemenag

Qurán Kemenag adalah Aplikasi Mushaf AlQur'an digital yang dibuat oleh Kementerian Agama c.q Lajnah Pentashihan Mushaf Al-Qur'an. Ayat Alquran dalam aplikasi ini menggunakan Mushaf Standar Indonesia Rasm Usmani sehingga mudah dan familiar untuk dibaca. Tersedia dalam format Android, Web dan IOS. Disamping menyajikan teks Al-Qur'an lengkap 30 juz juga dilengkapi dengan terjemahan, tafsir, tahlil dan suara murattal Alquran Syekh Mahmud Khalil Al Husairy.

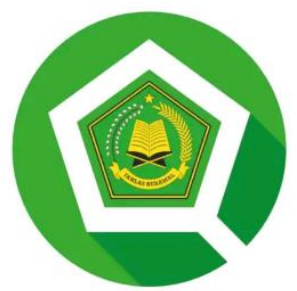

Gambar 1. Logo Quran Kemenag di Playstore

b. Iqró

Iqro'adalah aplikasi belajar Al-Qur'an yang tersedia dalam jilid 1-6 lengkap memuat pembelajaran Al-Qur'an mulai dari pengenalan huruf hija`iyah, belajar huruf sambung dengan bacaan panjang (mad thobi'i), belajar hukum bacaan nun sukun dan mim sukun dan seterusnya. Dalam aplikasi ini dilengkapi dengan gambar dan warna yang menarik untuk semua kalangan usia utamanya anak-anak. Aplikasi ini dapat digunakan di smartphone maupun tablet versi minimum Andorid 
4.1. Ukuran konten secara otomatis akan menyesuaikan layar secara proporsional sehingga memudahkan pembaca.

\section{c. Tilawati}

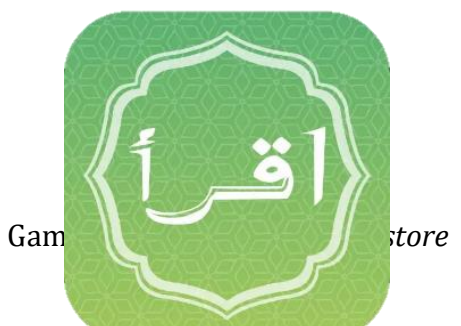

Tilawati merupakan aplikasi belajar membaca AlQur'an yang terdiri dari 6 jilid lengkap. Aplikasi mudah digunakan dan memiliki tampilan desain yang menarik untuk membangkitkan minat belajar anak-anak. Didalamnya terdapat audio murottal serta video pembelajaran yang bisa ditirukan dengan mudah lengkap dengan intonasinya.

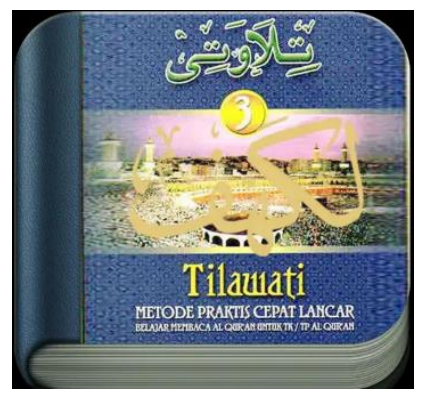

Gambar 3. Logo Tilawati di Playstore

d. Whatsapp

Dalam hal belajar Alquran, pemanfaatan Whatsapp yang sederhana dan privasi sangat membantu. Whatsapp memiliki fitur chat, panggilan dan video call yang dapat digunakan untuk setoran/sorogan Al-Qur'an kepada guru. Dengan 
video call, proses belajar Alquran tetap bisa dimaksimalkan karena guru bisa mendengar bacaan, melihat makhroj sekaligus bisa membetulkan apabila ada kesalahan. Dengan begitu, pembelajaran membaca dan menghafal Al-Qur'an bisa tetap dilakukan meskipun dengan daring.

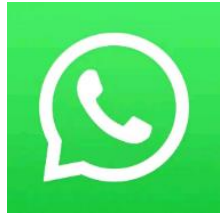

Gambar 4. Logo Whatsapp di Playstore

\section{Memberi Teladan}

Bandura berpendapat bahwa kepribadian merupakan produk dari tiga kekuatan yang saling berinteraksi yaitu lingkungan, perilaku, dan pikiran (Bandura, 2001). Lingkungan terdekat dengan peserta didik adalah orang tua dalam keluarga. Oleh karena itu, orang tua harus maju untuk memberikan teladan, orang tua yang dekat dengan Al-Qur'an akan menjadi contoh yang ditiru oleh anak-anaknya. Maka iklim cinta Al-Qur'an harus dibangun lebih dulu di lingkungan keluarga atas teladan dari orang tua. Contoh bentuk keteladanan cinta AlQur'an yang dilakukan orang tua dapat berupa teladan kebiasaan Tadarus Al-Qur'an ba'da maghrib, kebiasaan mendengarkan murottal Al-Qur'an yang di play di HP maupun speaker, teladan orang tua yang membaca alquran dengan tartil, dan lain-lain. Anak adalah seorang peniru ulung. Maka dari itu, orang tua harus membentuk dirinya sendiri sebagai profil uswah terbaik bagi anak-anaknya. 


\section{Disiplin dengan Membuat Jadwal}

Seperti halnya di TPQ, Madrasah atau sekolah, hendaknya anak disediakan waktu khusus untuk mempelajari, membaca atau menghafal Al-Qur'an, tentu disesuaikan dengan waktu dan kesiapan orang tua untuk mendampingi. Orang tua dapat membantu dengan mengusahakan kedisplinan anak melalui penyusunan jadwal mengaji. Dengan begitu pembiasaan yang sudah dijalankan di sekolah tidak luntur, hanya pindah tempat saja berganti di rumah. Misalnya apabila di sekolah terbiasa pagi pukul 08.00 WIB dimulai dengan tadarus Al-Qur'an dan surat pendek, atau ketika di TPQ terbiasa sorogan pada pukul 14.00 sampai áshar, maka kebiasaan tersebut bisa diterapkan dirumah bersama orang tua. Sebagaimana definisi displin yang berarti sikap mental mau bertindak sesuai aturan dengan sukarela, maka ketika jadwal ini dilaksanakan dengan baik, akan membentuk sebuah paradigma bagi anak bahwa membaca Al-Qur'an adalah bagian kebutuhannya diantara 24 jam kegiatan kesehariannya.

\section{Memberikan Motivasi dan Apreasiasi}

Abraham Maslow membagi kebutuhan manusia dalam lima hirarki, yaitu kebutuhan fisik, rasa aman, kepemilikan dan rasa cinta, perasaan dihargai, dan aktualisasi diri (Maslow, dalam Schultz, 1991). Perasaan dihargai /apresiasi terhadap kemampuan, dan pencapaian sangat berharga bagi perkembangan anak. Hal itu akan menumbuhkan motivasi internal pada diri anak untuk terus mau belajar karena mengetahui orangorang terdekat memperhatikan dan mendukungnya. Misalnya dengan memuji anak ketika berhasil menghafal juz ámma, ketika makhroj anak semakin fashih, ketika anak telah memahami tanda baca/harakat, ketika anak naik dari jilid ke bacaan juz, ketika anak mau nderes atas inisiatif sendiri dan lain-lain. Bahkan bila perlu pemberian reward juga perlu dilakukan. 
Selain itu orang tua memberikan motivasi-motivasi tentang keutamaan belajar Al-Qur'an. Menjelaskan bahwa orang yang paling baik adalah orang yang belajar Alquran sebagaimana Hadits Rasulullah SAW;

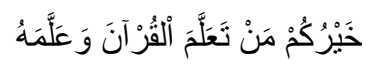

"Artinya: Sebaik-baik orang di antata kamu adalah orang yang belajar Alquran dan mengajarkannya."

Pada masa ini, anak harus dibekali dengan ajaran yang baik sehingga ia mengetahui dan menyadari bahwa dengan menjadi generasi yang cinta Al-Qur'an dia mendapat kebaikan kebaikan dan berada dalam proses semata-mata untuk mencapai ridha Allah sebagai amalan dunia dan akhirat. Mengupayakan Cinta AlQur'an bagi anak adalah sebuah refleksi, kesempatan dan hikmah yang bisa kita perjuangkan dalam kehidupan berdampingan dengan Pandemi Covid 19 ini.

\section{Daftar Pustaka}

Bandura, A. 2001. Social cognitive theory: An agentic perspective. Annual Reviews Psychology

Duane Schultz. 1991. Psikologi Pertumbuhan: Model-Model Kepribadian Sehat, terj. Yustinus. Yogyakarta: Kanisius. 


\title{
THE POWER OF “GRACIA" REFLEKSI ATAS PENGALAMAN SEBAGAI PENYINTAS COVID-19
}

\author{
Dr. Jonas Klemens G.D.Gobang, S.Fil.,M.A. ${ }^{15}$ \\ (Universitas Nusa Nipa Indonesia - Maumere, Flores, NTT)
}

"Saya sungguh merasakan bahwa saya mengalami rahmat besar dari Tuhan. Tuhan lah yang memberi saya Gracia dan akan tetap memberikannya untuk saya dan untuk siapa saja di muka bumi ini"

\begin{abstract}
Caya tinggal di sebuah pulau bernama Flores. Flores itu adalah nama yang diberi oleh Bangsa Portugis dari frasa capo de Flores, artinya Pulau Bunga. Nama asli Pulau Flores sesungguhnya adalah Nusa Nipa, artinya Pulau Naga. Penduduk Pulau Naga tidak luput dari serangan bisu tapi terbukti ganas karena mampu menghilangkan nyawa manusia, virus bernama corona. Corona artinya mahkota. Saya termasuk salah satu dari sekian banyak penduduk bumi ini yang terpapar virus corona. Lantas mengapa saya memberi judul refleksi atas pengalaman saya terpapar, bergejala dan mengalami sakit akibat covid-19, The Power of Gracia?
\end{abstract}

Nomen est omen. Nama adalah tanda, kata adagium Latin tersebut. The power of Gracia sebagai sebuah judul refleksi

15 Dr. Jonas Klemens Gregorius Dori Gobang, S.Fil.,M.A., adalah dosen pada Program Studi Ilmu Komunikasi Universitas Nusa Nipa Indonesia. Lulusan S1 Filsafat pada Sekolah Tinggi Filsafat Katolik (STFK) Ledalero tahun 1999. Melanjutkan studi S2 bidang Ilmu Komunikasi pada Universitas Gadjah Mada Yogyakarta pada tahun 2009 - 2011. Pada tahun 2012 melanjutkan studi S3 (doktoral) bidang Ilmu Komunikasi pada Universitas Padjadjaran Bandung hingga lulus tahun 2015. Sejak tahun 2014 menjabat sebagai wakil rektor I bidang Akademik pada Universitas Nusa Nipa Indonesia. 
atas pengalaman saya sebagai penderita covid-19 tentu memiliki tanda atau makna tertentu. The power of Gracia atau kekuatan Gracia. Gracia atau Gratia artinya rahmat. Kata yang bermakna rahmat ini sudah lama menginspirasi saya sehingga ketika anak saya semata wayang lahir ke bumi, saya memberinya nama Gracia. Saya sungguh merasakan bahwa saya mengalami rahmat besar dari Tuhan. Tuhan lah yang memberi saya Gracia dan akan tetap memberikannya untuk saya dan untuk siapa saja di muka bumi ini. Mengapa harus ada kekuatan rahmat atau the power of Gracia ketika saya sedang bergulat dengan virus corona?

Gracia adalah rahmat yang saya peroleh dengan cumacuma dari Tuhan. Cara Tuhan menolong saya melalui sesama, mulai dari istri yang setia merawat, anak saya yang bernama Gracia pun dalam kegalauannya karena takut kalau ayahnya "gugur" melawan covid-19 selalu mengucap doa setiap malam seiring deraian air matanya yang terus mengalir menganak sungai di kedua pipinya yang masih polos. Mamanya memberi ia kekuatan bahwa dalam situasi "terbatas", mereka harus tekun berdoa agar Tuhan memberikan rahmat penyembuhan kepada suami dan ayah mereka yang sedang terbaring sakit di kamar yang lain. Saya harus berpisah kamar dengan istri dan anak saya yang masih berusia 7 tahun. Situasi ketika saya dinyatakan positif covid19 melalui rapid test dan selanjutnya polymerase chain reaction test $(P C R)$ adalah situasi terbatas. Semua serba terbatas. Obat terbatas. Komunikasi dengan orang yang paling dekat sekalipun harus terbatas karena dibatasi oleh jarak protokol yang dianjurkan. Ruang gerak saya pun menjadi terbatas. Bahkan asupan makan, minum dan oksigen nyaris terbatas jika saya tidak berjuang mengatasinya. Saya dipaksa harus makan dan minum walau sesungguhnya sangat sulit untuk menelan makanan seenak apapun yang telah disiapkan istri. Di rumah, kami hanya bertiga. Saya, Yuliana, istri saya dan Gracia, anak kami. Beruntung saya masih bisa menarik nafas kendati agak sesak. Tabung oksigen 
yang diupayakan oleh sahabat saya Harry Japira gagal dibawanya ke rumah saya sebab petugas yang ditunjuk untuk membantu secara sukarela mengurungkan niatnya untuk membantu saya. Situasi menjadi serba terbatas.

Dalam situasi terbatas ini, saya masih berharap kiranya ada rahmat Tuhan yang bekerja melalui siapa saja. Sudah pasti istri saya sigap kendati saya dan dia harus hati-hati jika istri terjangkit virus dari saya dan anak kami Gracia pasti akan terjangkit juga. Satu-satunya yang kami harapkan hanyalah rahmat Tuhan yang bekerja untuk kami. Setiap malam Gracia anak saya selalu menangis karena ia tidak mau saya tinggalkan mereka dan tidur terpisah dengan dia dan mamanya di bilik atau kamar yang lain. Saya harus taat pada protokol kesehatan. Dokter Clara Francis, jurubicara Satgas Covid-19 Kabupaten Sikka mengingatkan saya melalui telepon dan pesan Whatsapp. Saya selalu tidak tega ketika mendengar tangis Gracia setiap malam. Saya nekat menghiburnya. Dengan menggunakan masker, saya mendatangi kamar mereka. Saya pastikan dan yakinkan Gracia bahwa saya pasti sembuh dan tidak akan pergi meninggalkannya. Saya sabar menunggu hingga Gracia terlelap tidur. Saya ucapkan doa singkat ketika ia Gracia, anak saya itu sudah terlelap. Tuhan beri kami rahmat terutama rahmat kesembuhan dari covid-19 dan lindungi istri saya Yuliana dan anak saya Gracia, agar mereka tidak terpapar virus dari saya. Setiap malam doa singkat ini saya ucapkan tatkala Gracia sudah terlelap.

Tuhan pun menjawab doa saya yang sederhana itu. Ia mencurahkan rahmat-Nya yang dahsyat kepada saya. Saya berangsur membaik di hari ke-6, ke-7 hingga hari ke-10 sampai hari ke-14. Rupanya anak saya juga tahu siklus inkubasi virus karena ketika pandemi melanda hampir semua wilayah bumi dan saat masa WFH ia selalu menonton berita terkait covid-19 di televisi. Anak sekecil itu pun tahu kalau penderita covid-19 akan pulih jika ia mampu bertahan melalui isolasi mandiri dan asupan nutrisi, vitamin dan 
protein melalui makanan dan minuman serta obat-obatan seperti paracetamol, antibiotik selama 14 hari bahkan 10 hari sudah bisa dinyatakan sembuh. Di hari ke-14, Gracia sudah nekat masuk ke kamar isolasi dan meminta untuk dipeluk. Covid-19 tidak hanya memaksa orang untuk menjaga jarak intim dan jarak sosial (prosemik) tetapi mampu memisahkam kita dari yang lain di bumi ini.

\section{Up and Down Panas Suhu Tubuh ini}

Harry Japira sahabat, rekan dosen, Dekan Fakultas Teknik Universitas Nusa Nipa (UNIPA) Indonesia, owner Apotek K24 Maumere selalu memantau perkembangan saya selama saya bergulat dengan virus corona. Saya menjadi sedikit paham tentang setiap gejala dan reaksi tubuh saya dari hari ke hari bahkan dari menit ke menit. Harry tidak hanya membuat resep obat melawan virus corona yang ia minta agar saya konsultasikan juga dengan dokter Clara Francis, dokter sekaligus jurubicara Satgas Covid-19 Kabupaten Sikka. Harry mengirimkan buat saya, oxymeter untuk mengukur denyut jantung dan terutama mengukur kadar oksigen dalam darah saya. Ia berpesan agar saya terus memantau saturasi saya dari menit ke menit. Harry cukup mencemaskan keadaan saya. Spirit solidaritasnya sangat nyata dapat saya rasakan. Solidaritas otentik yang riil. Bukan sekadar solidaritas yang kerap diwacanakan di berbagai momentum atau media. Di saat yang "terbatas" ini, penderita covid-19 lebih membutuhkan solidaritas otentik. Solidaritas absolut untuk berpihak pada kehidupan seseorang yang sedang bergelut dengan kondisi up and down baik secara fisik maupun moril. Bayangan akan kematian ada di depan mata dan pikiran kita tatkala hampir setiap hari kita mendengar raungan sirene dari mobil ambulans baik yang lewat di jalan raya depan rumah atau yang terdengar dari berita televisi atau berita live secara online.

Dalam kondisi up and down, saya seperti merasakan adanya "Gracia" entah dari orang-orang yang peduli seperti Harry Japira dan Drs. Sabinus Nabu, Ketua Yayasan 
Pendidikan Tinggi Nusa Nipa, "orang tua” kami di Kampus UNIPA Indonesia, yang saya tahu setiap hari mengucap doa, memohon kepada Tuhan agar Tuhan oleh karena Kasih-Nya memberikan rahmat kesembuhan buat saya, maupun dari Gracia-ku yang ketika pagi tiba hingga sore menjelang malam pun tiba, ia berada di balik kaca jendela, menatap ayahnya yang terbaring di ranjang sakit akibat terpapar covid-19. Dalam hatinya ia selalu menghitung hari. Mata kami saling bertemu, ketika saya berpaling ke arah kaca jendela bening dari ranjang sakit. Saya melihat dua bola mata yang bening, polos seolah sedang memancarkan rahmat kesembuhan. Aliran rahmat kesembuhan kuat terasa ketika dari mulut mungilnya itu tersungging senyumannya yang manis tapi menyimpan getir seolah berharap cemas, cepat sembuh ayah! Sungguh sebuah aksi yang melebihi obat yang paling mujarab sekalipun. Saya menjadi sadar bahwa dalam kondisi up and down ini, solidaritas otentik adalah "obat" yang mujarab.

\section{Ketidakpastian dan Upaya Menguranginya}

Pandemi covid-19 yang melanda bumi ini menimbulkan banyak ketidakpastian. Ada banyak ketidakpastian dalam situasi pandemi ini. Kondisi ekonomi yang tidak menentu akibat pembatasan sosial pasca positif covid-19 menimbulkan ketidakpastian. Ketidakpastian juga terjadi manakala adanya pasien positif covid-19 diumumkan pemerintah, entah bagaimana keadaan yang akan terjadi di masa depan. Untuk mengurangi ketidakpastian di masa pasca positif covid-19 ini perlu dibangun pola komunikasi kesehatan yang mendorong tercapainya keadaan atau status yang sehat secara utuh, baik fisik, mental, maupun sosial.

Gagasan kecil tersebut di atas pernah saya tuangkan dalam sebuah artikel sederhana ketika diminta oleh Rektor Universitas Nusa Nipa, Dr. Ir. Angelinus Vincentius, M.Si dan Ketua Yayasan Pendidikan Tinggi Nusa Nipa, Drs. Sabinus Nabu untuk menjadi koordinator Tim Peduli Covid-19 Kampus UNIPA Indonesia. Saya bersama teman-teman dosen dari berbagai program studi menggagas webinar selama 
empat kali di awal pandemi melanda Republik Indonesia. Tim Peduli Covid-19 UNIPA Indonesia bertugas membantu pimpinan universitas dan yayasan untuk menerapkan protokol kesehatan di kampus. Semua kegiatan ini saya jalani dengan penuh semangat bersama teman-teman. Kami berikhtiar untuk memberikan kepastian di tengah arus ketidakpastian yang mulai menggelora ketika pandemi covid19 melanda.

Tim Peduli Covid-19 UNIPA Indonesia berupaya mensinergikan semua komponen dari ke-13 program studi yang ada di kampus untuk melakukan mitigasi bencana covid-19 ini. UNIPA Indonesia memiliki Program Studi Keperawatan dan Profesi Ners, Ilmu Komunikasi, Psikologi, Manajemen, Akuntansi, Agribisnis, Agroteknologi, Manajemen Sumberdaya Perairan, Informatika, Teknik Sipil, Arsitektur, Pendidikan Kimia, Pendidikan Fisika, Pendidikan Biologi, PGSD, Pendidikan Bahasa Inggris dan Hukum. Semua komponen dari sumberdaya yang ada di Kampus UNIPA Indonesia kami padukan untuk mengusahakan solidaritas di tengah pandemi covid-19. Kami berupaya mengotentikkan solidaritas kendati harus jujur untuk mengatakan bahwa masih ada keterbatasan karena si virus tidak memandang bulu. Sehebat apa pun tim, kami dapat juga terpapar virus corona. Dan benar, saya pun terpapar covid-19, entah dari siapa dan persisnya di mana.

Demikian pun seperti yang diberitakan oleh berbagai media cetak dan elektronik bahwa banyak dokter dan perawat di setiap fasilitas kesehatan juga terpapar virus yang dapat mematikan ini. Bahkan mereka, para tenaga kesehatan (nakes itu sudah memiliki standar operasional prosedur penanganan pasien covid-19, dilindungi juga oleh alat pelindung diri (APD) yang khusus, masih ada bahkan banyak juga yang tewas terpapar virus ini. Bukankah keadaan ini membuat semakin hebatnya ketidakpastian. Lantas kita pun boleh bertanya, sampai kapankah pandemi covid-19 ini berlangsung? 
Sebagai seorang dosen pada Program Studi Ilmu Komunikasi, Fakultas Ilmu-Ilmu Sosial, Universitas Nusa Nipa Indonesia, saya berpendapat bahwa situasi ketidakpastian yang terjadi akibat pandemi covid-19 ini dapat dicermati dari perspektif ilmu komunikasi. Mulai dari komunikasi kesehatan atau komunikasi terapeutik, teori pengurangan ketidakpastian, teori jarak atau prosemik hingga teori komunikasi massa dapat menjadi acuan untuk memberikan jawaban atas kondisi ketidakpastian akibat pandemi covid19. Tentu saja paradigma berpikir dalam ilmu komunikasi kiranya dapat mengurai benang kusut pemikiran dan pendapat terkait agenda kebijakan pemerintah yang tidak sedikit berbenturan dengan pemikiran dan pendapat khalayak di hampir seluruh pelosok negeri ini.

Ada banyak ketidakpastian dalam situasi pandemi ini. Kondisi ekonomi yang tidak menentu akibat pembatasan sosial menimbulkan ketidakpastian. Ketidakpastian juga terjadi manakala adanya pasien positif covid-19 diumumkan pemerintah, entah bagaimana keadaan yang akan terjadi di masa depan.

Komunikasi kesehatan memiliki relasi yang kuat dengan usaha manusia untuk menjaga kesehatannya terutama di masa pandemi covid-19 ini. Protokol kesehatan yang diberlakukan dari pusat hingga ke daerah menjadi mekanisme utama untuk mengatasi situasi ketidakpastian akibat pandemi ini.

Teori Pengurangan Ketidakpastian ini dapat dipakai sebagai landasan ilmiah dalam mengontrol upaya yang dilakukan oleh pemerintah yang nota bene menggunakan berbagai sumber daya termasuk dana yang besar mengatasi covid-19. Enoh Tanjong (2009) dalam penelitiannya menyarankan bahwa tata kelola pemerintah harus dikontrol melalui berbagai cara termasuk oleh media massa agar publik dapat ikut mengontrol. 
Interaksi warga dengan menggunakan media massa dan juga media sosial dan perkembangan teknologi komunikasi mestinya memudahkan pelayanan kesehatan melalui informasi yang tepat. Namun pada faktanya ada banyak problem dan ketidakpastian yang dialami warga berhadapan dengan berbagai berita tidak benar bahkan perundungan (bullying) di berbagai akun media sosial. Masyarakat menjadi tambah panik dan situasi menjadi tidak menentu. Hadad (2009:3-4) menyatakan bahwa apa yang dilakukan oleh media massa harus dapat dipertanggungjawabkan kepada publik, karena basis media massa adalah kepercayaan (trust) publik.

\section{Daftar Pustaka}

Pengalaman Empiris:

Pengalaman penulis sebagai penyintas covid-19.

Makalah Seminar:

Hadad, Toriq. 2009. "Hegemoni Media Massa: Bala atau Berkah?" (ms.) dalam Seminar Nasional bertajuk "Media Massa di Era Cyberspace", Yogayakarta.

Jurnal:

Tanjong, Enoh. 2009. Media Fight Against Corruption in Cameroon: Public Assesment. International Journal of Communication.Volume: 19. Issue: 2 Publication date: July- December 2009. Bahri Publications. 


\title{
BERINVESTASI SYARIAH DI ERA PANDEMI , MUNGKINKAH?
}

\author{
Molly Mustikasari, ME ${ }^{16}$ \\ (Universitas Muhammadiyah Bandung)
}

"pemilihan instrumen dan komposisi merupakan sebuah strategi dan upaya untuk tetap dapat berinvestasi dalam rangka menekan risiko serta memaksimalkan keuntungan"

Pandemi Corona Virus Desease 19 (Covid-19) dimulai dari Wuhan Cina yang merebak sekitar bulan September 2019 lalu. Diluar dugaan Indonesia menjadi salah satu negara yang terkena efek pandemi dengan dampak yang cukup signifikan terhadap kesehatan dan ekonomi. Tercatat pada laman covid19.go.id penduduk Indonesia terkonfirmasi covid sebanyak 3.967 .048 orang.

Sementara pertumbuhan ekonomi nasional Indonesia mengalami pertumbuhan negatif pada kuartal I tahun 2020, ini merupakan dampak dari kebijakan Pembatasan Sosial Berskala Besar (PSBB) pada April 2020 lalu, dalam upaya pemutusan sebaran Covid -19. Berefek domino pada kegiatan produksi dan distribusi yang terhambat juga terbatasnya aktifitas serta mobilitas masyarakat.

Efek pandemi Covid-19 juga berimbas pada dunia investasi dimana nilai Index Harga Saham Gabungan (IHSG) menunjukkan penurunan yang signifikan dan mencapai titik terendah di sepanjang tahun 2020 yaitu pada bulan Maret

16 Penulis adalah Dosen Universitas Muhammadiyah Bandung, pada Fakultas Ilmu Keislaman Prodi Ekonomi Syariah. Menyelesaikan program S2 pada Prodi Ekonomi Syariah di Universitas Islam Negeri Sunan Gunung Djati Bandung tahun 2016. 
2020 di titik 3.990 (economy.okezone.com, 2020). Pada awal bulan Juli tahun 2020 lalu , IHSG berada di level 4.905,39 namun pada bulan Juli 2021 IHSG berada di level 6.001,12 atau kenaikan hingga 22,34\%.

Dari data di atas, terdapat optimisme dalam berinvestasi hal ini tidak menyurutkan para investor untuk terus melakukan geliat investasinya dimasa pandemi walaupun tetap dalam tingkat perhitungan yang tinggi. Indikator positif lain, ditandai pula dengan peningkatan jumlah investor di Indonesia, pada pertengahan bulan Februari 2021 jumlah Single Investor Identification (SID) atau nomor identitias tunggal saham tercatat sebanyak 2 juta account yang pada akhir tahun 2020 hanya sebanyak 1,69 juta account. (investasi.kontan.co.id, 2021).

Melihat fenomena di atas maka dalam tulisan ini akan disampaikan bagaimana berinventasi dengan menggunakan instrumen investasi syariah di masa pandemi?

Investasi atau penanaman modal merupakan penempatan dana atau uang dengan harapan mendapatkan keuntungan di waktu yang akan datang. Bentuk Investasi yang kita ketahui terdiri dari dua hal yaitu : 1) Investasi pada sektor keuangan merupakan investasi yang tidak berwujud dimana nilai asetnya tidak berwujud . Contohnya investasi pada Reksadana Syariah, Surat Berharga Syariah Negara, dan lainlain, 2) Investasi pada sektor riil. Contoh yang bisa kita temui yaitu investasi berupa kendaraan, properti, mesin-mesin dan lain-lain.

Mengapa kita harus berinvestasi? Setiap orang memiliki cita-cita untuk dapat hidup serba berkecukupan, tidak mengalami kesulitan saat memenuhi kebutuhan hidupnya. Namun semua itu tidak dapat dilakukan dengan hanya berpasrah pada keadaan, tetapi diupayakan dengan sepenuh hati serta dalam koridor perencanaan yang terarah. Melalui investasi diharapkan keinginan-keinginan kita dapat terpenuhi sesuai rencana yang kita buat. 
Dengan mengetahui tujuan berinvestasi, dapat menjadi salah satu indikator untuk dapat menentukan jangka waktu investasi harapannya saat kita memerlukan dana maka kita dapat menikmati hasil investasi tersebut. Kata lain jangka waktu berinvestasi menentukan likuiditas dana yang kita butuhkan. Ada tiga aspek tujuan investasi berdasarkan jangka waktunya: a) jangka pendek (kurang dari 3 tahun) investasi untuk kebutuhan mendesak, b) jangka menengah ( 3 - 5 tahun) - contohnya investasi untuk memenuhi keperluan modal berbisnis, c) jangka panjang (di atas 5 tahun) - investasi untuk biaya pendidikan anak atau investasi masa tua (Suhartono dan Fadlillah Qudsi, 2008).

Pelaku investasi tidak terbatas pada gender dan usia, artinya sejauh memiliki dana untuk diinvestasikan ( merupakan excess fund setelah dikurangi cost for living, cost for saving dan cost for playing) serta memiliki pengetahuan yang mumpuni dalam berinvestasi maka seseorang bisa melakukan investasi. Mengapa harus didasari dengan literasi yang kuat tentang investasi? mengingat dalam berinvestasi ini mengandung risiko. Dalam investasi dikenal istilah high risk with high gain, semakin besar risiko semakin besar keuntungan yang diperoleh. Setiap investor harus memahami kejadian alamiah dalam berinvestasi tersebut tujuannya untuk menekan risiko yang akan terjadi.

Perintah berinvestasi dalam Islam terdapat dalam AlQuran surat Yusuf ayat 46-49. Bunyi terjemahan ayat 47:

“... Agar kamu bercocok tanam tujuh tahun (berturutturut) sebagaimana biasa; kemudian apa yang kamu tuai hendaklah kamu biarkan di tangkainya kecuali sedikit untuk kamu makan"

Adapun terjemahan ayat 48:

"Kemudian setelah itu akan datang tujuh (tahun) yang sangat sulit, yang menghabiskan apa yang kamu simpan 
untuk menghadapinya (tahun sulit), kecuali sedikit dari apa (bibit gandum) yang kamu simpan".

Ayat pada surat Yusuf di atas memberikan petunjuk kepada kita untuk tidak mengkonsumsi semua kekayaan yang kita miliki pada saat kita telah mendapatkannya, tetapi seyogyanya sebagian kekayaaan yang kita dapatkan itu kita tunda pemanfaatannya untuk keperluan yang lebih penting. Pengalihan pemanfaatan ini tujuannya untuk dikelola dan dikembangkan dalam upaya mempersiapkan masa depan termasuk di dalamnya biaya pendidikan dan masa pensiun.

Tentang penggunaan modal agar digunakan secara produktif Khalifah Umar Bin Khatab pernah memerintahkan kaum Muslimin untuk memanfaatkan modalnya secara produktif, beliau berkata :

"Siapa saja yang memiliki uang hendaklah ia menginvestasikannya dan siapa saja yang memiliki tanah hendaklah ia menanaminya".

Investasi di dalam Islam tidak semata mengejar profit duniawi namun untuk mendapat profit akhirat juga. Mengingat prinsip-prinsipnya sesuai dengan syariat Islam. Ada dua prinsip utama dalam berinvestasi dalam Islam yaitu halal dan maslahah (mendatangkan kebaikan). Selain itu ada prinsip-prinsip lain yang dilarang saat berinvestasi syariah, yakni bahwa investasi ini tidak mengandung maysir (spekulasi), gharar (ketidakjelasan) riba, ihktikar (menimbum), dan risywah (menyuap). Berinvestasi bukan melakukan peruntungan tetapi mendapatkan keuntungan dengan perhitungan yang akurat mempertimbangkan dan menganalisa kerugian dan keuntungan yang akan diraih. Gharar dalam sebuah transaksi bisa terjadi karena kekurangan informasi dan objek yang tidak nyata. Menurut Rodoni, A dan Fathoni M.A (2019) perbedaan gharar dan risiko yakni gharar adalah melakukan sesuatu tanpa memikirkan akibat yang ditimbulkan, sementara itu risiko 
adalah kemungkinan yang timbul akibat ketidakpastian yang diluar kontrol manusia.

Jenis instrumen investasi syariah berupa : Saham syariah ( surat berharga bukti pernyertaan modal kepada perusahaan), Sukuk (sertifikat yang mencerminkan bukti kepemilikan atas aset rill ) dan Reksa Dana Syariah (wadah untuk menghimpun dana masyarakat dikelola oleh Manajer investasi dalam bentuk portofolio efek) , instrumen investasi tersebut terdapat pada Pasar Modal syariah .

Berkaitan dengan investasi di masa pandemi, Work From Home (WFH) menjadi salah satu jalan untuk melakukan personal improvement. Mengingat WFH membuat orang harus tinggal di rumah dan memiliki banyak waktu yang bisa dimanfaatkan .

Personal improvement di bidang investasi bisa dilakukan dengan banyak cara : 1) Membaca buku-buku mengenai investasi , 2) Belajar melalui media sosial secara mandiri misalnya melalui kanal youtube, 3) Mengikuti training virtual melalui kelas webinar secara rutin, 4) Praktek langsung dengan membuat akun dan lakukan transaksi dengan modal paling minimal, 5) Meminta bantuan manajer investasi untuk mengelola aset kita.

Sementara strategi berinvestasi syariah bagi para investor yang sudah terjun di dunia investasi sebelum pandemi terjadi ada berbagai macam jurus. Salah satunya dengan melakukan diversifikasi portofolio investasi, yaitu melakukan investasi tidak hanya dalam satu instrumen investasi melainkan menggunakan berbagai macam instrumen investasi. Tujuannya disamping untuk menyelamatkan aset-aset kita juga untuk memaksimalkan perolehan keuntungan.

Strategi diversifikasi memiliki hubungan dengan tingkat risiko instrumen investasi dan risk profile investor. Setiap instrumen investasi memiliki tingkat risiko yang berbeda, adapun tingkat risiko investasi dibagi kedalam tiga kategori : a) konservatif, memiliki risiko paling rendah dengan return 
2\% per bulan, jenis instrumen investasi antara lain Deposito Syariah, Reksa Dana Syariah dan Sukuk, b) moderat, memiliki risiko sedang dengan return $2-5 \%$ per bulan, jenis instrumen investasi diantaranya berupa Reksa Dana Syariah Campuran, Properti dan Emas, c) agresif, memiliki risiko tinggi dan return $>5 \%$ per bulan, jenis instrumen investasinya berupa Reksa Dana Syariah Saham dan Saham. Sementara kategori risk profile investor terbagi dalam tiga bagian. Kategori pertama adalah risk taker (menyukai risiko), kedua risk averter (kurang suka risiko), ketiga risk indifferent (hati-hati terhadap risiko) (Prasetyo, 2017).

Berikut ini contoh diversifikasi instrumen investasi beserta besaran komposisi disesuaikan dengan risk profile investor dan risk level (bukan sebuah benchmark): 1) risk averter - konservatif: $50 \%$ sukuk, $30 \%$ pasar uang syariah, $20 \%$ saham syariah, 2) risk Indifferent-moderat: $40 \%$ saham, $40 \%$ sukuk, $20 \%$ pasar uang syariah, 3) risk taker- agresif: $50 \%$ saham, $30 \%$ sukuk , $20 \%$ pasar uang syariah.

Perencanaan keuangan merupakan financial roadmap seseorang dalam memenuhi kebutuhan hidupnya di masa yang akan datang dapat direalisasikan salah satunya melalui investasi. Pepatah bijak mengatakan Man proposes and God disposes, kita hanya sekedar merencanakan dan Allah yang menentukan..... 


\section{Daftar Pustaka}

https://economy.okezone.com/read/2020/12/30/278/233

6421/titik-terendah-ihsg-sepanjang-2020-pada-23maret-jatuh-4-9

https://covid19.go.id/peta-sebaran-covid19, diakses tanggal $21 / 8 / 2021$

https://investasi.kontan.co.id/news/ini-faktor-di-balikfenomena-tumbuhnya-investor-pasar-modal-global, diakses tanggal 21/8/2021

Prasetyo, Yoyok. (2017). Hukum Investasi \& Pasar Modal Syariah. Bandung: CV. Mitra Syariah Indonesia (MINA).

Rodoni, Ahmad dan Fathoni, M. A. (2019). Manajemen Investasi Syariah. Jakarta: Salemba Diniyah.

Suhartono dan Qudsi, Fadlillah. (2008). Portofolio Investasi \& Bursa Efek. Yogyakarta: Sekolah Tinggi Ilmu Manajemen YPKN. 


\title{
PENGAJIAN AL QUR'AN DI DAERAH PEDALAMAN ACEH SELAMA PANDEMI
}

\author{
Sufian Suri, Lc., MA ${ }^{17}$ \\ (IAIN Lhokseumawe)
}

"Meskipun dalam masa pandemi, aktivitas pembelajaran AlQur'an tetap dijalankan untuk menyelamatkan generasi muda berakhlak mulia di masa akan datang"

W asa pandemi Covid - 19 ini adalah masa masa sulit bagi berada pada golongan menengah ke bawah, bahkan juga mereka yang berada pada level menengah keatas. Kenyataan yang harus diterima pada masa pandemi ini tidak terlepas dari kehendak sang Maha Pencipta atas segala sesuatu. Bila Dia berkehendak maka tidak ada yang bisa mencegah dan tidak ada yang mustahil bagiNya.

Pandemi Covid 19 sudah memasuki tahun ke - 3 dan kasus covid yang terus bertambah menimbulkan pengaruh yang sangat signifikan terhadap perubahan tatanan hidup masyarakat, regulasi pemerintahan termasuk juga perubahan dalam sistem pembelajaran dan pendidikan, termasuk dalam

17 Penulis lahir di Aceh Utara, 25 Agustus, penulis merupakan Dosen IAIN lhokseumawe, bidang program studi Ilmu Al-Quran dan Tafsir, penulis menyelesaikan gelar Sarjana Strata Satu di Universitas Al-Azhar Cairo Mesir (2007), sedangkan gelar Magister diselesaikan di universitas Omdurman Islamic University Khartoum Sudan (2013). Dan sekarang sedang menempuh pendidikan Philosophy of Doctor di Universitas yang sama. Penulis juga aktif dalam kegiatan masyarakat pedalaman, khususnya pada kegiatan pengajian Al-quran dan ilmu-ilmu keagamaan. 
pembelajaran Al-Qur'an. Sesuai aturan pemerintah masyarakat harus menjaga jaga jarak dan tetap menjalankan protokol kesehatan dalam menjalankan aktivitas. Dengan segala keterbatasan dalam menjalankan aktivitas maka upaya untuk menghidupkan Al-Qur'an sejatinya tetap harus dijalankan. Al-Qur'an wajib ditadaburri.

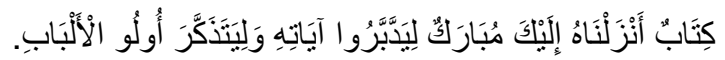

Artinya: "Ini adalah sebuah kitab yang Kami turunkan kepadamu penuh dengan berkah supaya mereka memperhatikan ayat-ayatnya dan supaya orang-orang yang mempunyai fikiran mendapat pelajaran." (QS Shaad [38]: 29).

Pengajian merupakan salah satu institusi yang cukup lama hadir sebagai lembaga yang memberi pendidikan kepada masyarakat. Dalam sejarah perjalanan perkembangan Islam, pengajian memberi peran yang besar dalam menyampaikan berbagai pengetahuan khususnya pengetahuan agama dan sosial (Alfisyah, dkk 2013).

Apapun kondisi diharapkan pengajian Al-Qur'an tidak boleh jeda apalagi berhenti diberikan pada anak dalam situasi dan kondisi apapun, termasuk era pandemi covid-19 yang mewabah di dunia. Pengajian Al-Qur'an era covid-19 dilaksanakan dengan berbagai cara oleh pendidik di masingmasing daerah termasuk di daerah tertinggal. Setiap daerah memiliki sistem pembelajaran sesuai kebutuhan masyarakat setempat.

Nanggroe Aceh Darussalam, merupakan salah satu provinsi di Indonesia yang diberi status sebagai daerah istimewa dan juga diberi kewenangan otonomi khusus, disini dipercaya sebagai tempat pertama tumbuh kembangnya Islam di nusantara yang kemudian menyebar luas ke daerah lainnya hingga negara asia tenggara, Aceh sebagai daerah yang bersyariat islam memiliki banyak tradisi adat dan istiadat yang bernuansa islami, salah satunya "Tradisi Pengajian" Al-quran, di tengah masyarakat. Bila kita melihat 
keutamaan dan usaha ikhtiar dalam menanamkan tradisi pengajian Al-Quran di masyarakat pedalaman atau di kampung, berarti kita sedang berusaha merawat tradisi yang ada di tengah masyarakat, yang kerapkali punah dan tidak terdokumentasikan. Kalaupun lestari, seringkali orang ataupun masyarakat sebagai pewarisnya tidak megetahui secara utuh nilai-nilai historis dan makna yang terkandung didalamnya. Tradisi yang tumbuh kembang di tengah masyarakat adalah karya cipta yang turun menurun, diyakini, dipahami dan dipraktikkan dalam kehidupannya. Masyarakat yang memiliki budaya adalah masyarakat yang mendiami suatu wilayah dalam jangka waktu yang lama (Didi Darmadi, 2016) .

Dalam tradisi pengajian yang sering dilakukan di tengah masyarakat tidak pernah terlepas dari peran seorang guru atau pengajar, namun setiap guru mempunyai metode dalam mengajar yang berbeda antara satu dengan yang lainnya, dengan melihat sisi kemampuan dari murid-muridnya. Hasan Langgulung mendefinisikan metode adalah cara atau jalan yang dilalui untuk mencapai tujuan pendidikan (Fahrul Razi Salim, dkk. 2017).

Proses belajar mengajar pengajian khususnya Al-quran, sangat berpengaruh pada rencana dan strategi yang baik dan tepat sehingga tujuan pembelajaran yang diinginkan dapat tercapai dengan mudah. Dengan demikian, penyusunan langkah-langkah pembelajaran, pemanfaatan berbagai fasilitas dan sumber belajar semuanya diarahkan dalam upaya pencapaian tujuan. Dalam menyusun strategi, perlu ditentukan tujuan yang jelas dapat diukur keberhasilannya, karena tujuan adalah roh nya dalam implementasi suatu strategi" (Sanjaya, 2006:126).

Berikut ini beberapa metode yang dipakai oleh para pengajar Al-quran di masyarakat pedalaman.

1. Metode Talaqqi (tatap muka) bermula dari metode penerimaan wahyu kepada nabi Muhammad SAW yang 
disampaikan oleh Jibril AS. ayat demi ayat dibacakan dengan tartil kemudian Rasul mengikutinya sebagaimana bacaan yang disampaikan Jibril. Metode ini yang banyak digunakan untuk hari ini oleh pengajar ngaji dalam mempelajari bacaan Al-quran, menggunakan metode Talaqqi, yaitu belajar bacaan Al-Quran dengan dicontohkan oleh guru ngaji kemudian mengikuti dan membacakan Al-Quran didepannya untuk kemudian diawasi dan dikoreksi.

2. Metode Sima'i (mendengarkan/menyimak). Metode Sima'i ini adalah metode yang sangat penting, karena seorang guru mendengarkan langsung bacaan yang dibacakan oleh murid sehingga jika ada kesalahan yang terdapat dalam bacaan murid baik itu makhraj huruf, waqf, madd, dan lainnya, didengarkan oleh guru bacaan tersebut setelah itu memberikan contoh bacaan yang benar secara langsung kepada murid dan menyuruhnya untuk membacakan kembali (Anang bustami, 2018).

Pengalaman yang dirasakan oleh para pengajar atau guru ngaji, bahwa menyimak bacaan murid secara langsung secara tatap muka, adalah hal yang sangat menarik dan mudah di peraktekkan, para guru bisa mendengarkan langsung bacaan dari murid dan jika bacaannya salah, maka harus diulangi dengan disertai memberikan contoh yang benar, ketika bacaannya masih salah, maka akan terus diulang-ulang sampai mereka benar bisa membaca dan paham bagaimana cara membacanya. Para guru juga menguji bacaan muridnya dengan bacaan (qiraah) yang sudah diajarkan dihari-hari sebelumnya, ini bertujuan untuk menguji seberapa paham para murid dalam mengingat dan mengenal bacaan-bacaan (qiraah) yang sudah pernah dipelajari sebelumnya. Jika terdapat kesalahan langsung dibenarkan bacaan dari muridnya, lalu memberikan contoh bacaan yang benar setelah itu murid langsung diberi pelajaran baru untuk menambah kepahaman murid dalam membaca setiap huruf bahkan ayat Al- Quran. 
Tradisi Pengajian Al-quran Masyarakat pedalaman Aceh ini dilakukan secara luring atau tatap muka, sekalipun tradisi ini dilakukan ditengah masa pandemi, namun proses pengajian ini masih terus dilakukan secara langsung, dengan menggunakan dua cara atau metode, yaitu Talaqqi dan Sima'i, dan sejauh pantauan yang dilakukan menunjukkan bahwa tradisi ini masih berjalan dan bertahan ditengah masyarakat pedalaman Aceh khususnya, sekalipun sudah ada intruksi protokol kesehatan dari dinas-dinas terkait, bukan berarti mereka tidak mematuhi prokes tersebut, tetapi inilah tradisi yang sudah melekat pada setiap guru ngaji dan juga peserta didik di masyarakat pedalaman, juga disebabkan dengan minimalnya sarana dan prasarana yang memadai untuk proses belajar secara daring, bahkan SDM (sumber daya manusia) dari diri pengajar sendiri belum mampu untuk beradaptasi dengan kebiasaan baru dengan penggunaan sarana teknologi.

Proses pengajian Al-quran pada masyarakat pedalaman yang belajar mengaji di masa pandemi ini menunjukkan bahwa, meskipun masa pandemi yang menuntut untuk tidak bertatap muka dan menjaga jarak, namun keadaan ini belum bisa diterapkan pada tradisi pengajian $\mathrm{Al}$-quran masyarakat pedalaman Aceh, sarana, prasarana, dan teknologi yang memadai, ditambah dengan bimbingan teknik kepada para guru ngaji juga kesiapan mental para akademisi, juga perhatian para pemerintah sangat diperlukan untuk persiapan generasi yang lebih baik dan unggul. Meskipun dalam masa pandemic aktivitas pembelajaran Al-Qur'an tetap dijalankan untuk menyelamatkan generasi muda berakhlak mulia di masa akan datang. 


\section{Daftar Pustaka}

Anang Bustami \& Didi Darmadi., (2018). Kiprah Guru Ngaji Perempuan Kampung Pada Orang Melayu Di Pulau Borneo. RAHEEMA: 5(1), 45-46.

Fadhilah, G. A. (2020). Peran Lingkungan Belajar dalam Menyikapi Pembelajaran Daring di Era Covid-19. Jurnal Ilmiah Fakultas Keguruan Dan Ilmu Pendidikan, 6(2), 106-116. https:// doi.org/10.35569

Manan Abdul. 2017. Teungku Inoeng. Banda Aceh: Lembaga Naskah Aceh.

Siregar, M. Y., \& Akbar, S. A. (2020). Strategi guru dalam meningkatkan kualitas mengajar selama masa Pandemi COVID-19. At-Tarbawi, 12(2), 180-188.

Hasanah Uswatun., (2020). Strategi dan Manajemen Dakwah Masa Pandemi Covid-19 Masyarakat Madura. IMEJ: $3(1), 50$.

Zhu, X., \& Liu, J. (2020). Education in and after Covid-19: Immediate responses and long-term visions. Postdigital Science and Education, 2(3), 695-699. 


\title{
QONA'AH SEBAGAI KUNCI KEBAHAGIAAN HIDUP SELAMA PANDEMI COVID-19
}

\author{
Cintami Farmawati, M.Psi., Psikolog 18 \\ (IAIN Pekalongan)
}

\begin{abstract}
"Dengan mengamalkan ajaran qana'ah dapat memengaruhi pola berpikir seseorang ketika menghadapi suatu permasalahan, baik kegagalan maupun kesenangan yang telah diberikan Allah SWT"
\end{abstract}

Coronavirus Disease 2019 (COVID-19) ialah suatu penyakit infeksi saluran pernapasan yang disebabkan oleh SARS$\mathrm{CoV}-2$ (severe acute respiratory syndrome coronavirus 2) atau Virus Corona. Pada awal ditemukannya COVID-19 bermula adanya kasus pneumonia yang problematis di Wuhan, China, dilaporkan pertama kali oleh World Health Organization (WHO) pada tanggal 31 Desember 2019. Penularan COVID19 ditengarai mengenai penjualan daging berasal dari penangkaran hewan liar di pasar makanan laut (Cui, et al., 2019:181). Gejala yang umum dialami pasien COVID-19 yaitu batuk, demam dan kelelahan (mialgia). Gejala yang lebih spesifik seperti batuk disertai dahak, batuk yang mengandung darah (hemoptisis), diare dan sakit kepala. Sedangkan gejala komplikasi seperti cedera jantung akut, infeksi bakteri sekunder, dan sindrom gangguan pernapasan akut.

18 Penulis lahir di Pemalang, 15 Agustus 1986, penulis merupakan Dosen IAIN Pekalongan dalam bidang Psikologi, penulis menyelesaikan gelar Sarjana Psikologi di Universitas Diponegoro Semarang (2009), sedangkan gelar Magister Profesi Psikologi diselesaikan di Universita Katolik Soegijapranata Semarang (2016). Gelar Sebutan Psikolog diperoleh dari Himpunan Psikologi Indonesia (2016). Contact person: 087711778089 \& email: cintamifarmawati@gmail.com 
COVID-19 ditetapkan menjadi pandemi global oleh WHO pada hari Rabu, tanggal 11 Maret 2020 (Pratiwi, dkk, 2020:4), keputusan tersebut karena kasus COVID-19 telah menginfeksi 121 ribu lebih manusia di Eropa, Asia, Amerika dan menyebar ke 118 negara. Setahun setelah penetapan tersebut, pandemi COVID-19 telah menginfeksi 118,5 juta lebih manusia dengan jumlah kematian sebesar 2.631.295 jiwa. Setelah satu tahun lebih pandemi COVID-19 telah mewabah dunia, belum ada satupun obat yang dapat menyembuhkan penyakit akibat COVID-19. Namun demikian, pasien COVID-19 jangan merasa pesimis, karena infeksi COVID-19 bisa disembuhkan. Menurut Debryna (dalam Imandiar, 2020) yang merupakan dokter dalam mengobati pasien COVID-19 di Rumah Sakit Darurat COVID-19 yang berada di Wisma Atlet Kemayoran menyebutkan bahwa seseorang yang memiliki pikiran positif dapat segera sembuh dari infeksi COVID-19. Pikiran positif dapat menghadirkan perasaan bahagia yang dapat mendorong adalanya peningkatan imun tubuh sehingga dapat melawan penyakit akibat COVID-19.

Sistem kekebalan tubuh merupakan hal yang penting dimasa pandemi COVID-19. Secara ilmu kedokteran, imunitas bisa didapatkan dari makanan dan nutrisi (Mustofa \& Suhartatik, 2020: 317-323). Sedangkan secara psikologis, imunitas yang tinggi didapatkan dari perasaan bahagia (Apriadji, 2007: 75). Perasaan yang dialami seseorang bisa berpengaruh terhadap sistem kekebalan tubuh. Sebagai contoh, stres dapat melemahkan sistem kekebalan tubuh dan rentan dengan penyakit. Sebaliknya, adanya perasaan bahagia bisa memperkuat kondisi tubuh (Mistar, 2021). Kondisi imun tubuh yang kuat sangat berperan penting untuk melawan infeksi virus terutama COVID-19.

Salah satu tanda kebahagiaan manusia adalah qana'ah. Qana'ah atau contentment menurut Nursi (Ali, 2014: 430445) sebagai suatu dimensi karakter individu yang sangat penting. Contentment dapat dihubungkan dengan konsep 
kepuasan dan kebahagiaan. Menurut Positive Psychology, bahwa ilmuwan sosial telah mempelajari berbagai kemungkinan yang berkontribusi bagi kehidupan yang lebih baik, yang dapat menyebabkan seseorang mengalami kenaikan mood yang positif dan kepuasan secara menyeluruh dengan kehidupan seseorang (Seligman and Csikszentmihalyi, 2000: 5-14). Contentment merupakan kondisi kepuasan emosional atau mental dari kemudahan menghadapi berbagai pikiran, situasi dan tubuh individu. Contentment memiliki makna bahwa individu dapat menerima berbagai situasi. Contentment adalah bentuk kebahagiaan yang lebih tentatif dan ringan.

Qana'ah telah dijadikan sebagai konstruk pengukuran yang menggunakan aspek merasa cukup, ikhtiar dengan menggunakan semua kemampuan yang dimiliki, dan berserah diri kepada ketentuan Allah (Ahya, 2019). Qana'ah sangat dibutuhkan dalam mencegah dan teguh dalam situasi sulit (resilien), seperti dalam meghadapi pandemi COVID-19 sehingga tidak menimbulkan adanya kecemasan yang berlebihan (Djalante et al., 2020). Farmawati, dkk (2020) menyebutkan bahwa untuk mencegah COVID-19 dengan memperkuat sistem kekebalan tubuh dengan self-healing secara fisik dan mental, qana'ah merupakan bagian dari selfhealing secara mental.

Pentingnya menguatkan Iman selama pandemi COVID-19 sebagai kunci kebahagian hidup dengan mempraktikkan sikap qana'ah pada kehidupan sehari-hari. Konsep qana'ah di dalamnya meliputi lima aspek mental, yaitu: (1) Ikhlas, bahwa apapun yang terjadi merupakan kehendak Allah SWT. Hal pertama yang harus diyakini, sesuai dengan firman Allah SWT: "Dan tiada sehelai daun pun yang gugur melainkan Dia mengetahuinya (pula), dan tidak jatuh sebutir biji pun dalam kegelapan bumi dan tidak sesuatu yang basah atau yang kering melainkan tertulis dalam kitab yang nyata (Lauh Mahfuzh)." (QS al-An'am: 59). Sebagai muslim, wajib ikhlas atas segala ketetapan dan kehendak Allah SWT, termasuk 
adanya Pandemi COVID-19., (2) Tawakal, seorang muslim sejati akan melihat setiap kejadian yang menimpa dirinya sebagai suatu kebaikan, selalu berusaha untuk mengambil hikmah dari setiap keadaan. Apabila ingin belajar dari setiap peristiwa, maka hikmah menjadikan ilmu kehidupan yang terbaik., (3) Sabar, yaitu sabar terhadap ketentuan Allah SWT dan akibat yang ditimbulkannya, seperti bekerja dari rumah, banyak sekali pekerjaan yang mungkin tertunda, kegiatan yang harus dijadwalkan kembali atau bahkan batal, pendapatan yang mungkin berkurang, pembelajaran secara online dan akibat lainnya. Sabar bukan hanya pasrah, namun juga ikhtiar. Meskipun aktivitas dibatasi terus berusaha untuk memberikan yang terbaik. Sabar juga berarti menjaga dan meningkatkan ibadah, baik ibadah wajib maupun ibadah yang sunah seperti membaca Al Qur'an, melaksanakan shalat sunah, membaca buku-buku Islam, diskusi mengenai agama dengan keluarga dan ibadah sunah lainnya., (4) Ikhtiar, bagi seorang muslim ikhtiar mutlak harus dilakukan. Ikhtiar meliputi dua, yaitu ikhtiar lahir, dan ikhtiar batin. Ikhtiar lahir merupakan upaya yang dilakukan melalui ikhtiar fisik, salah satu contoh ikhtiar lahir yang dilakukan masa pandemi COVID-19 adalah pemberian vaksin, pola hidup yang bersih dan sehat dengan menerapkan protokol kesehatan dan asupan gizi. Sedangkan ikhtiar batin terbagi menjadi dua, yaitu tawakkal dan berdoa., dan (5) Tidak Tertarik Tipu Daya Dunia, artinya melakukan segala kegiatan di dunia hanya untuk mendapatkan ridha dan kasih sayang dari Allah SWT, sehingga dimudahkan dalam menjalani kehidupan selama pandemi COVID-19.

Implementasi qana'ah selama pandemi COVID-19, memiliki beberapa fungsi, yaitu sebagai pengobatan, pencegahan dan pembinaan (Fabria, 2020: 227). (1) Qana'ah sebagai metode pengobatan adalah dengan mengetahui dan mengerjakan ajaran qana'ah yang bersumber dari pendekatan sufistik. Dengan mengamalkan ajaran qana'ah dapat memengaruhi pola berpikir seseorang ketika 
menghadapi suatu permasalahan, baik kegagalan maupun kesenangan yang telah diberikan Allah SWT. Semua peristiwa dalam hidup, jika dihadapi dengan adanya qana'ah maka dapat menjadi obat untuk segala penyakit kejiwaan. (2) Qana'ah sebagai pencegahan adalah sebagai kendali dalam menuruti segala ambisi, perasaan, dan motif-motif yang menuju kearah penyimpangan. Kondisi diri yang tidak dapat terkendali berdampak pada kesengsaraan, kepincangan, dan ketidakadilan bagi orang lain maupun diri sendiri. Individu yang tidak dapat mengendalikan diri, yaitu individu yang mengalami masalah kejiwaan seperti merasa menyesal, selalu gelisah, egois dan sebagainya. Sebaliknya, individu yang dapat mengendalikan dirinya merupakan orang yang memiliki kepuasan dan ketenangan jiwa. (3) Qana'ah sebagai fungsi pembinaan bahwa setiap individu yang memiliki sikap qana'ah akan bersikap syukur dan sabar. Semakin tinggi syukur dan sabar, maka semakin kuat motif agamanya, semakin tenang dan puas jiwanya, serta semakin dekat dan taat kepada Allah SWT. Orang yang memiliki sikap qana'ah akan memunculkan kekuatan batin yang tangguh dan kuat sehingga dapat memotivasi diri untuk menjadi lebih baik pada kondisi apapun terutama selama pandemi COVID-19.

Pentingnya qana'ah dalam kehidupan sehari-hari merupakan kata kunci yang patut dilakukan selama pandemi COVID-19. Selanjutnya ditambah dengan melaksanakan protokol kesehatan seperti memakai masker, mencuci tangan, menjaga jarak, mengurangi mobilitas, menghindari kerumunan dan memanjatkan do'a, rutin berolahraga, dan istirahat yang cukup serta mengonsumsi makanan empat sehat lima sempurna bisa menjadi obat sekaligus imunitas pada diri dalam menangkal COVID-19, sehingga tercipta kehidupan yang bahagia selama pandemi COVID-19.

\section{Daftar Pustaka}

Ali, M. F. 2014. Contentment (Qana'ah) and It's Role in Curbing Social and Environmental Problems. Jurnal Islam and Civilisational Renewa, 5(3): 430-445. 
Apriadji, W. H. 2007. Makan Enak utk Sehat, Bahagia, \& Awet $M d$. Jakarta: Gramedia Pustaka Utama.

Cui, J., Li, F., \& Shi, Z. L. 2019. Origin \& Evolution of Pathogenic Coronavirus. Nature Reviews Microbiology, 17(3): 181-192. Doi: 10.1038/s41579-018-0118-9.

Djalante, R., Lassa, J., Setiamarga, D., Sudjatma, A., Indrawan, M., Haryanto, B., Mahfud, C., Sinapoy, M. S., Djalante, S., Rafliana, I., Gunawan, L. A., Surtiari, G. A. K., \& Warsilah, H. (2020). Review and analysis of current responses to COVID-19 in Indonesia: Period of January to March 2020. Progress in Disaster Science, 6, 100091. https://doi.org/10.1016/j.pdisas.2020.100091

Farmawati, C., Ula, M., \& Qomariyah, Q. 2020. Prevention of COVID-19 by Strengthening Body's Immune System through $\quad$ Self-Healing. Populasi, 28(2), 70-81. DOI: https://doi.org/10.22146/jp.63430

Imandiar. 2020. COVID-19 Bisa Disembuhkan, Syaratnya Bahagia. Diakses pada https://health.detik.com/beritadetikhealth/d-5199329/covid-19-bisa-disembuhkansyaratnya-bahagia tanggal 2 Agustus 2021.

Mistar, H. 2021. Buang Jauh COVID-19, Bahagiakan Dirimu. Diakses pada https://www.mistar.id/edukasi/buangjauh-covid-19-bahagiakan-dirimu/ tanggal 2 Agustus 2021.

Mustofa, A., \& Suhartatik, N., 2020. Meningkatkan Imunitas Tubuh Dalam Menghadapi Pandemi Covid-19 di Karangtaruna Kedunggupit, Sidoharjo, Wonogiri, Jawa Tengah Selaparang. Jurnal Pengabdian Masyarakat Berkemajuan, 4(1): 317-323.

Pratiwi, R.R., Artha, D.A. and Nurlaily, H., 2020. Analisa Yuridis Penetapan Covid-19 Sebagai Kedaruratan Kesehatan Masyarakat Ditinjau Dari Peraturan Perundang-Undangan di Indonesia. Inicio Legis, 1(1): 114. 
Seligman, M. E. P., \& Csikszentmihalyi, M. 2000. Special issue: Positive psychology. American Psychologist, 55(1): 5-14. 


\title{
PANDEMI DALAM PERSPEKTIF TEOLOGI SUNNI
}

\author{
Cecep Taufikurrohman, MA., Ph.D ${ }^{19}$ \\ (Universitas Muhammadiyah Bandung)
}

\begin{abstract}
"Pandemi adalah ciptaan Allah, rahmat bagi orang beriman, adzab bagi yang kafir. Orang yang mati setelah kena pandemi, maka ia dapat pahala syahid. Dan pandemi merupakan ujian kesabaran"
\end{abstract}

$\mathrm{H}$ ampir dua tahun ini, dunia digemparkan dengan adanya pandemi Covid-19. Hal ini menyebabkan berubahnya system tata kehidupan dunia, baik dari sisi keyakinan maupun tradisi. Sebagai sebuah agama yang universal dan relevan dengan setiap kondisi zaman, ruang dan waktu, tentu saja Islam memiliki konsep dan pandangan khusus perihal pandemi. Islam memandang pandemi bukan hanya dari sisi kesehatan fisik atau ilmu kedokteran. Islam memandang pandemi sebagai sebuah fenomena yang erat kaitannya dengan dimensi teologis. Hal ini mengingat Islam merupakan agama yang tidak hanya memperhatikan fisik atau ruh/spiritual secara berat sebelah, tetapi memperhatikan keduanya secara seimbang.

Dalam perjalanan sejarahnya, umat Islam memiliki pengalaman yang sangat panjang dalam menghadapi

${ }^{19}$ Penulis adalah Dosen Fakultas Agama Islam (FAI) Universitas Muhammadiyah Bandung. Ia menyelesaikan program S-1 di Jurusan Aqidah dan Filsafat Islam Universitas Islam Negeri (UIN) Syarif Hidayatullah Jakarta pada tahun 2000. Gelar Master (S2) diraihnya di Jurusan Aqidah dan Filsafat, Fakultas Ushuluddin, Universitas Al-Azhar Mesir pada tahun 2009. Adapun Program S3 (Doktoral) diselesaikannya pada November 2020 di Jurusan Filsafat Islam, Fakultas Darul Ulum, Universitas Cairo, Mesir. Bidang keahliannya adalah Islamic Studies, terutama pada bidang: Teologi Islam, Filsafat Islam, Tasawuf dan Pemikiran Islam. Hp: 08953015-8527, e-mail: abdicecepgarut@yahoo.com, IG: buya_ct_rahman. 
pandemi, sebab bukan kali ini saja umat Islam menghadapi pandemi. Sejak zaman Rasulllah saw. masih hidup, kasus pandemi sudah terdengar oleh Rasulullah Saw. Saat itu, pandemi melanda Persia dan dikenal dengan Tha'un. Ia adalah penyakit berbahaya yang menular sangat cepat dan menyebabkan kematian dalam waktu singkat. (Ibn Hajar: tt). Ketika Siti 'Aisyah Ra bertanya kepada Rasulullah Saw. tentang Tha'un, beliau saw. menjelaskan:

"Sesungguhnya pandemi Tha'un adalah adzab yang Allah kirimkan kepada yang dikehendaki-Nya; dan Allah menjadikannya sebagai rahmat bagi mereka yang beriman. Tidaklah seorang hamba yang kampungnya terkena Tha'un, tapi ia bertahan di sana dengan sabar dan mengharap pahala Allah, dan pada saat yang sama ia sadar bahwa tak akan ada yang menimpanya selain telah digariskan-Nya, maka tidak ada balasan lain kecuali baginya pahala seperti pahala syahid." (HR. Bukhari).

Dalam sejarah Islam, pandemi yang paling banyak menelan korban adalah yang terjadi di Mesir, Syiria, Maroko, Irak dan Andalusia. Peristiwa ini didokumentasikan oleh para sejarawan yang mengalami langsung peristiwa tersebut seperti: al-Maqrizi, Ibn Tigri Bardi, Ibn Katsir, Ibn Iyas, Ibn Bathuthah, Ibn Adzari al-Marakisyi dan Ibn Hajar alAsqallani. (Ali al-Shalabi: 2015).

\section{A. Pembahasan}

\section{Pengertian Ahlusunnah Wal Jama'ah (Sunni)}

Secara sederhana, definisi Ahlusunnah adalah orangorang yang mengikuti sunnah (ajaran) Rasulullah Saw dan para sahabatnya secara konsisten, baik dalam urusan aqidah, amalan jasmaniyah (ibadah fisik) dan amalan/akhlak hati. (Syaikh Abi al-Fadhl: tt).

Di tengah tarik menarik klaim siapa yang paling layak disebut manivestasi kelompok Sunni, terdapat beberapa 
pendapat yang paling terbuka dan bernuansa ukhuwah, memahami adanya keragaman umat di bawah payung Sunni, antara lain yang dinukil oleh Imam Al-Zabidi dari Imam al-Subki:

"Ketahuilah, bahwa Ahlusunnah wal Jama'ah bersepakat pada satu keyakinan, meskipun cara dan metode untuk sampai pada keyakinan tersebut berbedabeda. Jika diteliti dengan menggunakan metode deduktif (istiqra), maka secara umum Madzhab Sunni terdiri dari tiga kelompok besar:

a. Ahl al-Hadits, dimana prinsip dasar ajaran mereka adalah al-Quran, Sunnah dan Ijma (al-Adillah alSam'iyyah).

b. Ahl al-Nadzar al-Aqli wa al-Shina'ah al-Fikriyyah (Ahli logika dan Pemikiran). Mereka terdiri dari Asy'ariyyah dan Hanafiyyah. Mereka bersepakat pada:

- Prinsip-prinsip argument rasional (al-Mabadi al'Aqliyyah) pada segala perkara yang penjelasannya tidak ditemukan dalam wahyu (al-Sam'u)

- Prinsip-prinsip ajaran wahyu (al-Sam'u) hanya pada hal yang menurut akal boleh

- Dasar akal dan wahyu dalam hal selain pada masalah tersebut.

c. Ahl al Wijdan wa al-Kasyf (Mereka yang focus pada ajaran hati dan rahasia ilahi). Mereka adalah para sufi. Prinsip metode ajaran mereka, pada tahapan awal sama seperti kelompok satu dan dua (Ahl alHadits dan ahl al-Nadzar) dan pada derajat berikutnya lebih banyak pada kasf (ketersingkapan pada rahasia-rahasia gaib serta ilham." (Azzabidi: 1994). 
Bahkan, Ibn Taimiyyah menyebutkan: setiap muslim yang bukan Syi'ah Rafidhah dapat mengklaim sebagai Ahlusunnah wal Jama'ah. (Ibn Taymiyah: 2/601).

Dengan demikian, jelaslah bahwa pengertian Madzhab Sunni sangat luas, tidak sesempit yang dimaknai oleh sebagian orang saat ini mengklaim diri paling Sunni.

\section{Beberapa Prinsip Keyakinan Dasar Teologi Sunni dan Kaitannya dengan Pandemi}

Dalam hal keyakinan, terdapat beberapa prinsip teologis yang dianut Madzhab Sunni. Dari sebagian prinsip keyakinan tersebut, terdapat beberapa keyakinan yang relevan dengan persoalan pandemi. Di antara keyakinan Sunni yang relevan dengan persoalan pandemi adalah:

\section{a. Asas Keesaan Sang Pencipta (Tauhid)}

Prinsip utama aqidah Islamiyyah adalah tauhi, yaitu keimanan bahwa Allah Swt adalah satusatunya pencipta (al-Khaliq), dimana tidak ada satu pun di alam raya ini yang dapat mencipta selain Allah Swt.

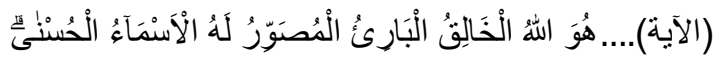

"Dia adalah Allah, Sang Pencipta, Sang Pengada, Sang Pembentuk Rupa, Sang Pemilik nama-nama indah...". (QS. Al-Hasyr: 24).

Karena itu, bagi Sunni, hanya Allah Swt. yang menciptakan segala sesuatu di alam raya ini, baik secara langsung ataupun tidak. Dengan demikian, pandemi adalah salah satu ciptaan Allah Swt. Keyakinan seperti ini banyak ditegaskan di dalam al-Quran, bahwa tidak ada satu musibah pun yang menimpa kita, kecuali Allah lah yang telah menetapkannya: 


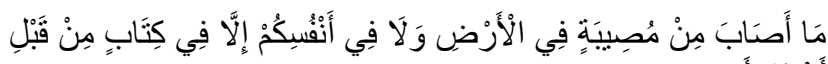

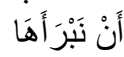

"Tiada suatu pun bencana yang menimpa di bumi dan (tidak pula) pada diri kalian, kecuali telah ditulis dalam kitab, sebelum Kami menciptakannya." (QS. Al-Hadid: 22).

\section{b. Hanya Kehendak Allah yang Menyebabkan Sesuatu Ada}

Secara ijma' (konsensus), Sunni mengimani bahwa apa saja yang Allah kehendaki, pasti akan ada. Sebaliknya, apa saja yang tidak Allah kehendaki, ia tidak akan ada. Karena itu Sunni mengatakan:

$$
\text { ما شاء الله كان وما لا يشاء لا يكو }
$$

"Apa saja yang Allah kehendaki, ia akan ada. Dan apa saja yang tidak Allah kehendaki, ia tidak akan ada). (Abdul Aziz: 2014).

Prinsip keimanan ini menegaskan, bahwa kehendak/iradah Allah Swt yang akan menjadikan sesuatu ada atau tidak ada. Oleh sebab itu, pandemi tidak akan terjadi tanpa kehendak Allah Swt.

\section{c. Alam Raya adalah Kerajaan Allah Swt}

Sunni mengimani bahwa alam raya merupakan kerajaan Allah Swt. Untuk itu, Allah memiliki kekuasaan untuk melakukan apapun di alam raya ini, sebab Dia adalah pencipta dan pemilik alam raya dan tidak ada yang dapat mempertanyakan perbuatan Allah Swt di alam raya ini, sebab semuanya milik Allah: 
"Allah tidak akan ditanyai tentang apa yang diperbuat-Nya, sedangkan manusia akan ditanyai." (QS. Al-Anbiya: 23).

Dengan demikian, Allah dapat melakukan apa saja yang dikehendaki-Nya dan kepada siapa saja, sebab tidak akan ada yang mempertanyakannya, termasuk perihal pandemi.

\section{d. Menyandarkan Segala yang Mumkin Kepada Allah Secara Langsung}

Bagi Sunni, tidak ada sesuatu pun yang dapat berpengaruh pada sesuatu lainnya, termasuk hukum sebab akibat, sebab bagi Sunni, segala sesuatu harus dikembalikan kepada Allah secara prinsip. (Izza al-Abidah, tt).

Berdasar empat prinsip teoligi Sunni di atas, Sunni memandang bahwa pandemi--yang merupakan salah satu fenomena di alam ciptaan Allah--tidak terlepas dari qudrah dan iradah Allah. Virus dan pandemi tidak akan pernah ada di alam raya ini jika bukan karena kehendak Allah.

Keyakinan Sunni tersebut dikuatkan oleh berbagai ayat dalam al-Quran (salah satunya surat Al-Baqarah: 155) serta berbagai hadits Rasulullah Saw. yang menegaskan bahwa segala sesuatu di alam raya ini hanya akan ada atas kehendak dan izin-Nya.

Rasulullah Saw. bersabda:

"Tidak ada penyakit menular (adwa)....." (HR. Bukhari)

Lalu seorang Arab pedalaman bertanya: "Wahai Rasulullah, lalu bagimana dengan unta yang ada di padang pasir, bersih laksana kijang. Lalu datang padanya unta berpenyakit, hingga unta sehat itu ikut tertular dan ikut sakit?" Nabi Saw. menjawab: "Lalu, siapakah yang menulari yang pertama?" (Shahih Bukhari, No. 5328). 
Maksudnya: jika benar bahwa unta sehat itu sakit karena didatangi unta sakit, maka siapakah yang menulari unta pertama yang sakit itu?" tentu jawabannya: Allah lah yang menciptakan penyakit pada unta yang paling pertama sakit.

Hadits ini menegaskan, bahwa virus atau pandemi tidak memiliki kekuatan apapun untuk berpindah atau menularkan kepada objek yang lain, yang membuat objek kedua tertular. Logika orang Badui (pedalaman Arab di atas), difahami bahwa penyebab sakitnya unta kedua adalah unta pertama yang sakit dan bercampur dengan unta sehat. Logika ini dibantah dengan logika iman: jika perkiraanmu benar bahwa penyebab sakitnya unta yang sehat adalah unta yang sakit, lalu siapa yang menulari unta pertama yang sakit? Maka tentu jawabannya, sakit tersebut berasal dari Allah Swt.

Terdapat beberapa hadits lain yang memerintahkan menghindar dari pandemi, yang secara substansi mendukung bahwa hanya atas izin Allah lah penyakit dapat menular.

\section{B. Kesimpulan}

Dari penjelasan di atas, teologi Sunni memandang pandemi sebagai berikut:

1. Pandemi adalah ciptaan Allah, sebab hanya Dia Sang Pencipta

2. Pandemi adalah adzab bagi yang kafir tapi rahmat bagi orang beriman

3. Orang yang mati setelah kena pandemi, maka ia dapat pahala syahid.

4. Pandemi adalah ujian kesabaran. 


\section{Daftar Pustaka}

Al-Quran al-Karim

Kitab Hadits Shahih Bukhari

Al-Shallabi, Muhammad Ali. 2005. Siratu Amir al-Mu'minin Umar ibn al-Khattab Ra: Shakhshiyatuhu wa Ashruhu, Cairo. Muassasah Iqra.

al-Zabidi, Muhammad bin Nuhammad al-Husaini. 1994. Ittifaf al-Sadah al-Muttaqin Bisyarh Ihya Ulumiddin, Mu'assasah al-Tarikh al-Arabi, Beirut.

Ibn Taymiyyah Taqiyuddin al-Harrani. 1997. Minhaj alSunnah, Darul Fikr, Bierut.

Ibn Hajar al-Asqallani, Badzl al-Maun fi Fadl al-Tha'un, Dar alAshimah, Riyadh: tt.

Saif al-Nashor, Abdul Aziz, Prof. Dr., al-Barahin al-Aqliyyah wa al-Naqliyyah ala-Al-Aqaid al-Imaniyyah, Maktabah alJamiah al-Azhariyyah, Cairo: 2014.

al-Abidah, Izza Ramadhan. al-Qudrah al-Ilahiyyah wa amil alAsbab, Muassasah Thaba, Dar al-Faqih, Cairo: tt. 


\title{
OPTIMALISASI FUNGSI MASJID DI MASA PANDEMI COVID-19
}

\author{
Takdir Alisyahbana, M.Pd.I ${ }^{20}$ \\ (STAI Bumi Silampari)
}

\begin{abstract}
"Tidaklah sekelompok orang berbaur di suatu masjid (rumah Allah) untuk membaca Al Qur'an, melainkan mereka akan diliputi ketenangan, rahmat, dan dikelilingi para malaikat, serta Allah akan menyebut-nyebut mereka pada malaikatmalaikat yang berada di sisi-Nya" (HR. Muslim)
\end{abstract}

Fenomena saat ini, masa pandemi COVID-19, di beberapa
tempat banyak terdapat bangunan masjid besar serta mewah beserta disain arsitektur terbaik dengan menara masjid yang tinggi disertai dengan suara gemuruh yang menyampaikan dzikir dan doa pujian melalui pengeras suara. Pengurus masjid, Ustadz dan kyai dalam majelis taklim terdengar melengking di siang hari melalui kantor-kantor yang sedang rapat memberikan tausiyahnya. Pemudapemuda saleh tampak berdiri di bawah terik matahari sambil menyodorkan kotak-kotak sedekah atau jaring penangkap untuk pembangunan rumah ibadah. Hanya saja yang terjadi meskipun masjid-masjid telah banyak, tak jarang dalam satu kampung berdiri dua sampai empat masjid tetapi hati jamaahnya kosong terlebih pada saat masa pandemi ini. Agama kita sepertinya hanya berakhir pada nilai-nilai ritual sehingga ibadah kita rusak akibat tidak mampu

${ }^{20}$ Penulis lahir di Maur Muratara, 12 November 1960, penulis merupakan Dosen STAI Bumi Silampari Lubuklinggau dalam bidang ilmu Pendidikan Islam, penulis menyelesaikan gelar Sarjana di UIN Maulana Hasanudin Serang, Banten (1990), sedangkan gelar Magister Pendidikan Islam diselesaikan di UIN Fatmawati Sukarno Bengkulu (2013). 
menunjukkannya dalam wujud rahmatan lil 'alamin (Tasmara 2009).

Sofyan Syafri Harahap mengatakan bahwa "masjid merupakan asas utama dan terpenting bagi terwujudnya masyarakat Islam, karena umat Islam tidak akan terwujud dengan kokoh dan rapi kecuali ada komitmen terhadap sistem, aqidah dan tatanan Islam yang sebenarnya. Hal ini tidak dapat ditumbuhkan kecuali dengan semangat masjid" (Harahap 1993). Setidaknya ada tiga fungsi utama masjid yang harus dipahami oleh pengelola masjid/pengurus masjid, yaitu fungsi masjid sebagai tempat beribadah, fungsi masjid dalam bidang sosial kemasyarakatan, dan fungsi masjid dalam bidang ekonomi.

\section{Masjid Tempat Kegiatan Beribadah}

Masjid secara umum adalah tempat dilakukannya kegiatan beribadah. Ibadah yang dialkukan berupa ibadah yang wajib maupun ibadah yang sunnah. Ibadah yang dilakukan juga adalah ibadah yang setiap hari rutin berupa shalat jamaah, maupun ibadah yang dilakukan pada hari jum'at atau shalat jum'at serta ibadah tahunan seperti pada bulan Ramadhan atau hari besar islam yang rutin terjadi. Tentu saja, dalam kondisi pandemi ini ini, ibadah yang dilakukan haruslah menyesuaikan dengan mengikuti protokol kesehatan (prokes) covid-19, antara lain dengan cara 5M; mencuci tangan, lalu memakai masker, kemudian menjaga jarak, selanjutnya menjauhi kerumunan, dan pada akhirnya mengurangi mobilitas atau melakukan kegiatan berpergian yang tidak penting.

Masjid sebagai tempat kegiatan beribadah dengan tujuan untuk meningkatkan ketakwaan dan keimanan kita kepada Alloh (Subhanahu Wa Ta'ala). Keimanan adalah sebuah hal mendasar bagi kita sebagai umat Islam. Iman merupakan "fondasi dalam menjalani hidup sebagai manusia seutuhnya. Iman pula yang menjadi pegangan hidup kita dalam memanusiakan diri kita. Dengan iman, kita melepaskan diri 
dari penghambaan kepada sesama makhluk, untuk memurnikan tauhiid kita hanya kepada Allah Subhanahu Wa Ta'ala.

Sebagaimana kita ketahui "iman" satu akar kata dengan aman, amanah, dan al-Amin, dapat kita tafsirkan bahwa iman akan melahirkan rasa aman pada diri kita. Kita tidak merasa takut dan khawatir akan kebangrutan dan kemiskinan karena dengan iman akan melahirkan rasa aman yang luar biasa, karena kita akan merasakan keakraban dengan Alloh (Subhanahu Wa Ta'ala). Rasa aman tersebut melahirkan kualitas moral, sense of responsibility, atau yang kita sebut dengan amanah. Dan bila seseorang sudah memiliki keyakinan dan kecintaan yang kuat (iman) dan merasa terjamin moralitasnya (aman), serta memiliki sense of responsibility (amanah), maka pantaslah dia menyandang gelar al-Amin (the most trusted people)" (Tasmara 2009).

\section{Masjid Tempat Kegiatan Kemasyarakatan Dan Sosial}

Setiap kita sebagai seorang muslim sangat menjunjung tinggi nilai-nilai moral. Karena akhlak adalah bekal kita untuk masuk surga. Oleh karena itu, kita semua sangat memahami bahwa beragama yang baik adalah bentuk akhlak yang baik. Kita juga memahami bahwa jika buruk akhlak mkana runtuhnya agama. Rusaknya citra agama karena pemeluknya sendiri yang memiliki akhlak yang buruk.

Rasulullah (sallallahu alayhi wa sallam) memiliki akhlak mulia yang harus diteladani oleh setiap muslim (lihat QS alQalam: 4 yang artinya "Sesungguhnya kamu adalah orangorang yang berbudi luhur, berakhlak mulia). Rasulullah (sallallahu alayhi wa sallam) diutus untuk menyempurnakan akhlak "innamaa bu'itstu li utammimal akhlaaq! Akhlak atau sifat, kepribadian (karakter, kepribadian) yang kemudian menjadi kosakata dalam bahasa Indonesia merupakan wujud jamak dari kata khuluq (tunggal, mufrad) yang erat kaitannya dengan kata khalq. (ciptaan). Dan Alloh (Subhanahu Wa Ta'ala) disebut Al-Khaliq (Sang Pencipta). Sedangkan hasil 
ciptaannya, atau segala sesuatu di luar dirinya disebut makhluk. Dengan demikian akhlak adalah sifat atau kepribadian seorang hamba (makhluk) yang mendambakan pertemuannya dengan kekasih yang telah menciptakannya (Al-Khaliq) dengan mengikuti petunjuk dan sifat yang diperintahkan oleh Sang Pencipta (Tasmara 2009).

Hanya saja saat ini di antara kita masih membutuhkan bimbingan dalam hal akhlak, baik melalui diri kita sendiri dengan niat yang benar-benar ingin menjadi baik dan lebih baik, melalui lingkungan yang ada, melalui kegiatan di masjid, melalui silaturrahmi dan hal lain yang ingin kita semua tingkatkan untuk memperbaiki akhlak kita.

\section{Masjid Pusat Kedermawanan (Pemberdayaan Ekonomi)}

Setelah masjid melatih akhlak, hal selanjutnya yang terjadi adalah akhlak akan membangkitkan kedermawanan atau jiwa social untuk berbagi. Hal ini dikarenakan Akhlak seorang muslim hakiki nya adalah akhlak yang sangat peduli terhadap sesama (humanisme). Seperti yang kita ketahui gambaran ketika pihak Ansar yang membantu pihak Muhajirin yang rela atas rumah dan hartanya untuk dibagi dengan penuh keikhlasan, karena terpanggil memiliki jiwa akhlak yang peduli dengan penderitaan sesama. Kaum Ansar dan Muhajirin adalah individu-individu yang memiliki semangat bahagia serta senang untuk memberi serta berbagi.

Memiliki sifat dermawan merupakan nilai kemanusiaan yang sangat tinggi, luar biasa dan terhormat. Tidak hanya dihadapan sesama manusia, tetapi juga dihadapan Alloh (Subhanahu Wa Ta'ala). Orang yang dermawan akan menjadi jamaah utama yang pelit, karena seorang dermawan, sekecil apapun perilaku ibadah ritualnya, bisa langsung dirasakan oleh manusia. Sedangkan jika ada sifat kikir atau pelit, betapapun melekat pada diri orang yang beribadah, rasanya pahit seperti empedu bagi orang lain.

Kedermawanan juga akan melahirkan sikap peduli. Jiwanya tersentuh melihat penderitaan orang lain. Seorang 
yang dermawan, memikul beban amanah untuk menyelamatkan harga dan martabat umat Islam dan umat manusia tanpa memandang ras seta agama dengan penuh rasa tanggung jawab. Salah satu kerinduannya di tengah kehidupan sosial tak lain adalah menjadikannya pelita yang bersinar yang menaburkan rahmatan lil 'alamin (Tasmara 2009).

\section{Masjid Tempat Pelayanan Masyarakat dengan Empati}

Masjid merupakan cerminan dari segala aktivitas umat, masjid merupakan tolak ukur dan ciri kesejahteraan umat di wilayah sekitar masjid. Namun jika tidak mampu menjadi pusat kehidupan masyarakat, tentu akan menjadi pertanda negatif munculnya disorientasi dalam kehidupan masyarakat. Dalam dua situasi ini, umat akan mengalami kebingungan dan menderita berbagai penyakit mental dan fisik dan tidak dapat menikmati distribusi aliran kesenangan dan energi dari Alloh (Subhanahu Wa Ta'ala) (Nana 2002).

Masjid juga harus menjadi tempat mengabdi ummat islam dengan cinta bukan hanya karena kewajiban semata. Namun, sesungguhnya merupakan keinginan yang besar bahwa masjid ada karena untuk melayani. Melayani atau membantu seseorang merupakan wujud kesadaran dan kepedulian terhadap nilai-nilai kemanusiaan. Memberikan pelayanan dan bantuan merupakan investasi yang akan menuai keuntungan. Bukan hanya di akhirat saja, tapi di dunia ini mereka sudah merasakannya.

\section{Melayani dengan Empati}

Toto Tasmara mengatakan bahwa empati adalah kemampuan seseorang untuk memahami orang lain. Merasakan rintihannya, mendengarkan detak jantung orang lain, sehingga mampu beradaptasi dengan merasakan kondisi batin orang lain. Empati sosial telah terpatri dalam jiwa besar Nabi Shallallahu 'alaihi wa sallam, sebagaimana firman Alloh (Subhanahu Wa Ta'ala) dalam QS at-taubah: 128, "Sesungguhnya telah datang kepadamu seorang rasul dari 
kaummu sendiri, penderitaan yang kamu alami itu berat, (dia) sangat menginginkan (iman dan keselamatan) untukmu, pemaaf dan penyayang bagi orang-orang yang beriman".

"Pemimpin yang empatik akan melahirkan solidaritas dan kemudian menyebarkannya ke dalam kesadaran kolektif, terutama di tengah situasi pandemi saat ini. Kepemimpinan adalah keteladanan dan sikap yang sangat memperhatikan orang-orang yang dipimpinnya (Tasmara 2009).

\section{Daftar Pustaka}

Harahap, Sofyan Syafri. 1993. Manajemen Masjid. Yogyakarta: PT. Dana Bhakti Wakaf.

Nana, Rukmana DW. 2002. Masjid Dan Dakwah, Merencanakan, Membangun Dan Mengelola Masjid, Mengemas Substansi Dakwah, Upaya Pemecahan Krisis Moral Dan Spritual. Jakarta: Almawardi Prima.

Tasmara, Toto. 2009. The Secret of Iman - Penyegar Semangat \& Penyejuk Iman. Jakarta: Gema Insani. 


\title{
MENINGKATKAN KWALITAS SUMBER DAYA MANUSIA GURU NGAJI PADA MASA PANDEMI COVID-
}

\section{9}

\author{
Rahmat Alamsyah, S.Ag., M.Ag. ${ }^{21}$ \\ (Universitas Muhammadiiyah Bandung)
}

"Kreatifitas para guru ngaji sangat dibutuhkan agar anakanak tetap bisa menikmati masa sekolah atau belajar sekalipun tidak tatap muka di ruang kelas"

Cejak dinyatakan sebagai pandemi oleh Direktur Jendral
Gorld Health Oraganization (WHO), Tedros Adhanom
Ghebreyesus per tanggal 11 maret 2020, Covid-19 telah
mempengaruhi sendi-sendi kehidupan masyarakat dunia.
Berbagai upaya dan kebijakan diberlakukan oleh setiap
negara untuk memutus penyebaran virus ini dari mulai
pencegahan, pengawasan sampai tindakan penyelamatan
medis. Salah satu kebijakan yang sangat berpengaruh adalah
adanya pembatasan aktivitas sosial baik yang bersifat
ekonomi, keagamaan, pedidikan dan lain sebagainya. Hal ini
menyebabkan pola kehidupan sosial manusia berubah dari
interaksi secara langsung bertatap muka menjadi ruang
virtual melalui berbagai media sosial dalam jaringan internet.

Dalam teori interaksi sosial, kebutuhan mendasar manusia adalah tatap muka dan berkomunikasi untuk memenuhi kebutuhan hidupnya. Jika dua unsur ini terhalang (blocked), dapat di pastikan masyarakat akan mengalami

21 Penulis adalah dosen unversitas Muhammadiyah Bandung pada fakultas Agama Islam Program Studi Komunikasi dan Penyiaran Islam. Saat ini sedang menempuh Pendidikan Strata tiga (S.3) di Universitas Islam Negeri Sunan Gunung Djati Bandung Program Studi Releigious Studies. 
kebingunan sosial (social confuse). Namun demikian kita masih tetap bersyukur virus ini muncul di era revolusi industri 4.0, dimana model interaksi sosial baru tengah terbentuk melalui supportive technology, karena sekalipun tatap muka terhalang manusia tetap masih bisa berkomunikasi dan kolaborasi lewat media social (Wiberg, 2004: 3-4).

Dalam hal pendidikan, proses belajar mengajar pun berubah dari kelas secara fisik menjadi dalam bentuk daring atau online. Pembelajaran daring ini memiliki tantangan tersendiri dimana siswa berada jauh dari jangkauan pengajar. Berdasarkan beberapa penelitian mengenai proses belajar mengajar di masa pandemi baik siswa maupun penagajar sama-sama merasakan kesulitan dan kebosanan. Hal ini di sebabkan oleh beberapa karakteristik belajar tatap muka dan online yang berbeda seperti kurang adanya ikatan emosional, kesulitan mengontrol fokus belajar, alur serta arah komunikasi yang terbatas dan lain sebagainya. Selain itu pilihan pada model aplikasi media juga berpengaruh, sebagai contoh sebagian besar pengajar menginginkan media zoom atau google meet, sedangkan siswa memilih media whats upp karena tidak menyedot banyak kuota (Sakkir, 2020: 3-4). Oleh karena itu pembelajaran daring tidak selamanya berhasil, selain faktor sumber daya manusia, metode dan gaya belajar juga tergantung pada lingkungan teknologinya (Qoriawati, 2021: 11). Belajar daring pada anak-anak lebih kompleks lagi karena terbatasnya pengetahuan mereka dan aspek stabilitas mood yang berubah-rubah sehingga perlu di damping oleh orang tua.

Salah satu proses belajar mengajar yang terdampak pandemi adalah pembelajaran agama seperti belajar ngaji quran dan dirasah islamiyah terutama untuk nak-anak. Di masa pandemi masjid, mushala, majlis-majlis ta'lim dan sekolah taman kanak-kanak (Raudhatul Athfaal) juga di batasi pengunaanya sehingga mereka harus belajar di rumah. Peran guru ngaji sangat besar dalam menanamkan niai-nilai 
kebajikan sejak usia dini, belajar baca Qur`an, belajar sholat, menghafal doa-doa, dan lain sebagainya. Dalam konteks inilah dibutuhkan kreatifitas para guru ngaji agar anak-anak tetap bisa menikmati masa sekolah atau belajar sekalipun tidak tatap muka di ruag kelas.

Pada dasarnya nilai-nilai kebajikan tersebut tidak hanya di butuhkan oleh anak-anak saja tetapi juga oleh orang dewasa bahkan orang tua, oleh karena itu pengajaran agama harus tetap ada bahkan dikuatkan agar masyarakat memiliki ketahanan fisik sekaligus mental dimasa pandemi ini. Namun demikian kendala dan hambatan dalam belajar mengajar masih ada terutama peralihan dari kelas secara fisik ke kelas virtual. Guru ngaji dituntut untuk tetap bisa memberikan pengajaran yang menarik, berkompetensi dan menjadi contoh keteladanan.

Paling tidak ada empat hal yang perlu disiapkan untuk beradaptasi dengan perpindahan pola belajar ruang kelas fisik ke ruang digital. Pertama; sumber daya manusia yang mencakup pengetahuan teknis pengoperasian model aplikasi ruang pembelajaran, kedua; pengemasan materi pembelajaran secara audio visual sesuai kebutuhan, ketiga; pola komunikasi interaktif dan ke empat; supporting system atau daya dukung lingkungan seperti jaringan internet dan ketersediaan kuota. jika melihat 4 hal di atas maka dapat di lihat bahwa 3 bagian pertama berkaitan dengan sumber daya manusia dan satu berkaitan dengan sumber daya teknologi. Oleh karena itu seorang pengajar baik pada sekolah formal maupun non formal harus melakukan peningkatan skill atau kompetensi untuk menjawab kebutuhan tersebut.

Beberapa kecakapan dan keterampilan yang harus di miliki seorang guru ngaji dimasa pandemi dinataranya adalah: pertama, kemampuan teknis digital yaitu mengoperasikan beberapa aplikasi ruang belajar dan media sosial pada layanan yang tersedia seperti zoom, google meet, goggle class dll. Setelah mengetahui cara pengoperasian mulailah melakakan uji coba agar dapat di evaluasi apa yang 
menjadi kendala pembelajaran. Kedua belajarlah strategi komunikasi pada ruang digital, meskipun secara umum proses komunikasi itu sama akan tetapi pada ruang digital harus lebih hati-hati karena pendengar tidak hanya siswa tapi boleh jadi ada orang lain disampingnya. Bahkan dalam beberapa ekspose tampilan kita di tuntut untuk lebih menjaga prilaku sehingga pembelajaran dirasa nyaman (Farhana, 2021: 317). Ketiga pelajari dan ikuti pelatihanpelatihan metode pembelajaran baca quran agar kita memiliki wawasan dan bahan materi ajar yang efektif sehingga dapat membantu siswa cepat bisa dan mengerti cara membaca Al-quran dengan benar sesuai kaidahnya. Ke empat membuat materi tersebut dalam bentuk blended learning, yaitu pembelajaran campuran antara tatap muka dengan e-learning atau pembelajaran digital yang memungkinkan siswa belajar secara mandiri namun tetap terkendali.

Menurut Hasibuan, proses pengembangan dan peningkatan Sumber daya terbagi menjadi dua; formal dan informal (Ningrum, 2009: 4). Peningkatan SDM secara formal dapat dilakukan melalui pelatihan dan pendidikan sesuai dengan kebutuhan kompetensi, ini biasa terjadi di perusahaan atau lembaga pendidikan sedangkan secara informal bergantung kepada kreatifitas dan semangat individu untuk mengakses segala macam informasi dan keterampilan teknis yang menunjang. Dalam hal ini guru ngaji dapat mengambil pilihan kedua. 


\section{Daftar Pustaka}

Farhana, Syarifah, Safitri, Agustini, Magdalena, Ina. 2021. Strategi Guru Dalam Meningkatkan Kwalitas Mengajar Di Masa Pandemi Covid-19. Cerdika: Jurnal Ilmiah Indonesia, Maret 2021, 1 (3), 313-320. H. 317. Doi: http://cerdika.publikasiindonesia.id/index.php/cerdik a/index.

Ningrum, Epon. 2009. Pegembangan SDM di Bidang Manusia Pendidikan. Jurnal Geografi Gea. Vol. 9. No.1. hal. 4. Doi: http// Doi.org. /10.17509/ gea. V9ii.1681.91133.

Qoriawati, Uhlul, Maknun, Lu'luil. 2021. Upaya Peningkatan Kualitas Pembelajaran Daring bagi Peserta Didik MI/SD pada Masa Pandemi Covid-19. Jemari: Jurnal Edukasi Madrasah Ibtidaiyah, Vol. 3 No. 1, h. 11. Doi: https://doi.org/10.30599/jemari.v3i1.769.

Sakkir, Gerninastiti, Dolkah, Syaripuddin, Ahmad, Jamaluddin. 2020. Favorite E-Learning Media in Pandemi Covid-19 Era. Jurnal Studi Guru dan Pembelajaran. No.3. Vol.3. hal. 483. Doi: https//. ejournal. my.id.

Wiberg, Mikael. 2004. The Interaction Society: Practice, Theories and Supportives Technologies. USA: Information Science Publishing. 


\section{BAB III}

\section{PERANAN PENDIDIK DAN ORANG TUA SAAT}

PANDEMI

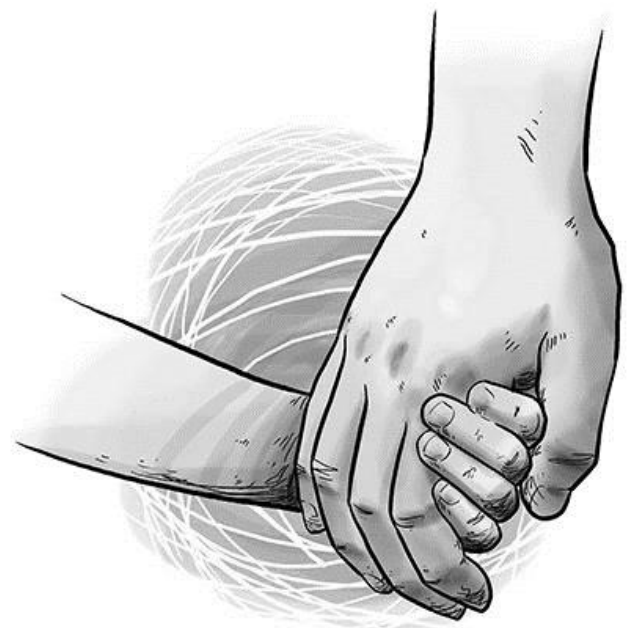




\title{
MENJADI PENGAJAR HEBAT DI TENGAH COVID-19
}

\author{
Dr. Sholihatul Hamidah Daulay, S.Ag., M.Hum ${ }^{22}$ \\ (Universitas Islam Negeri Sumatera Utara)
}

"Dengan berjalannya waktu, diharapkan guru mampu melakukan pembelajaran online secara efektif sehingga karakteristik guru hebat di masa pandemi ini dapat terwujud"

$\mathrm{D}^{\mathrm{i}}$ i masa Covid-19 ini, dunia mengalami banyak perubahan baik itu dari segi interaksi sosial di masyarakat maupun dalam bernegara. Penanganan yang rumit terhadap wabah ini mengakibatkan para pemimpin dunia terpaksa melakukan social distancing guna memutus penyebaran Covid-19, kebijakan ini sangat berakibat fatal bagi kehidupan manusia secara komprehensif pula. Di satu sisi, bidang pendidikan juga terkena dampaknya yakni dengan adanya keputusan Pemerintah yang memindahkan proses pembelajaran yang awalnya dari sekolah/madrasah menjadi di rumah, sehingga guru dan siswanya terpaksa beradaptasi dan mengikuti pembelajaran daring dengan memanfaatkan penggunaan teknologi.

Satu setengah tahun terakhir ini adalah masa yang sangat sulit bagi dunia pendidikan kita, dimana pemerintah membuat kebijakan untuk menutup sekolah/madrasah mulai dari tingkat pendidikan usia dini, pendidikan dasar hingga tingkat Perguruan Tinggi. Hal ini tentu saja berdampak pada

${ }^{22}$ Penulis lahir di Surabaya, 22 Juni 1975, penulis adalah Dosen UIN Sumatera Utara dalam bidang ilmu Linguistik, penulis menyelesaikan gelar Sarjana Tadris Bahasa Inggris di IAIN Sumatera Utara (1999), gelar Magister Humaniora diselesaikan di Universitas Sumatera Utara Program Studi Linguistik (2002), dan gelar Doktor Ilmu Linguistik diselesaikan di Universitas Sumatera Utara Fakultas Ilmu Budaya Program Studi Linguistik (2014). 
proses belajar mengajar. Mau tidak mau, suka tidak suka, guru harus berpikir keras untuk memodifikasi pembelajaran dan pengajaran seefektif mungkin walaupun dilaksanakan secara online.

Di samping itu, perubahan yang dialami pada bidang pendidikan dimana pandemi ini menyadarkan kita bahwa mengajar tatap muka itu masih sangat dibutuhkan oleh siswa di Indonesia. Kita sangat membutuhkan peran guru atau pengajar dalam berinteraksi dengan siswanya walaupun melalui perantara gawai yang dinilai belum efektif sepenuhnya. Untuk menjaga agar siswa masih tetap semangat dalam belajar, maka guru dituntut untuk selalu berinovasi dan kreatif untuk meramu materi ajar menjadi sesuatu yang menyenangkan bagi siswa walaupun hanya melalui daring atau online. Pandemi Covid 19 ini seharusnya bukan menjadi penghambat bagi guru untuk menjadi guru ataupun pengajar yang hebat bagi para muridnya yang sedang belajar dari rumah, dan pembelajaran yang disampaikan akan tetap bermakna serta menyenangkan.

Proses pembelajaran daring ini belum begitu populer untuk pembelajaran pada tingkat pendidikan dasar maupun menengah sehingga perlu adanya persiapan yang baik dan guru pun berusaha menemukan cara pembelajaran yang menarik serta menyenangkan agar siswa tidak merasa jenuh ataupun bosan. Hal ini berbeda dengan Perguruan Tinggi dan sekolah yang berstandar internasional yang sudah terlebih dahulu menerapkan pembelajaran dengan menggunakan teknologi jauh sebelum Covid-19 datang. Kini, kehidupan kita tidak dapat dipisahkan dari penggunaan teknologi walaupun di satu sisi juga memiliki pengaruh positif maupun negatif, dan dengan adanya Covid-19 ini memaksa kita khususnya guru/pengajar melakukan proses pembelajaran dengan metode daring yang menyenangkan. 


\section{Menjadi Pengajar Hebat di Situasi COVID-19}

Menjadi pengajar atau guru yang hebat bukan berarti orang tersebut telah memiliki sertifikat pendidik saja, akan tetapi juga harus memiliki kemampuan atau keahlian yang berbeda dengan guru-guru lainnya. Guru yang hebat harus senantiasa memiliki kemampuan dalam menyampaikan materi selanjutnya juga harus berupaya menyentuh hati siswa mengenai manfaat pengajarannya pada kehidupan mereka sehari-hari. Tugas utama dari guru yang super smart itu juga dituntut untuk cerdas dan bisa menjawab segala pertanyaan yang diajukan oleh siswanya, disamping itu guru harus dapat memberikan nasehat, contoh teladan, maupun motivasi yang baik guna membentuk karakter siswa selama dalam proses belajar mengajar berlangsung.

Pada prinsipnya, guru juga merupakan model, semangat dan sumber inspirasi bagi siswanya. Semangatnya guru akan berdampak kepada semangatnya siswa dalam belajar. Oleh sebab itu, guru harus menyiapkan mental untuk menjadi guru yang hebat. Sampai kapanpun peran guru di sekolah tidak pernah bisa digantikan oleh teknologi apapun, guru yang hebat adalah guru yang kewajibannya dilaksanakan dengan sepenuh hati jiwa raganya untuk selalu mencerdaskan siswa-siswanya. Adapun ciri utama guru hebat itu adalah:

1. Ucapannya mudah dipahami dengan intonasi yang jelas.

2. Pengetahuan serta keilmuannya sangat luas dan mendalam.

3. Sederhana serta bersikap lugas.

4. Peduli dan memiliki rasa persahabatan yang tinggi.

5. Memiliki kemampuan media dan metode yang baik.

6. Menjadi guru yang selalu dirindukan siswa.

Dalam proses pembelajaran daring ini pasti bukan hanya siswa yang mengalami kesulitan, akan tetapi dari sisi pengajarpun juga mengalami kendala yang sama. Mengajar 
online pada dasarnya bukanlah merupakan perkara yang mudah, banyak hal yang wajib dikuasai oleh guru dalam mengajar sistem daring/online ini. Percepatan pada sistem pendidikan di era revolusi 4.0 bukan semata-mata hanya belajar melalui online saja, akan tetapi tetap dimodifikasi dengan pembelajaran tatap muka agar blended learning method yang diinginkan tercapai namun tetap tidak bisa diterapkan di masa Covid-19 ini.

Ada berbagai cara yang dapat digunakan di kelas agar pembelajaran daring bisa menyenangkan, yaitu: 1) Menonton film sesuai dengan materi dan bahan ajar, 2) Selalu menggunakan media gambar yang menarik, 3) Membuat game atau puzzle yang menarik dan sesuai dengan materi, serta 4) Membuat video pembelajaran.

Di situasi pandemi Covid-19 ini, ada beberapa langkah yang bisa dilakukan oleh guru yang hebat bagi siswanya, yakni:

1. Berusaha mengenal dan menemukan titik unggul siswa itu sendiri.

2. Selalu mengucapkan kata-kata yang tepat dan baik pada keunggulan siswa.

3. Memberikan suatu kesempatan bagi siswa untuk bereksplorasi dan presentasi di depan teman-temannya.

4. Memberikan motivasi dan label yang baik pada siswa secara individu maupun kelompok.

Sementara itu, ada beberapa keterampilan yang harus dikuasai oleh seorang guru yang hebat ketika mengajar daring/online, seperti:

\section{Keterampilan Memahami Media Online}

Keterampilan ini sangat diperlukan oleh guru terutama mengenai aplikasi dan fitur-fitur yang berkaitan dengan mengajar online, seorang guru harus memilih aplikasi yang mudah dijangkau aksesnya serta tidak membutuhkan kuota yang sangat banyak/besar. 
Gunakan aplikasi yang akrab digunakan oleh siswa seperti aplikasi WhatsApp ataupun email.

\section{Keterampilan Merancang dan Menyajikan Materi Pembelajaran Secara Kreatif}

Guru yang hebat diharapkan mampu menyajikan materi sesuai dengan rancangannya serta menyesuaikannya dengan waktu mengajar online yang sangat terbatas, disini dibutuhkan kreatifitas guru agar saat pembelajaran online ini tidak membuat siswa kurang fokus atau kurang memperhatikan materi saat belajar.

\section{Keterampilan Mengelola Kelas Online}

Pengelolaan kelas online sangat berbeda dengan pengelolaan di ruang kelas saat di sekolah. Gurupun harus tegas dan menegur siswanya bila mengganggu ataupun membuat keributan di kelas online tersebut, atau memberikan pertanyaan kepada siswa tersebut mengenai materi yang sedang didiskusikan. Hal ini dilakukan agar proses pembelajaran online ini dapat berjalan sesuai yang diharapkan sekaligus sebagai bahan evaluasi guru untuk pembelajaran selanjutnya.

\section{Keterampilan Berkomunikasi}

Keterampilan berkomunikasi ini sangat diperlukan dalam menjelaskan materi pada saat mengajar online, terjadinya interaksi guru dan siswa, diskusi maupun tanya jawab seputar pelajaran yang disampaikan, serta bermanfaat pula agar terjalin komunikasi antar guru dengan siswa ataupun antar guru dengan orang tua siswa.

\section{Keterampilan Memotivasi Siswa}

Memotivasi siswa adalah hal penting yang harus dilakukan oleh guru yang hebat, karena dengan motivasi yang baik dan terus menerus akan mengubah siswa dari sifat yang malas menjadi rajin, sifat bodoh menjadi 
pandai maupun membantu siswa bila membutuhkan perhatian dan pertolongan di pelajarannya.

\section{Kesimpulan}

Di masa pandemi ini, semua aktifitas pembelajaran telah dibatasi, pembelajaran yang biasanya dilakukan di sekolah kini harus dilakukan di rumah. Perubahan pembelajaran ini akan menjadi tantangan terberat bagi guru, dimana guru dituntut untuk beradaptasi dengan kondisi ini agar materi yang disampaikan dapat diterima oleh siswa dengan baik. Di sisi lain, pada saat ini pun sistem pendidikan kita telah mengalami berbagai perubahan.

Dengan adanya perubahan ini, maka kita sebagai guru harus menerima kenyataan bahwa cara mengajar kita pun telah berubah. Cara mengajar yang lama tidak bisa kita gunakan secara utuh di kelas daring saat ini. Akan tetapi, pada kenyataannya, dalam mengajar daring ini guru mengalami beberapa tantangan diantaranya yakni kurangnya pemahaman tentang teknologi, adanya fasilitas siswa yang belum memadai, jaringan internet yang baik, kelas yang harus kondusif serta mengajar yang terus berinovasi. Dengan berjalannya waktu, diharapkan guru mampu melakukan pembelajaran online secara efektif sehingga karakteristik guru hebat di masa pandemi ini dapat terwujud.

\section{Daftar Pustaka}

A.Z. Mulyana. (2010). Rahasia Menjadi Guru Hebat Memotivasi Diri Menjadi Guru Luar Biasa. Jakarta: PT Gramedia

Amir, Mirna. 2011. Rahasia Mengajar dengan Kreatif, Inspiratif dan Cerdas. Depok: Logika Galileo

Annisa, A. (2021). Tantangan Guru dalam Proses Pembelajaran Daring di Masa Pandemi Covid-19. 
Program Studi Pendidikan Bahasa dan Sastra Indonesia. Universitas Riau. pp. 1-9.

Davies, Ivor.K. 2000. Pengelolaan Belajar. Jakarta: CV Rajawali

Mulyana. 2010. Rahasia Menjadi Guru Hebat Memotivasi Diri Menjadi Guru Luar Biasa. Jakarta: PT Gramedia

Yuhana, Y. (2020). Tantangan Guru Profesional dalam Melaksanakan Proses Pembelajaran di Masa Pandemi Covid-19. Prosiding Seminar Nasional Pendidikan FKIP, 3(1): 283-288. 


\title{
PROFESI GURU DALAM MENGHADAPI PANDEMI COVID-19
}

\author{
Drs. Yeheskial Nggandung, M.Si. ${ }^{23}$ \\ (Program Studi Pendidikan Ekonomi FKIP Universitas Nusa \\ Cendana Kupang)
}

“Guru merupakan aktor utama dalam pembelajaran oleh karena itu guru harus menguasai IPTEK/IT secara baik agar kualitas pembelajaran daring dapat ditingkatkan."

Denyebaran Corona Virus Disease 19 (Covid 19) yang terajadi sejak awal Maret tahun 2020 di negara kita telah banyak membawa dampak yang positif maupun negatif pada berbagai bidang kehidupan kita. Kita diperhadapkan dengan situasi yang serba sulit akan tetapi kita tidak boleh berdiam diri dengan kondisi yang ada. Harus ada upaya yang tepat agar bisa bertahan dan beraktivtias sesuai dengan profesi masing-masing. Aktivitas di bidang pendidikan dan khususnya proses pembelajaran di sekolah mulai dari tingkat Sekolah Dasar (SD) sampai Sekolah Menengah Umum dan Kejuruan (SMU/K) mengalami dampak yang amat besar akibat pandemi Covid 19.

Kebijakan pertama dari pemerintah untuk meliburkan semua sekolah selama 2 (dua) minggu dan penerapan protokol kesehatan 3M (mencuci tangan dengan sabun di air mengalir, menjaga jarak dan menghindari kerumunan) merupakan upaya untuk menghambat penularan Covid 19.

23 Penulis lahir di Waingapu Kabupaten Sumba Timur, 27 Januari 1963. Menyelesaikan Pendidikan S1 di Universitas Nusa Cendana Kupang, S2 di Universitas Airlangga Surabaya. Saat ini penulis menjadi dosen di Prodi Pendidikan Ekonomi FKIP Universitas Nusa Cendana Kupang. 
Akan tetapi kebijakan ini kurang berhasil dan bahkan pandemic Covid 19 semakin menyebar di seluruh pelosok wilayah negara kita. Kondisi ini sangat kontras dengan perkiraan awal bahwa penyebaran virus hanya terjadi di kota-kota besar yang masyarakatnya memiliki aktivitas dan mobilitas yang tinggi.

Kebijakan meliburkan kegiatan pembelajaran selama 2 (dua) minggu sangat tidak efektif sama sekali, akhirnya pemerintah mengeluarkan kebijakan lain yaitu Pembatasan Sosial Berskala Besar (PSBB) dan yang terakhir Pemberlakuan Pembatasan Kegiatan Masyarkat (PPKM) Darurat atau Level 4 dan Program Vaksinasi Nasional. PPKM telah diperpanjang berulang-ulang dan Level PPKM disesuaikan dengan kondisi penyebaran Covid 19 di masingmasing daerah.

\section{Pelaksanaan Pembelajaran Daring pada Masa Pandemi Covid 19 di NTT}

Pada pertengahan Semester Genap Tahun Pelajaran 2020/2021, pemerintah mengeluarkan kebijakan dimana proses pembelajaran harus dilakukan secara online atau dalam jaringan (daring). Pembelajaran daring merupakan sesuatu yang baru dan bahkan asing terutama bagi guru-guru di Provinsi Nusa Tenggara Timur (NTT). Bagi guru SD terutama yang bertugas di luar kota (pedalaman, terpencil) merasa tidak mampu oleh karena lokasi sekolahnya belum terkoneksi dengan jaringan listrik dan jaringan telekomunikasi (internet) dan belum pernah mengajar secara daring. Demkian pula kondisi guru yang ada di kota tidak semuanya dapat melakukan pembelajaran secara daring karena masih banyak guru yang tidak atau belum menguasai internet dan keterampilan lainnya berkaitan dengan pembelajaran daring yaitu Ilmu Pengetahuan dan Teknologi (Iptek/IT), sehingga walaupun mereka memiliki fasilitas lain seperti smartphone, note book dan laptop.akan tetapi mereka belum bisa mengajar secara daring. 
Pada sisi lain, kemampuna ekonomi orang tua siswa SD di NTT belum mampu menyediakan fasilitas seperti smartphone untuk kebutuhan belajar daring. Hanya sebagian kecil siswa yang memiliki smartphone sehingga membuat pembelajaran daring mengalami kesulitan untuk dilaksanakan secara baik pada daerah-daerah yang berada di pedalaman dan terpencil.

Kondisi guru, siswa dan orang tua seperti ini akan menjadi faktor penghambat dalam pelaksanaan pembelajaran daring. Namun demikian bukan berarti tidak ada jalan keluarnya, guru harus mengambil inisiatif untuk membantu siswa agar pembelajaran tetap berjalan dan tidak menunggu sampai semua fasilitas tersebut tersedia. Di beberapa tempat di NTT pembelajaran secara daring belum terlaksana dengan baik oleh karena ada berbagai keterbatasan tersebut di atas. Dalam hal ini, guru melakukan pembelajaran daring dengan cara mengirim materi pelajaran melalui WhatsApp (WA), sisiwa yang tidak memiliki handphone bergabung dengan siswa yang memiliki handphone, menetapkan titik kumpul dimana siswa dalam satu kelompok akan dikunjungi atau melakukan pertemuan dengan guru untuk menjelaskan beberapa materi yang belum tuntas atau belum dikuasai oleh siswa.

Belum tersedianya jaringan telekomunikasi yang memadai menyebabkan siswa maupun guru pada beberapa daerah tertentu di NTT harus berjalan jauh sekian kilometer untuk mendapatkan tempat yang ada jaringan Telkomsel. Guru maupun siswa membutuhkan waktu dan tenaga untuk mencari jaringan agar mereka dapat menerima pelajaran, mengerjakan tugas-tugas dan mengirim tugas yang telah dikerjakan melalui WhatsApp. Tentu kondisi seperti ini sangat menganggu proses pembelajaran secara daring.

Pelaksanaan pembelajaran daring pada daerah perkotaan pada awalnya disambut secara baik oleh para orang tua murid maupun siswa itu sendiri oleh karena mereka memiliki kompetensi di bidang Iptek dan tinggal di tempat 
yang memiliki fasilitas untuk pembelajaran secara daring. Para orang tua siswa di kota merasa senang karena tidak direpotkan untuk mengantar dan menjemput anak dari sekolah sehingga mereka lebih fokus untuk bekerja dengan lebih tenang oleh karena anak belajar dari rumah

Seiring berjalannya waktu, pembelajaran daring yang awalnya disambut dengan senang oleh orang tua dan siswa yang memiliki fasilitas dan kemampuan di bidang Iptek, akhirnya menimbulkan berbagai keluhan akibat ketidakpuasan terhadap proses pembelajaran daring tersebut. Pengeluhan tersebut antara lain, sebagian besar guru hanya menggunakan menggunakan smartphone dan menyampaikan materi pelajaran dengan mengirim melalui WhatsApp (WA), dan Google Class Room (GCR). Menurut mereka media seperti ini kurang efektif oleh karena hasil belajar siswa tidak dapat dievaluasi secara baik. Bagi siswa terutama pada tingkat $\mathrm{SD}$, orang tua harus berperan sebagai guru yang menerangkan materi yang belum dikuasai dan sekaligus membantu siswa dalam menyelesaikan tugastugasnya sehingga orang tua siswa merasa terbeban dengan profesi baru (menjadi guru di rumah) yang belum pernah mereka jalani sekalipun mereka memikili pendidikan yang lebih tinggi daripada guru yang mengajar anaknya oleh karena mereka tidak memiliki keahlian dan keterampilan untuk menjadi guru yang profesional.

Profesi guru yang awalnya dianggap sepele oleh sekelompok orang menjadi sosok yang sangat penting dan menjadi solusi dalam menghadapi pandemi Covid 19. Selama pembelajaran tatap muka atau di luar jaringan (luring) sering ada keluhan orang tua siswa (tidak semuanya) terhadap guru, dimana guru dianggap sebagai pekerjaan yang gampang dan bisa dilakukan oleh siapapun asalkan memilik tingkat pendidikan yang lebih tinggi. Sering terjadi kasus dimana orang tua siswa tidak menerima perlakuan guru terhadap anaknya walaupun hal itu sangat sepele yang sebenarnya bisa diselesaikan secara baik melalui komunikasi 
antara guru, pihak sekolah dan orang tua. Dalam hal perlu saling menghargai satu sama lain sehingga masalah tersebut tidak berujung pada penyelesaikan secara hukum kecuali masalah yang benar-benar tidak dapat diselesaikan secara kekeluargaan.

\section{Kompetensi Guru dalam menghadapi Pandemi Covid 19}

Dalam Undang-Undang Nomor 14 tahun 2005 tentang guru dan dosen, ditegaskan bahwa guru adalah suatu profesi. Arti dari suatu profesi adalah suatu pekerjaan yang membutuhan suatu keahlian dan keterampilan berkaitan dengan pekerjaannya. Keahlian dan keterampilan dapat diperoleh melalui pendidikan dan pelatihan baik yang dilakukan secara mandiri atau yang dilakukan oleh suatu lembaga dimana guru tersebut bekerja. Selanjutnya dalam UU. Nomor 14 Tahun 2005 pasal 10 ayat 1 "Kompetensi guru meliputi kompetensi profesional, pedagogik, sosial dan kepribadian. Berkaitan dengan keempat kompetensi tersebut maka Kementerian Pendidikan, Kebudayaan, Riset dan Teknologi (Kemdikbudristek) melaksanakan Program Pendidikan Profesi Guru (PPG), pelaksanaan PPG dilakukan oleh Lembaga Pendidikan Tenaga Keguruan (LPTK) yang memuhi persyaratan dari Kemdikbudristek.

Profesi guru dalam menghadap pandemi Covid 19 sangat ditantang untuk melaksanakan pembelajaran daring yang menarik untuk meingkatkan kualitas hasil belajar peserta didik yang tidak kalah bersaing dengan hasil pembelajaran luring. Penguasaan Iptek merupakan salah satu keterampilan yang harus dimiliki oleh guru pada pembelajaran daring. Berkaitan dengan penguasaan Iptek, seorang guru profesional harus menghilangkan pendapat bahwa Iptek itu hanya untuk guru yang mengajar di kota sedangkan guru yang tugas di luar kota yang serba minim fasilitas tidak penting. Kondisi inilah yang membuat para guru terutama yang jauh dari kota enggan belajar untuk menguasai Iptek sehingga ketika pembelajaran daring mereka mengalami kesulitan. 
Penguasaan Iptek akan menghapus sekat dan kesenjangan antara guru di desa dan kota, pemikiran seperti ini harus dihilangkan. Profesi sebagai guru di era globalisasi harus didukung dengan penguasaan Iptek sehingga bisa bekerja dengan memanfaatkan teknologi yang terbaru. Pandemi Covid 19 telah membawa perubahan besar khususnya dalam pembelajaran, sehingga membuat guru tidak harus menunggu kapan baru mulai belajar dan menguasai Iptek. Kondisi mengharuskan siapapun yang berprofesi sebagai guru harus menguasai Iptek sehingga pembelajaran daring dapat dilaksanakan dengan baik. Penguasaan Iptek akan membuat guru lebih percaya diri dalam menghadapi pandemi Covif 19 yang sampai saat ini belum ada solusi yang jitu untuk mengatasi penyebarannya.

Kompotensi profesional berkaitan dengan kemampuan guru terhadap penguasaan materi yang diajarkan. Apabila guru berkompeten di bidang Iptek maka kelangkaan sumber belajar yang selama ini dialami dapat dipenuhi dan diperoleh melalui jaringan internet. Ada banyak sumber belajar yang bisa diakses melalui internet sehingga kualitas hasil belajar dapat ditingkatkan.

Kompetensi pedagogik, penguasaan Iptek dapat membantu para guru untuk memperbaiki model dan metode pembelajaran yang selama ini digunakan dengan mendownload dari internet. Guru dapat menerapkan model dan metode pembelajaran yang menarik dan sesuai dengan tujuan yang ingin dicapai dalam pembelajaran.

Kompetensi sosial berkaitan dengan interaksi antara murid dengan murid, guru dengan murid, guru dengan guru, guru dengan orang tua siswa dan masyarakat. Penggunaan media sosial sebagai sarana komunikasi dalam pembelajaran daring harus dilakukan dengan baik. Komunikasi yang baik dapat membantu siswa untuk menyampaikan hal-hal yang berkaitan dengan materi ajar yang belum dikuasai oleh siswa. Guru harus memberi kesempatan kepada semua siswa dan guru harus bersedia untuk melayani siswa dengan baik. 
Komunikasi akan lebih efektif dan efisien jika guru mengatur jadwal secara baik di luar jam pelajaran.

Kompetensi kepribadian berkaitan dengan tanggung jawab, kejujuran, sabar dan tekun dari seorang guru dalam menghadapi pandemi Covid 19 yang telah menelan korban jiwa manuusia. Guru harus menjadi contoh dan teladan bagi siswa dan masyarakat sekitarnya dalam mematuhi protokol kesehatan. Dalam menghadapi siswa yang sangat terbatas kemampuannya untuk mengikuti pembelajaran daring maka guru harus sabar dan tekun mengajarkan keterampilan yang praktis berkatian dengan Iptek agar siswa memiliki kompetensi untuk mengoperasikan komputer, laptop, note book dan handphone untuk dapat mengikuti pembelajaran daring.

\section{Penutup}

Proses pembelajaran daring selama masa pandemic Covid 19 belum berakhir masih merupakan salah satu solusi yang dapat menahan penyebaran Covid 19. Oleh karena itu berbagai fasilitas pendukung pelaksanaan pembelajaran daring harus tersedia dan merata di seluruh wilayah Negara Kesatuan Republuk Indonesia (NKRI). Guru merupakan aktor utama dalam pembelajaran oleh karena itu guru harus menguasai Iptek/IT secara baik agar kualitas pembelajaran daring dapat ditingkatkan. 


\section{Daftar Pustaka}

Denim, Sudarman dan H. Khairil., 2012, Alfabeta, Bandung.

Satori, Djaman., 2011, Profesi Keguruan, Universitas Terbuka, Jakarta.

Suyono dan Haryanto., 2014, Belajar dan Pembelajaran,PT. Remaja Rosadakarya Offset, Bandung 


\title{
PENGEMBANGAN SUMBER DAYA INSANI DI LEMBAGA PENDIDIKAN ISLAM
}

\author{
Mochamad Fadlani Salam, S.Pd.I, M.Pd. ${ }^{24}$ \\ (Universitas Muhammadiyah Bandung)
}

\begin{abstract}
"Lembaga Pendidikan Islam akan menjadi pilihan yang utama sebagai sarana jihad menegakkan agama Islam, setiap individu harus merasa meiiki sebagai sumber daya manusia di dalamnya, berkemauan untuk selalu bekerja dan berusaha semaksimal mungkin agar lembaganya terus berkembang"
\end{abstract}

embaga Pendidikan Islam bisa diartikan sebagai proses
pengelolaan menajeman pendidikan di dalam lembaga tersebut yang memiliki pola-pola tertentu, dan memiliki struktur organisasi yang dapat mengikat individu yang berada dalam naungannya, sehingga lembaga mampu membuat hukumnya sendiri. Lembaga Pendidikan Islam juga secara umum merupakan suatu wadah untuk menuntut ilmu yang tidak lepas dari aturan-aturan Islam di dalamnya yaitu aturan dalam Al-Qur'an dan Hadits (Luthfi Zulkarnain 2021:245).

Sumber daya manusia pada sebuah lembaga pendidikan Islam, dianggap hanya sebagai aktivitas tempat mengamalkan ilmu dan sebagai tempat untuk mencari kebutuhan nafkah. Persepsi itu tidak sepenuhnya keliru, namun nampaknya perlu dirubah, lebih dari itu, ketika Lembaga Pendidikan Islam diatur dan dikelola dengan baik,

24 Penulis lahir di Bandung, 29 Maret 1986, penulis merupakan Dosen Universitas Muhammadiyah Bandung dalam bdang ilmu Manajemen SDM, penulis menyelesaikan S1 Pendidikan Islam di STAI Muhammadiyah Bandung (2015), dan S2 dengan gelar Magister Pendidikan pada Prodi MPI (Manajemen Pendidikan Islam) diselesaikan di UIN SGD Bandung. 
maka Lembaga Pendidikan Islam akan menjadi pilihan yang utama sebagai sarana jihad menegakkan agama Islam, setiap individu harus merasa meiiki sebagai sumber daya manusia di dalamnya, berkemauan untuk selalu bekerja dan berusaha semaksimal mungkin agar lembaganya terus berkembang.

Disamping itu, lingkup internal dan eksternal organisasi lembaga pendidikan Islam senantiasa mengalami perubahan yang terus menerus, sehingga lembaga pendidikan Islam juga cenderung menuntut berubah secara kontinyu untuk melakukan penyesuaian, diantara penyesuaian tersebut adalah dalam hal manajemen sumber daya manusianya, khususnya masalah pengembangannya yang sesuai dengan kebutuhan organisasi. Untuk itu, terkait pengembanagan SDM (Sumber Daya Manusia) yang merupakan sumber daya uama dalam sebuah organisasi adalah suatu keniscayaan bagi sebuah organisasi lembaga pendidikan Islam, agar menaruh perhatian penuh.

Kemudian, sebelum kita berbicara ke arah pengembangan sumber daya manusia, terlebih dahulu akan dijelaskan terkait pengertian secara umum tentang manajemen. Setelah kita mengetahui pengertiannya secara umum, kemudian kita sandingkan dengan sumber daya manusia, sehingga menjadi lebih khusus.

Penggunaan istilah management sebelumnya identik kaitannya dengan kegiatan pengelolaan, tapi penggunaan istilah tersebut bisa dikatakan hampir jarang lagi dipakai dalam waktu belakangan ini, bersamaan dengan perkembangan ilmu pengetahuan dan ilmu manajemennya secara khusus, sehingga dengan lebih spesifik, pengertian manajemen juga mengalami adanya perubahan, yaitu diantaranya terkait pelaksanaan fungsi-fungsi yang disebutkan bagi seorang manajer untuk menunaikan tugasnya (Mujahid 2003:2).

Menurut Nawawi menjelaskan arti manajemen yaitu berkaitan dengan suatu organisasi yang terlebih dahulu 
merumuskan capaian tujuannya, lalu kemudian dalam mencapai tujuannya tersebut perlu dibantu oleh bantuan orang lain (Hadari Nawawi 2003:36). Hani, menjelaskan bahwa manajemen merupakam ilmu atau seni mengelola sumber daya manusia secara efisien dan efektif dalam pemanfaatannya agar tercapainya tujuan-tujuan tertentu (Hani Handoko 1998:3).

Adapun menurut Umar, merencanakan, mengorganisasikan, menggerakkan, dan juga mengawasi terkait pengadaan, mengembangkan, mengintegrasikan, memberikan kompensasi, memelihara serta memutus tentang hubungan kerja, itu semua merupakan pengertian tentang manajemen sumber daya manusia yang dimaksudkan agar tujuan organisai secara terpadu dapat tercapai (Husein Umar 2001:331). Selanjutnya, dalam kerja organisasi sumber daya manusia itu sangat dominan, maka perlu dilakukan suatu pengembangan untuk meningkatkan kinerja, perilaku, pengetahuan serta keterampilan. Untuk itu, diantara salah satu sub sistem manajemen yang penting untuk mendapat perhatian yang sama dengan sub sistem manajemen yang lainnya dalam lembaga pendidikan Islam adalah manajemen sumber daya manusianya, karena sumber daya manusia salah satu bagian dari kunci keberhasilan sebuah lembaga pendidikan.

Menurut Cecep Darmawan, saat ini ada kebutuhan dasar bagi kita yang tengah mempelajari perilaku manusia atau manajemen sumber daya manusia. Kebutuhan ini, yakni merumuskan kembali hakikat manusia, dan atau tentang potensi dasar dari manusia. Tentunya jika hal ini tidak kita lakukan, asumsi dan premis-premis tentang manusia tidak sesuai dengan hasil-hasil temuan terbaru, atau dengan orientasi pengembangan sumber daya kecerdasan itu sendiri. Sebab, pengertian manusia selama ini, baik dibidang psikologi maupun sosiologi-antropologi, masih diwarnai oleh nilai-nilai positivisme dan cognitivis (Cecep Darmawan 2006:3) 
Ada tiga kategori ungkapan yang dipakai oleh al-Qur'an atau istilah yang dipakai untuk menunjukkan konsep tentang manusia, diantaranya adalah: a) al-'ins, al-nas, unas, insiy, anasiy,dan al-insan; b) basyar; dan c) dzuriiyat adam "keturunan adam" atau bani adam "anak adam" (M. Quraish Shihab 2006:278). Senada dengan yang dijelaskan oleh Rifat Syauqi bahwa al-Quran memakai istilah ins atau insan, unas atau al-nas, bani adam juga basyar untuk menjelaskan arti dari manusia (Rifat Syauqi 2000:5).

Dari hasil pengkajian yang dilakukan Cecep Darmawan bahwa konsep yang lebih tepat untuk menunjukkan 'manusia' yang lebih lengkap adalah insan. Sebab, di dalamnya terkandung makna makhluk basyariyyah yang menunjuk pada aktivitas biologis, fisiologis, atau material dan juga aktivitas insani yang berkaitan dengan aktivitas ruhaniah dan intelektual. Sementara penggunaan konsep manusia, dalam arti 'bahasa Indonesia' tidak ditemukan penjelasan yang pasti tentang keakurasian penggunaannya (Cecep Darmawan 2006:10).

Kemudian, untuk meningkatkan kompetensi kinerja manusia dalam lingkup pegawai atau karyawan pada waktu yang akan datang, dalam menyiapkan diri dan dalam menunaikan tanggung jawabnya, perlu adanya latihan secara sistematis melalui proses belajar, dan inilah yang dirumuskan dalam pengembangan sumber daya manusia (Achmad S. Ruky 2006:227). Upaya peningkatan dalam kemampuan konseptual, kemampuan teoritis, kemampuan teknis, juga kemampuan sikap, harus ada dalam bagian sebuah pengembangan sumber daya manusia. Dan, agar ini dapat tercapai tujuan organisasinya, maka mesti disusun dalam sebuah rencana yang sistematis, cermat sesuai kebutuhan personal dan institusional, serta memakai metode ilmiah tertentu (Sunhaji 2008:29).

Adapun diantara cara-cara dalam mengembangkan kualitas sumber daya manusia yaitu: a) Berinisiatif mengembangkan diri sendiri dalam memperoleh 
keterampilan dan pengetahuan, b) Menjalani proses di tempat kerja pada program yang sisteamtis terkait pelatihan dan pendidikan, c) Mengikuti proses pendidikan dasar sampai dengan pendidikan tinggi (Nasir Usman 2012:17).

Selanjutnya terkait dengan pengembangan sumber daya insani di lembaga pendidikan Islam, penulis mengutip QS. AlJumu'ah:2, ini adalah pola pendidikan pengembangan sumber daya insani yang dilakukan oleh Rasulullah saw yang diwujudkan dalam empat jenis metode pembinaan dan pelatihan, keempat metode tersebut adalah; tilawah (membaca qur'an), ta'lim (pengajaran kitab-kitab), tazkiyah (restropeksi), dan hikmah (hidden education).

Metode tilawah (membaca qur'an), implikasi praktisnya yaitu membudayakan membaca qur'an sebagai pembinaan psikologis para insan pekerja. Dalam keyakinan Islam, frekuensi membaca qur'an memiliki implikasi praktis terhadap kualitas keshalehan pribadi. Implikasi yang kedua, proses pembinaan ini dapat dilakukan dengan cara mengajak karyawan atau pegawai untuk membaca ayat Allah dalam arti fakta sosial (Cecep Darmawan 2006:94).

Metode ta'lim (pengajaran kitab-kitab), implikasi praktisnya yaitu mengedukasi lewat bacaan dan pengajaran al-Qur'an tentang etos kerja yang baik. Wujud teologisnya, ta'lim dapat dimaknai bahwa lingkungan lembaga perlu mensosialisasikan secara intensif dan periodik, terkait teoriteori, nilai-niai, tata tertib, aturan, kiat kerja produktif, kiatkiat sukses yang harus ada (Cecep Darmawan 2006:95-96).

Metode tazkiyah (restropeksi), implikasinya adalah memberikan pelatihan kepada sumber daya insani dalam rangka elminasi antara prilaku atau kinerja yang baik dan buruk. Hasil data evaluasi yang nanti akan dikembangkan dalam metode tazkiyah ini, bagi proses pembinaan dan pendidikannya. Pimpinan wajib menjelaskan kepada karyawannya tentang peta kinerja mereka kategori prilaku 
apa-apa saja yang mesti diperbaiki, dan dijelaskan dengan cerdas serta kritis (Cecep Darmawan 2006:96-97).

Metode hikmah (hidden education), digunakan untuk menunjukkan pengetahuan filosofis seperti orang yang berfilsafat biasa disebut ahli hikmah. Pendekatan hikmah ini merupakan suatu karakter kemampuan untuk menarik hidden education (pelajaran tersembunyi) yang didapat dari suatu kejadian. Kecerdasan karakter yang dimaksud merupakan sebuah kecerdasan yang arif dalam mendapatkan makna pada sebuah kenyataan atau gejala fenomena yang ada (Cecep Darmawan 2006:97-98).

\section{Daftar Pustaka}

Darmawan. Cecep. 2006. Kiat Sukses Manajemen Rasulullah; Manajemen Sumber Daya Insani Berbasis Nilai-Nilai Ilahiyah. Bandung: Khazanah Intelektual.

Handoko. Hani. 1998. Manajemen Personalia Dan Sumber

Daya Manusia Edisi 2. Yogyakarta: BPFE.

Mujahid. 2003. Manajemen Madrasah Mandiri. Jakarta: Puslitbang.

Nawawi. Hadari. 2003. Manajemen Strategik: Organisasi NonProfit Bidang Pemerintahan Dengan Ilustrasi Di Bidang Pendidikan. Yogyakarta: Gadjah Mada University Press.

S. Ruky. Achmad. 2006. Sumber Daya Manusia Berkualitas. Jakarta: Gramedia Pustaka Utama.

Shihab. M. Quraish. 2006. Wawasan Al-Qur'an Tafsir Maudhu'i Atas Perbagai Persoalan Umat. Bandung: Mizan.

Sunhaji. 2008. Manajemen Madrasah. Jakarta: Grafindo Litera Media. 
Syauqi. Rifat. 2000. Konsep Manusia Menurut Al-Qur'an Dalam Metodologi Psikologi Islami. Yogyakarta: Pustaka Pelajar.

Umar. Husein. 2001. Strategic Management in Action. Jakarta: Gramedia Pustaka Utama.

Usman. Nasir. 2012. Manajemen Peningkatan Mutu Kinerja Guru, Konsep, Teori, Dan Model. Bandung: Citapustaka Media Perintis.

Zulkarnain. Luthfi. 2021. "Analisis Mutu (Input Proses Output) Pendidikan Di Lembaga Pendidikan MTs Assalam Kota Mataram Nusa Tenggara Barat." Jurnal Manazhim 3:17-31. doi: https://doi.org/10.36088/manazhim.v3i1.946. 


\title{
OPTIMALISASI PERAN PENGAWASAN ORANGTUA DALAM MENINGKATKAN PELAKSANAAN PEMBELAJARAN ONLINE DI ERA PANDEMI COVID-19
}

\author{
Abdul Khamid, M.Pd ${ }^{25}$ \\ (Institut Agama Islam Negeri Salatiga)
}

"Dalam pembelajaran secara online ditengah-tengah wabah pandemi covid-19 diperlukannya kerjasama ditingkatkan kembali, orangtua tidak boleh lengah dan selalu memantau, menagawasi putra-putrinya"

K ita ketahui bersama pada akhir Tahun 2019 dunia digemparkan dengan munculnya virus covid-19 yang telah menyebabkan lonjakan angka kematian yang cukup tinggi. (Nawal El- Zuhby: 2021), sehingga duniapun ramai membincangkan wabah pandemi covid-19 yang belum tau kapan berakhirnya, akhir-akhir ini masih didapati lonjakan penderita covid-19. Penyebaran virus mematikan skala dunia ini yang kita ketahui bersama pertama kali muncul di kota Wuhan, Cina, virus tersebut dengan cepatnya menyebar ke lebih dari 200 Negara di seluruh dunia, termasuk salah satunya adalah Negara Kesatuan Republik Indonesia yang mayoritas warganya beragama Islam. (Wachyudi Achmad, 2020).

\footnotetext{
${ }^{25}$ Penulis lahir di tanah kelahiran yang berada di Kabupaten Grobogan. Penulis menyelesaikan Pendidikan sarjana Pendidikan Agama Islam IAIN Salatiga (2017). Kemudian melanjutkan ke jenjang Magister Pendidikan Agama Islam IAIN Salatiga lulus Tahun (2019). Saat ini penulis tercatat sebagai Dosen aktif di IAIN Salatiga, selain dikampus penulis juga mengajar di salah satu Madrasah Tsanawiyah Swasta dan juga mengajar di salah satu Pondok Pesantren yang berada di Kabupaten Semarang Jawa Tengah.
} 
Berbagai otoritas kesehatan semua dikerahkan mulai dari pusat pengendalian dan pencegahan wabah Amerika Serikat (CDC) hingga badan kesehatan Dunia (WHO) selalu mengingatkan akan selalu pentingnya tinggal dirumah terlebih dulu selama ganasnya virus menyerang dunia. Sejumlah kalangan juga ikut andil memberikan respon terhadap fenomena munculnya virus corona ini mulai dari kalangan pemerintahan, ilmuan dan agamawan. Pemerintah dengan kekuasaannya telah menetapkan PSBB untuk memeutus rantai penyebaran virus. Beberapa kebijakan lain diantaranya merumahkan para pelajar dan mahasiswa untuk belajar dirumah sementara, menunda kegiatan-kegiatan yang melibatkan banyak kerumunan banyak orang, serta hal-hal yang sifatnya mengundang berbagai kerumunan banyak manusia. (Moh. Shofan, 2020).

Berbagai kebijakan pemerintah Indonesiapun diterapkan, pemerintah mempunyai otoritas kekuasaan untuk memutus rantai penyebaran wabah pandemi covid-19 diantanya halhal yang dilaksanakan pemerintah pemberhentian sementara pembelajaran tatap muka digantikan dengan pembelajaran online dengan mengedepankan pemanfaatan teknologi yang berkembang saat ini. Digiatkannya pemahaman kepada masyarakat akan pentingnya menjaga kesehatan dan diperlukannya hidup dengan melaksanakan 5M (memakai masker, mencuci tangan, menjahui kerumunan, menjaga jarak, dan membatasi mobilitas).

Dalam hal ini bermula munculnya virus mematikan ini tentunya memberikan sebuah dampak yang sangat besar akan berlangsungnya kegiatan ekonomi, kesehatan dan bahkan dunia pendidikan. Saat ini kita menyadari betul dan melihat bersama kegiatan pembelajaran dilakukan secara tatap muka di sebuah ruangan kelas, kini semua pembelajaran dilaksanakan dalam jaringan (online). Pembelajaran seperti ini pada awalnya memang tidak dikehendaki oleh banyak oaring apalagi dunia pendidikan dasar, namun dengan adanya wabah ini semua orang harus 
benar-benar mau menyadari dan ikut bersama melaksanakan pembelajaran online. (Rahmat Rifai dkk, 2020), dengan harapan segera berakhirnya penyebaran virus dan dunia kembali normal pendidikan kembali keruang-ruang kelas sehingga pembelajaran lebih mengarah kepada tataran Uswatun Hasanah dari pengajar kepada peserta didik.

Berbagai kasus dalam dunia pendidikan dilaksanakan menggunakan sistem online secara keseluruhan cukup berat yang dirasakan orangtua wabil khusus pendidikan Dasar yang belum begitu terbiasa belajar menggunakan pemanfaatan teknologi, sehingga perlunya pendampingan dan pengawasan dari orangtua dalam pelaksanaan pembelajaran. Dengan berbekal permaslahan tersebut penulis memfokuskan tujuan penulisan ini untuk memberikan tambahan literature riview pembelajaran online dan peranan penting orangtua dalam mengoptimalkan pengawasan dalam membimbing serta mengarahkan putraputrinya selama pelaksanaan sekolah online di masa pandemi saat ini.

\section{Peran Penting Pengawasan Orangtua dalam Mengoptimalkan Pembelajaran Online di Masa Pandemi}

Masalah demi masalah mendewasakan semuanya dalam mengatasi sebuah problematika, saat ini setelah adanya virus covid-19 menjadikan sebuah permasalahan yang cukup berat dikalangan dunia pendidikan yang harus melaksanakan pendidikan melalui jejaringan yang sebelumnya belum pernah dilaksanakan. Dalam sebuah kasus tersebut hal yang paling cukup berdampak adalah pendidikan di sekolah Dasar yang masih minimnya akan penggunaan media pembelajaran secara online.

Dorongan dari orangtua dalam ikut serta menyukseskan pembelajaran online ini sangat diperlukan dengan dukungan kegiatan belajar di rumah serta dikombinasikan dengan keterlibatan seorang guru sangatlah penting untuk dilaksanakan guna tetap berlangsungnya pendidikan 
ditengah-tengah wabah pandemi covid-19. Disisi lain orang tualah yang mempunyai tanggungjawab pertama kali dalam mendidik anaknya sehingga diperlukannya kemitraan antara orangtua terhadap sekolah guru yang efektif sehingga tertanamlah jiwa orangtua tentang berbagai manfaat atas keterlibatan orangtua dalam mendidik dan mengawasi putraputrinya. Seperti yang pernah dikatakan oleh seorang muller mengatakan bahwa: "Kemitraan keluarga, sekolah dan masyarakat sedang mendifinisikan kembali batas-bats dan fungsi-fungsi pendidikan. Mereka memperbesar kapasitas orang tua dan komunitas, mereka menciptakan kondisi dimana anak-anak belajar lebih efektif. Dengan cara ini mereka mengambil pendidikan di luar gerbang sekolah" (Muller, 2009).

Dampak dalam kasus ini memanglah sangat berat terhadap orangtua pembelajaran dalam penggunaan internet (online), permasalahan-permasalahan yang dirasakan kebanyakan orangtua sangatlah beragam, adakalanya yang membengkaknya pengeluaran paket data guna memfasiltasi anak semata-mata menginginkan proses belajar mengajar anak tetap lancar, selain itu ada juga permasalahan dari orantua masalah waktu yang terkadang terbentur dengan waktu kerjanya orantua. Hal ini menjadikan beberapa dampak yang dirasakan banyak dikalangan orangtua murid sekolah Dasar saat ini, belum lagi anak-anak belum mahir dalam mengakses internet sehingga perlunya pendampingan dan pengawasan.

Dengan demikian diperlukannya trobosan-trobosan yang lebih menarik dan efektif dengan harapan proses belajar mengajar anak tetap berjalan lancar orangtua ikut serta mendampingi dan mengawasi dalam pembelajaran online. Hal tersebut memanglah berat untuk dilaksanakan secara keseluruhan, akan tetapi disaat pandemi seperti ini kebijakan tersebut harus kita patuhi guna memutus penyebaran virus corona. 
Menggapai semuanya itu dibutuhkannya pengorbanan orangtua dan ada beberapa alternatif yang dapat dilaksanakan orangtua sebagai bentuk bagian dari perhatian dan pengawasan terhadap putra-putrinya selama pelaksanaan pembelajaran online di tengah-tengah merebaknya wabah virus corona. Hal-hal tersebut diantaranya pertama, selalu sabar: meskipun pada masa saat ini kebanyakan dari anak-anak susah untuk dibangunkan dengan dalih tidak berangkat sekolah, maka orantua harus tetap bersikap sabar terhadap anak dan membangunkan secara pelan-pelan, jika didapati anak malas dalam mengerjakan tugas-tugasnya dihadapan anak orangtua menunjukan sikap sabar dan tidak mudah emosian dihadapan anak-anaknya. Kedua, selalu mengajak disiplin: dalam hal ini meskipun anak tetap dirumah selama pembelajaran online, orantua harus tetap memberlakukan anaknya untuk selalu melaksanakan kebiasaan-kebiasaan baik misalnya bangun pagi, mandi, sarapan dan melihat jadwal setelah itu suruh mengikuti pembelajaran secara virtual, dengan harapan anak tetap melaksanakan kegiatankegiatan dengan teratur dan disiplin. Ketiga, orangtua mendamping putra-putrinya: orangtua sangatlah penting dalam pemantauan pembelajaran anak secara virtual, dibiasakan pengawasan sebelum dan sesudah pelaksanana pembelajaran, dan selalu memastikan materi yang sudah diajarkan oleh guru-gurunya anak sudah bisa dimengerti dan dipahami. Keempat, perlunya ada evaluasi bersama: sangatlah penting dalam kegiatan apapun diperlukannya adanya tindakan evaluasi, dalam pembelajaran secara virtual atau online ini sudah berjalan efektif atau belum, diperlukannya evaluasi bersama anatara siswa, guru, dan orangtua, jika didapati kekurangan dalam proses pembelajaran vritual atau online maka hal tersebut perlunya diskusi dan mencari solusi bersama guna tetap berjalannnya pembelajaran secara virtual atau online di tengah wabah pandemi covid-19. Hal ini akan terpupuk dengan baik sebuah 
komunikasi antara siswa, guru, dan orantua selama kegiatan tersebuat diaadakannya sebuah evaluasi bersama.

Dengan demikan dalam pembelajaran secara online ditengah-tengah wabah pandemi covid-19 diperlukannya kerjasama ditingkatkan kembali, orangtua tidak boleh lengah dan selalu memantau, menagawasi putra-putrinya, begitu juga seorang guru diperlukannya tangkas dalam hal perubahan pola pengajaran, guru dituntut lebih kreatif dan menarik dalam menyusun dan mengembangkan metode pembelajaran denagan pemanfaatan teknologi internet yang berkembang saat ini selama pembelajaran online berlangsung.

\section{Daftar Pustaka}

Achmad Wachyudi. (2020) "Peran dan Tantangan Pendidikan Agama Islam di Era Pandemi Covid-19 pada Lingkungan Keluarga".JIE: Journal Of Islamic Education. Vol. 5 No.2Diaksesdi http:// www.ejournal. stitmuhbangil.ac.id/ index.php/jie/artcle/view/188

Moh Shofan. (2020) "Agama, Sains dan Covid-19: Mendialogkan Nalar Agama dan Sains Modern". Jurnal MAARIF Institut. Vol. 15 No. 1 Tahun 2020.

Nawal El-Zuhby. (2021) "Tafakur Pandemi Covid-19 Pesepektif Pendidikan Islam". Fikroh: Jurnal Pemikiran dan Pendidikan Islam. Vol. 14 No. 1 Tahun 2021. Diakses di: https//jurnal. Staialazharmenganti.ac.id/index.php/fikroh

Lubis Rifai Rahmad dkk. (2020) "Alternatif Startegi Pembelajaran Selama Pandemi Covi-19 Di STAI Sumatra Medan". Ansiru: Jurnal PAI. Vol. 4 No. 1. Diakses di http://www.jurnal.unisnu.ac.id

Muller, A. (2009) "Framing Childhood In Eigteenth-Century English Periodicals and Prins, 1689-1789". United Kindom: Ashgate Publishing. 
172 


\title{
PENINGKATAN KUALITAS PENDIDIK MENUJU SUMBER DAYA MANUSIA YANG UNGGUL DAN BERMARTABAT DALAM BIDANG PENDIDIKAN DI MASA PANDEMIK COVID-19
}

\author{
Fitri Anjani,S.Pd. ${ }^{26}$ \\ (SDN Wonokusumo Mojosari Mojokerto)
}

\begin{abstract}
"Pendidikan yang berkualitas adalah pendidikan yang dapat menghasilkan lulusan yang memiliki kemampuan dasar untuk belajar, sehingga dapat mengikuti pembaharuan dengan perubahan dengan cara memberdayakan sumber-sumber pendidikan secara optimal melalui pembelajaran yang baik dan kondusif"
\end{abstract}

$\mathrm{U}$ ntuk meningkatan kualitas sumber daya manusia dalam bidang pendidikan, harus adanya peningkatan sumber daya manusia yang unggul dan bermartabat dengan tujuan mencetak generasi-generasi yang unggul dan siap bersaing dalam dunia pendidikan. Pada masa pandemik covid -19 sangatlah berpengaruh dalam bidang pendidikan, tidak cukup di sekolah saja tetapi semua instansi untuk dapat lebih berinovatif untuk meningkat keprofesional sumber daya manusia dapat menciptakan dan menerapkan strategi strategi dalam upaya peningkatan kualitas sumber daya manusia khususnya pendidik di dunia pendidikan ini.

${ }^{26}$ Penulis lahir di Mojokerto, 22 Agustus 1980, penulis adalah guru SD sejak Tahun 2003, s/d Tahun 2012 di Perbantukan di SD Muhammadiyah Mojosari, pada Tahun 2012 penulis secara Otoda penulis dikembalikan Ke SDN Sumbertanggul 1 Mojosari, padaTahun 2013 penulis mendapatkan perintah tugas ke di SDN Wonokusumo Mojosari, penulis menyelesaikan gelar Sarjana Ilmu Kependidikan di Universitas Muhammadiyah Surabaya (2005). 
Dengan perkembangan teknologi di era digital saat ini pendidik dituntut untuk belajar dan menguasai IT untuk meningkatan kualitas yang unggul dalam menyampaikan pembelajaran yang menyenangkan bagi peserta didik yang saat ini melaksanakan pembelajaran daring. Dengan kualitas sumber daya manusia dapat meningkatkan kinerja dan pelayanan masyarakat khususnya bidang pendidikan. Dengan keprofesional dapat membentuk siswa yang produktif, berkarakter, berbudi luhur, kreatif, berkarya dalam menghadapi semua tantangan di bidang pendidikan di masa akan datang. Dalam masa pandemik ini teknologi sangat berpengaruh di semua kalangan yang harus kita sikapi dengan sikap positif. Sehubungan dengan pencerdasan bangsa, khususnya pendidik para pendidik di Indonesia, harus mengoptimalkan hasil peningkatan kualitas sumber daya manusia, berwawasan luas untuk kemajuan peserta didik. Pendidik memegang peranan penting dalam menyiapkan program-program atau strategi dalam pengajaran secara daring yang menghasilkan siswa-siswa siap memasuki era generasi muda yang mempunyai daya saing yang berkualitas, serta diharapkan generasi muda mampu berkontribusi dalam persaingan global yang lebih pesat lagi di tahun-tahun depan.

Selama masa pandemik, banyak keahlian baru yang diciptakan oleh para pendidik untuk memaksimalkan untuk beradaptasi dengan situasi sekarang, dalam bidang pendidikan di negara ini di harapkan pendidik di Indonesia dari sabang sampai merauke diharuskan untuk memiliki optimisme tinggi dan produktif dalam proses pengajaran yang bisa dijadikan kiat untuk mencari keberkahan dan keridhohan dari musibah nasional wabah pandemik Covid19, yang dapat menciptakan inovasi, kreativitas baru, dan berkarya dalam bidang pendidikan di Indonesia. Dalam semboyan "Belajar sepanjang hayat (life long education)" disamping itu juga kita harus memperhatika 4 pilar utama pendidikan yang dicanangkan UNESCO yaitu; Learning to 
knowl, learning to do, learning to be, learning to live together. Seorang pendidik pada saat ini harus menghadirkan transformasi pembelajaran dari materi ke materi, serta memiliki kecakapan hidup, antara lain ketrampilan komunikasi, pemecahan masalah, menyerap informasi, berpikir kritis,dan berinovasi untuk berkarya untuk perkembangan peserta didik, jangan sampai seorang pendidik hanya memberikan tugas siswa terpaku pada LKS, buku-buku saja sehingga menimbulkan kritik dari wali murid yang tidak seharusnya pendidik terima,dan menciptakan sikap kejenuhan pada pembelajaran daring atau online. Seorang pendidik harus bisa menjadi sebagai jembatan emas untuk membangun peserta didik untuk mempunyai kecakapan hidup (life skill), karakter, menciptakan kompetensi dan menggerakan literasi (calistung, baca, literasi digital, literasi berakarakter,dsbnya), sehingga pendidik mempunyai mindset untuk pemberian pembelajaran secara online ataupun yang akan datang masa new normal.

Dalam peningkatan kualitas pendidik menggunakan strategi dalam proses keberlangsungan pendidikan pada masa pandemik covid -19 ,sehingga dapat memacu prestasi pendidikan kita kian lebih baik dan meroket, diantaranya di era pandemik sekarang ini, pendidik harus dapat mengikuti pengembangan diri untuk memperdalam ilmu atau ketrampilan untuk menunjang keprofesian berkelanjutan, berbagai hal dilakukan oleh seorang pendidik dapat meningkatkan profesionalismenya. Sesuai Peraturan Menteri Negara Pendayagunaan Aparatur Negara dan Reformasi Birokrasi Nomor 16 Tahun 2009, seorang guru dapat melakukan kegiatan sebagai berikut:

1. Merencanakan dan melaksanakan pembelajaran, mengevaluasi dan menilai hasil pembelajaran, menganalisis hasil pembelajaran, melaksanakan tindak lanjut, 
2. Melaksanakan tugas yang relevan dengan fungsi sekolah madrasah,

3. Melaksanakan pengembangan diri,

4. Melaksanakan Publikasi Ilmiah,

5. Melaksanakan Karya Inovatif.

Dalam upaya peningkatan kualitas pendidik secara formal dapat menciptakan sumber daya manusia peserta didik untuk megoptimalkan tiga ranah potensi peserta didik, yaitu kognitif, afektif, dan psikomotor sesuai dengan kemampuan masing-masing dan sebagai penerus generasi bangsa meningkatkan keprofesional diri diantaranya seminar, lokakarya, webinar dan bimtek yang diadakan oleh kemendikbud yang mudah diakses pada SimPKB, Kominfo dengan mudah untuk diikuti, atau pengembangan diri dari lembaga-lembaga lain yang berkaitan dengan peningkatan kualitas pendidik. Selain mengikuti pengembangan diri pendidik dapat menyampaikan materi dengan berbagai cara melaksanakan pembelajaran secara virtual, dengan tujuan membangun literasi digital. Para Pendidik harus bisa melakukan inovasi dan strategi dalam masa pandemik covid 19, sehingga dapat memacu prestasi pendidikan kita kian lebih baik dan meroket, diantaranya kita memakai aplikasi zoomeeting dalam penyampaian materi sehingga siswa senang bisa saling komunikasi secara virtual, video channel pembelajaran, semua elmen dipaksa untuk beradaptasi dengan kenormalan saat era pandemik sekarang ini. Selain menerapkan,video channel zoomeeting pendidikan juga menyampaikan melalui kelas virtual guru inovatif Indonesia salah satunya guru "membuat website pembelajaran dengan google sites" dapat mengembangkan situs sendiri dalam membuat website dan isinya, yang terintegrasi perangkat google lain,gratis penyimpanan online sampai 100MB,sehingga tersimpan di server keamanan google,contoh tampilan google sites sebagai berikut:

1. Tampilan google sites 


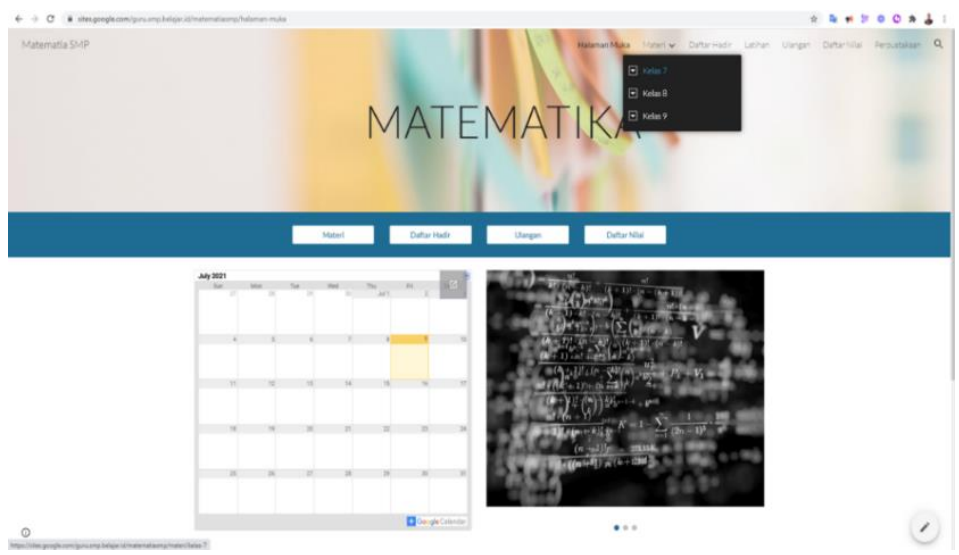

2. Kelebihan google sites

Hosting Gratis, Domain Gratis Drag and Drop tanpa pemrograman , Layanan google lainnya

3. Cara akses Google Sites $=$ Google Drive
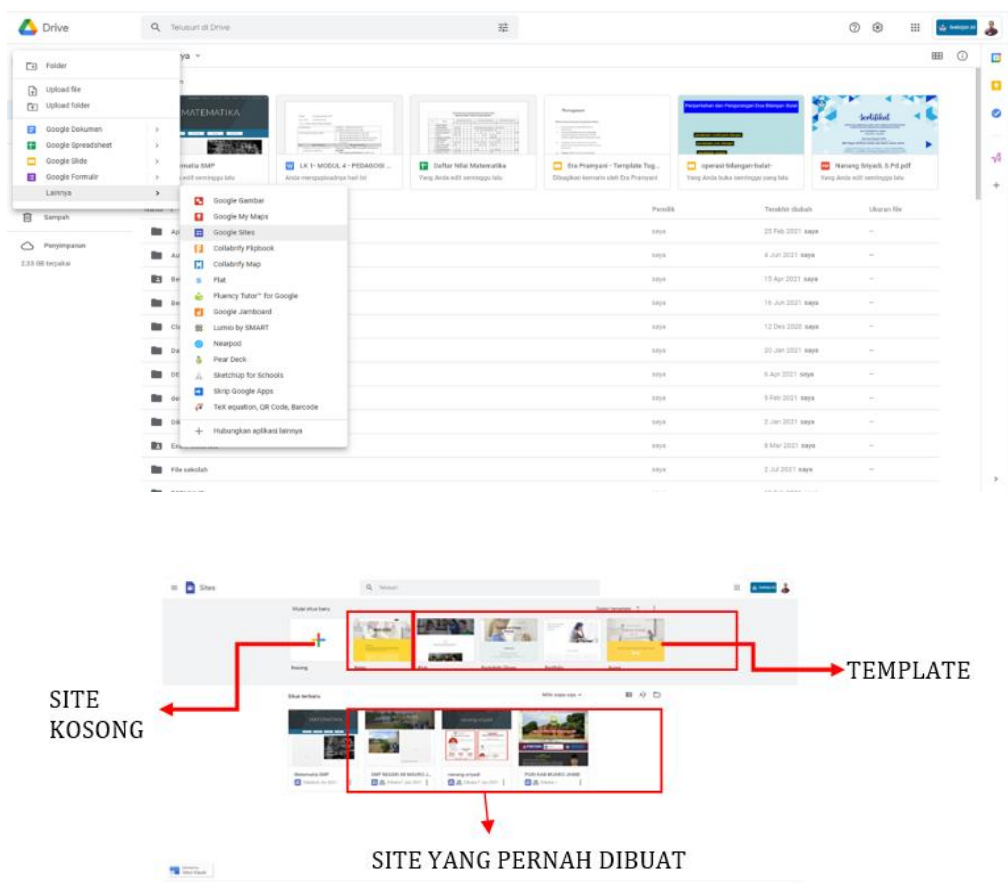
Jadi pendidikan yang berkualitas adalah pendidikan yang dapat menghasilkan lulusan yang memiliki kemampuan dasar untuk belajar, sehingga dapat mengikuti pembaharuan dengan perubahan dengan cara memberdayakan sumbersumber pendidikan secara optimal melalui pembelajaran yang baik dan kondusif, yang disampaikan oleh sumber daya manusia (pendidik) yang berkualitas dan unggul sehingga tercipta sekolah yang berprestasi, sekolah yang baik ,sukses, efektif yang mampu bersaing dengan siswa di luar sekolah.

\section{DAFTAR PUSTAKA}

Permen PAN dan RB .16 Tahun 2009 tentang Jabatan Fungsional Guru. Undang-Undang Nomor 20 Tahun 2003, Sistem Pendidikan nasional Jakarta;Depdiknas Putri.2010.Upaya Meningkatkan Mutu dan Kualitas Guru Riswadi,Ahmad.Masudi.2021. Upaya Meningkatan Kualitas Guru

Undang-Undang Republik Indonesia Nomor 14 Tahun 2005 Tentang Guru Dan Dosen.2006.Jakarta:Eka Jaya. 


\title{
PENDIDIKAN KEMANDIRIAN ANAK DI MASA PANDEMI COVID-19
}

\author{
Hj. Mukhlishah. Dra. M.Ag. ${ }^{27}$ \\ (Universitas Muhammadiyah Bandung)
}

"Pendidikan keluarga sebagai basis pendidikan awal memiliki kesempatan besar untuk memberikan ruang pada anak untuk mengeksplorasi, membantu dan memberikan arahan-arahan yang menekankan arti penting pendidikan kemandirian"

Kita semua merasakan disrupsi khususnya pada Ipendidikan di masa pandemi ini. Perbagai pola kehidupan drastis berubah, ekonomi, politik, sosial dan budaya. Pandemi tidak hanya mengancam keselamatan fisik tapi juga psikologis manusia. Meski respon setiap orang berbeda sesuai dengan kadar life skill yang mereka miliki. Pandemi bisa berarti berkah dan kemajuan atau menjadi benar-benar bencana. Pada tingkat pendidikan tinggi misalya , beberapa penelitian menunjukkan angka stres mahasiswa indonesia dalam pembelajaran mencapai di atas 50 persen (Rifa Fauziyah: 2021). Pada level pendidikan menengah ke bawah pun tak lepas ditenggarai ketidakmampuan orang tua, stres anak-anak dalam menghadapi pembelajaran daring dan penugasan dari guru yang dinilai tak sesuai dengan kemampuan anak, beberapa penelitian menunjukkan hal tersebut.

27 Penulis lahir di Bandung 28 Februari 1964, Penulis adalah dosen di Universitas Muhammadiyah Bandung program studi Pendidikan Agama Islam. Selain mengajar, penulis aktif mengisi seminar parenting sebagai pembicara. Penulis menyelesaikan pendidikan S1 fak tarbiyah di IAIN SGD Bandung pada 1988, dan S2 Manajemen Pendidikan Islam di Universitas Islam Bandung pada 2002. 
Setiap keluarga memiliki tanggung jawab dalam mempersiapkan anak dalam hal kemandirian, intektualitas, kecerdasan sosial dan spiritual. Terlepas adanya pandemi atau tidak, orang tua memiliki tanggungjawab mempersiapkan untuk mandiri anak semenjak dini. Namun demikian pendidikan kemandirian ini seketika kurang diperhatikan ketika anak sudah bisa melakukan hal hal sederhana dari mulai memakai baju, mandi makan, minum dan aktivitas lainnya tanpa bantuan orang tua. Pada pendidikan anak usia dini, kamandirian ini nyaris tak tersentuh lagi jika anak sudah mampu melakukan hal hal sederhana secara mandiri dan tidak bergantung pada orang tua atau guru. Padahal life long education tentu saja menyasar dan menuju pada pendidikan kemandirian itu sendiri dengan pancapaian kematangan manusia dalam berfikir, bersikap dan mengasah rasanya.

Rupanya selama ini peran peran penting orang tua sebagai pendidik utama, teladan dan madrasah awal bagi anak-anaknya banyak diabaikan, rerata tanggung jawab pendidikan sudah dianggap cukup dengan cara didelegasikan kepada yang lain atau lembaga pendidikan tertentu. Di sisi lain covid- 19 mendisrupsi hal tersebut, beberapa orang tua mau tak mau harus terlibat pada proses pendidikan anak yang semula ditinggalkan itu, sehingga baru disadari bahwa proses mendidik tidaklah mudah. Di sini pandemi bisa diartikan musibah bila orang tua tak segera memperbaiki pola didik dan asuh anak-anaknya, dan akan menjadi berkah bila beberapa kanal komunikasi orang tua anak-guru dibuka, pikiran dan kepekaan rasa diasah, kreativitas dan insight supaya pembelajaran membosankan terus dilakukan.

Dalam beberapa kasus kita akan mudah menemukan contoh kasus misal orang tua yang membantu anaknya bahkan pada perkara yang paling remeh (misal mengasah pensil) meski anaknya sudah berumur 8 tahun . ini terjadi pada ibu W ( 30 tahun), ia memiliki anak bernama $\mathrm{F}$ (8 tahun) ketika pembelajaran di mulai secara online atau ada 
intruksi dari guru anaknya ia segera dengan aktif menangani dan tak jarang ia sendiri yang mengisi sendiri soal-soal yang diberikan oleh gurunya. Ibu E misalnya ia memiliki anak bernama B (16 tahun), usia SMA, ibu E tak jarang ikut serta mengisi dan mendatangkan guru les dengan tugas khusus yaitu mengerjakan tugas-tugas anaknya yang dikirannya tidak mampu. Ini bukan masalah biasa tapi perlu diteliti lebih lanjut dan dicarikan akar masalah dan solusinya demi pendidikan yang lebih baik. Dan kasus di atas hanya bagian kecil dari banyak kasus yang berkaitan dengan minimnya kadar pendidikan kemandirian pada anak. Sepertinya orang tua berusaha membuat anak-anak nyaman anak-anaknya dan menghindarkan persoalan kehidupan padahal sejatinya anak bisa belajar dari persoalan-persoalan

\section{Pentingnya Peran Orang Tua Sebagai Pendidik Utama}

Upaya untuk menyadarkan kembali peran dan tanggungjawab orang tua dalam mendidik anak agar mandiri secara berkelanjutan perlu digaungkan lagi dalam pendidikan. Hal tersebut tentu akan berperan penting bagi anak pada kehidupan mendatang. Sebab untuk menghadapi tantangan globalisasi diperlukan pembelajar mandiri. Orang tua dituntut untuk belajar kembali (re learn) beberapa pendekatan dalam pendidikan kemandirian anak seperti metode self directed learning yang sedemikian rupa diadaptasikan dengan kondisi rumah, lingkungan rumah dan penugasan dari guru di sekolah. Di sini orang tua menjadi role model dari pembelajaran kemandirian itu sendiri tentu dengan memanfaatkan berbagai fasilitas pembantu seperti browsing di google, yotube, facebook dan media lain yang berterbaran di internet.

Cara untuk penyadaran peran tersebut bisa dilakukan dengan dimulai dari: pertama, memahami kembali falsafah pendidikan yang bertujuan untuk memaksimalkan seluruh potensi manusia itu sendiri bukan melulu menekankan pada kognisi anak. Kedua, mereview kembali pembelajaran yang telah diterima anak selama ini; apa saja yang terlewatkan, 
perlu disempurnakan, diperbaiki bahkan disesuaikan lagi dengan konteks melalui pendekatan komunikatif, membuat proyek kelurga bersama-sama, dan memikirkan cara terbaik untuk menyelesaikan suatu persoalan bersama-sama. Ketiga, membuka pikiran pada hal-hal yang baru dan informasi terkini terkait dengan perkembangan pendidikan anak. Di sini orang tua dituntut kembali untuk membaca dan membuka pikiran pada saluran-saluran pendidikan baik lama maupun baru, memperbanyak referensi terkait dengan itu, tergabung dalam grup atau komunitas yang concern berkenaan dengan pendidikan kemandirian anak. Untuk itu saya menambahkan rekomendasi beberapa buku yang bagus untuk dibaca diantaranya buku karangan friedman, The World is Flat: a Brief History of the Twenty-First Century beliau mengatakan dalam bukunya: today, the most important skill is learning how to learn. Buku future shock oleh Alvin tovler, beliau yang mengatakan bahwa The illiterate of the 21st century will not be those who cannot read and write, but those who cannot learn, unlearn, and relearn, atau beberapa buku berbahasa inggris lainnya misal Selfdirected learning: A guide for learners and teacher oleh Knowles, buku Free to Learn: Why Unleashing the Instinct to Play Will Make Our Children Happier, More Self-Reliant, and Better Students for Life, oleh Peter Gray, atau buku (tersedia ebook yang bisa didownload Self-Directed Learning for the 21st Century: Implications for Higher Education, editor Elsa Mentz dkk. Buku berbahasa indonesia juga tak kalah menariknya untuk dipelajari misalnya Memulihkan Sekolah Memulihkan Manusia Oleh Haidar Bagir, Fitrah Based Education Oleh Harry Santosa, Sokola Rimba oleh Butet Manurung, Kasmaran Berilmu Pengetahuan Oleh Iwan Pranoto. Buku buku tersebut ada yang serius dan ada yang bertuliskan populer yang enak dan mudah dibaca. 


\section{Mengambil Peran dan Tanggung Jawab di Rumah dan di Masyarakat}

Ini merupakan rumusan penting dari pendidikan kemandirian, yaitu mengambil peran. Latihan latihan ini perlu dijadikan pendidika harian di rumah dimulai dari tatanan beribadah dan bermuamalah (berhubungan dengan sosialita). Konsepsi menarik dalam hal ini bisa kita dapatkan pada konsep akil baligh dalam Islam, yang berbeda secara definisi terkait dengan definisi anak anak dalam undang undang perlindungan anak. Kita bisa membandingkan pada Pasal 1 angka 1 Undang-Undang 23 Tahun 2002 tentang perlindungan anak yang mendefinisikan bahwa yang dimaksud dengan anak adalah seseorang yang belum berusia 18 (delapan belas) tahun, termasuk anak yang masih dalam kandungan. Sementara itu anak dalam Islam konsep anak dibatasi dengan pengertian belum munculnya ciri ciri pubertas yang ditandai oleh haid pada wanita, dan telah keluar sperma bagi laki laki. Penekanan definisinya lebih kepada memikul tanggung jawab (taklif) dan jika telah memiliki ciri kedewasaan apa yang disebut masih anak-anak oleh kita ternyata bukan anak-anak lagi. Jadi ini bisa jadi kurang atau jauh lebih awal daripada 18 tahun menurut hukum positif. Artinya sedemikian rupa dalam pendidikan Islam prioritas prioritas penyokong kehidupan awal anak mandiri menjadi sorotan penting. Sorotan tersebut berupa: bagaimana ia bisa mandiri beribadah, berekonomi, bahkan memberikan andil dalam kehidupan bermasyarakat, sebab hidupnya adalah tanggung jawabnya sendiri, segala perbuatannya akan memiliki konsekuensi yang akan ditanggungnya sendiri. Oleh sebab itu, jika kita bertolak dari konsep ini akan ada banyak pembelajaran yang akan dieleminasi dari pendidikan anak kita. Pembelajaran yang kurang penting dan tak berkaitan dengan kehidupannya diberikan ruang tunggu dan tidak menjad prioritas.

Dalam pendidikan Islam misalnya muncul suatu konsep yang menyatakan bahwa ilmu yang paling utama untuk 
dipelajari ialah ilmu haal, yakni ilmu yang bersentuhan langsung dengan kehidupan anak. Mengacu pada hal itu, kurikulum pembelajaran akan lebih sederhana dan mudah dilaksanakan karena sifatnya yang urgent, priority based dan berbasis keluarga. Dikatakan berbasis keluarga sebab praksis seperti akan lebih mudah dilaksanakan pada sekup keluarga lantaran sifatnya yang lebih fleksibel dan dinamis. Lembaga pendidikan kurang begitu berdaya dan lambat bergerak dalam menyerap perkembangan karena sistemnya besar dan berdimensi luas karena terikat dengan subsistem lain seperti kebijakan pendidikan, politik pendidikan dan penyesuaianpenyesuaian lainnya.

\section{Penutup}

Ala kulli haal, kedepan lembaga pendidikan akan kembali lagi pada fitrahnya yang awal yaitu keluarga. Lainnya, pendidikan akan bertumpu pada kolaborasi, grup grup dan komunitas-komunitas inklusif. Di masa depan anak akan memilih pembelajaran yang hanya sesuai dengan minatnya saja sebab pendidikan tradisional dengan sistem kelas, guru terpusat, digantikan dengan sistem yang fleksibel, berbasis proyek dengan kesamaan minat, murah, tak tersekat oleh kelas dan tentu saja mengglobal. Oleh sebab itu pendidikan keluarga sebagai basis pendidikan awal memiliki kesempatan besar untuk memberikan ruang pada anak untuk mengeksplorasi, membantu dan memberikan arahan-arahan yang menekankan arti penting pendidikan kemandirian. Karenanya, pendidikan kemandirian anak menjadi teramat penting terlebih di saat pandemi covid 19 ini. 


\section{Daftar pustaka}

Al Zarnuji, Burhan al-Islam. Ta'lim al Muta'allim (dalam Syarh Syaikh Ibrahim Bin Isma'il), Semarang: PT. Toha putra, t.th

Dryden, Gordon \& Vos, Jeannette. 2000. Revolusi Cara Belajar, Bandung, Mizan Media Utama.

Knowles, Malcolin, 1974, New York, Self-directed learning: A guide for learners and teacher, cambridge. 


\title{
KOMUNIKASI ORANG TUA DAN ANAK SELAMA PEMBELAJARAN ONLINE
}

\author{
Teddy Dyatmika, M.I.Kom ${ }^{28}$ \\ (IAIN Pekalongan)
}

\begin{abstract}
"Komunikasi antara anak dengan orang tua, komunikasi antara sekolah dengan anak didik, dan juga komunikasi antara sekolah dengan orang tua. Semuanya menjadi satu kesatuan yang tidak terpisahkan agar proses pembelajaran virtual dapat berlangsung dengan optimal"
\end{abstract}

Dada tanggal 11 Februari 2020 WHO merilis nama covidWuhan. Coronavirus Disease of 2019 atau Covid-19 pertama kali ditemukan di Wuhan, China (Saputra, 2021). Efek kerambol dari kehadiran virus ini menyentuh berbagai macam bidang. Mulai dari bidang perekonomian, bidang kesehatan, bidang politik, bidang komunikasi bahkan sampai bidang pendidikan. Tulisan ini akan lebih menekankan pada perubahan yang terjadi pada bidang komunikasi dan bidang pendidikan. Bidang komunikasi dan pendidikan ini saling terkait satu dengan yang lain. Pola komunikasi yang terjadi pada saat pandemi ini mengalami perubahan yang cukup signifikan. Komunikasi secara tatap muka sudah mengalami penurunan secara signifikan. Selain dikarenakan harus melakukan social distancing, kehadiran teknologi komunikasi juga mengubah pola komunikasi yang terjadi di masyarakat.

${ }^{28}$ Penulis lahir di Tegal 13 Februari 1987, penulis menyelesaikan pendidikan S1 di IKIP PGRI Semarang dan S2 di Universitas Diponegoro Semarang. Saat ini penulis menjadi dosen di Program Studi Komunikasi dan Penyiaran Islam, Fakultas Ushuluddin, Adab, dan Dakwah, IAIN Pekalongan 
Data dari we are social menunjukkan bahwa pengguna internet mengalami peningkatan yang cukup signifikan per Januari 2021. Mobil Connection mengalami peningkatan jumlah 4 juta pengguna atau naik 1,2\% dari Januari 2020. Internet User mengalami peningkatan 27 Juta pengguna atau naik 15,5\% dari Januari 2020. Active Social Media User mengalami peningkatan 10 Juta pengguna atau naik 6,3\% dibandingkan Januari 2020 (Social, 2021). Pada bidang pendidikan juga mengalami perubahan yang cukup signifikan, tidak diperbolehkannya pertemuan tatap muka dalam proses pembelajaran membuat proses pembelajaran berjalan secara virtual. Dosen, Guru, Mahasiswa, Siswa bahkan Orang Tua siswa dipaksa harus paham dan tidak gagap dengan dunia digital. Segala proses pembelajaran dilakukan melalui media yang terkoneksi dengan internet atau dalam dunia komunikasi dinamakan dengan new media. Mereka dipaksa belajar secara otodidak tanpa adanya pelatihan terlebih dahulu karena memang kehadiran pandemi Covid-19 tidak direncanakan sebelumnya.

Berbagai macam media pembelajaran digunakan mulai dari aplikasi yang sederhana seperti whatsapps dan google classroom sampai aplikasi meeting secara virtual seperti zoom, google meet dan microsoft teams. Bagi pengajar dan peserta didik yang paham akan dunia digital tentu bukan menjadi halangan yang berarti. Hal tersebut dikarenakan banyak sekali video cara penggunaan aplikasi tersebut yang bisa ditonton secara gratis untuk dapat dipelajari. Permasalahan muncul bagi anak-anak yang dipaksa menggunakan media internet atau virtual dalam melakukan proses pembelajaran. Butuh waktu untuk mengajarkan mereka bagaimana menggunakan media pembelajaran virtual. Selain itu anak juga perlu diberikan pendampingan saat proses pembelajaran berlangsung. Permasalahan ini menjadi semakin rumit apabila kedua orang tua anak tersebut tidak bisa mendampingi anaknya dalam proses pembelajaran yang berjalan secara virtual ini. 
Orang tua juga dituntut agar bisa menggunakan media pembelajaran virtual ini sebelum mereka mengajarkan kepada anaknya. Peran ganda orang tua ini jelas menjadikan pola komunikasi yang terjadi antara orang tua dengan anak mengalami perubahan. Ketidak sabaran dan ketidakmampuan orang tua dalam mengajari dan mendampingi anak menjadikan komunikasi yang terjalin menjadi negatif. Orang tua terkadang sering melampiaskan kemarahan kepada anak mana kala anak tidak bisa mengikuti proses pembelajaran atau tidak tahu tugas apa yang diberikan oleh sekolahnya. Kemarahan ini muncul sebagai efek kelelahan orang tua yang sudah seharian bekerja. Kelelahan semakin menjadi bertambah saat anaknya tidak melakukan proses belajar dengan baik dan banyak tugas yang diberikan sekolah yang belum terselesaikan. Tentu secara psikis hal tersebut sangat tidak baik bagi tumbuh kembang sang anak. Seorang anak juga sudah merasa lelah dan jenuh dengan proses pembelajaran virtual dan harus ditambah mendapatkan komunikasi yang negatif dari orang tua mereka.

Dari penelitian sebelumnya yang sudah dilakukan menunjukkan bahwa dukungan keluarga dalam proses pembelajaran sangat penting. Melalui dukungan yang diberikan keluarga membuat anak menjadi lebih aktif dan semangat dalam melakukan proses pembelajaran (Bakhri et al., 2020). Senada dengan yang dengan penelitian yang dilakukan oleh (Dinda Pertiwi et al., 2021), bahwa peran orang tua sangat penting sebagai pendamping anak dalam belajar dan juga dalam memotivasi anak dalam menjalankan proses pembelajaran. Peran sekolah dalam melakukan komunikasi dengan orang tua atau orang tua yang aktif dengan melakukan komunikasi dengan pihak sekolah juga menjadi sesuatu yang penting. Orang tua tidak bisa hanya mengandalkan kepada anak saja apa yang tadi disampaikan oleh guru mereka. Melalui komunikasi yang aktif dari orang tua kepada sekolah menjadikan orang tua menjadi tahu apa 
yang hendak dicapai oleh sekolah melalui pmbelajaran online ini. Setelah tahu orang tua akan menjadi lebih mudah dalam melakukan pendampingan kepada anak selama proses pembelajaran virtual berlangsung selama pandemi ini (Pertiwi et al., 2021). Lingkungan belajar yang kondusif juga sangat penting bagi anak selama menjalankan pembelajaran secara online (Kurniati et al., 2020).

Komunikasi menjadi kunci penting dalam proses pembelajaran anak secara virtual saat pandemi covid-19 ini. Komunikasi antara anak dengan orang tua, komunikasi antara sekolah dengan anak didik, dan juga komunikasi antara sekolah dengan orang tua. Semuanya menjadi satu kesatuan yang tidak terpisahkan agar proses pembelajaran virtual dapat berlangsung dengan optimal. Kesabaran guru dalam mengajar dan kesebaran orang tua dalam melakukan pendampingan selama proses pembelajaran sangat penting dilakukan. Bagi orang tua yang harus bekerja meninggalkan anak selama proses pembelajaran online berlangsung harus ekstra sabar dan ekstra aktif. Sabar saat harus mendampingi anak mengerjakan tugas dimalam hari dan aktif melakukan komunikasi dengan pihak sekolah materi apa saja yang diberikan hari ini dan tugas apa saja yang harus dikerjakan oleh seorang anak. Membiarkan anak sendirian menghadapi pebelajaran online tentu bukanlah hal yang bijak. Apalagi anak tersebut masih berada pada tingkat Sekolah Dasar. Mereka tentu membutuhkan perhatian, komunikasi yang baik dan dukungan yang optimal. Jangan membuat psikis anak menjadi tambah turun karena komunikasi yang dilakukan oleh orang tua kepada anak lebih pada komunikasi negatif dengan nada kasar dan nada tinggi. Anak sudah lelah dengan pembelajaran online maka jangan tambah kelelahan mereka dengan komunikasi negatif yang dilakukan oleh orang tua. 


\section{Daftar Pustaka}

Bakhri, S., Dyatmika, T., \& Kamal, M. R. (2020). Pengaruh Kemampuan Menggunakan Teknologi Komunikasi, Sosialisasi Media Pembelajaran Online, Dukungan Keluarga dan Pengajar Terhadap Keaktifan Mahasiswa di Masa Pandemi Covid-19. MEDIAKITA, 4(1). https://doi.org/10.30762/mediakita.v4i1.2445

Dinda Pertiwi, S. S., Sekar Ayu Aisyah, P., Zidni Ilma, N., \& Yuwono. (2021). Parenting of Parents Working from Home During the Pandemic: Pengasuhan Anak Pada Orang Tua yang Bekerja dari Rumah Saat Pandemi. Proceding of Inter-Islamic University Conference on Psychology, 1(1), 1-6. https://press.umsida.ac.id/index.php/iiucp/article/vie $\mathrm{w} / 606 / 428$ ?download=pdf

Kurniati, E., Nur Alfaeni, D. K., \& Andriani, F. (2020). Analisis Peran Orang Tua dalam Mendampingi Anak di Masa Pandemi Covid-19. Jurnal Obsesi : Jurnal Pendidikan Anak Usia Dini, 5(1), 241. https://doi.org/10.31004/obsesi.v5i1.541

Pertiwi, L. K., Febiyanti, A., \& Rachmawati, Y. (2021). Keterlibatan Orang Tua Terhadap Pembelajaran Daring Anak Usia Dini Pada Masa Pandemi Covid-19. Cakrawala Dini: Jurnal Pendidikan Anak Usia Dini, 12(Vol 12, No 1 (2021): Mei 2021), 19-30. https://ejournal.upi.edu/index.php/cakrawaladini/arti cle/view/26702/14864

Saputra, A. (2021). Apa Kepanjangan dari COVID-19? SelukBeluk Penamaan Wabah yang Tengah Menggemparkan Dunia.

https://aido.id/health-articles/apakepanjangan-dari-covid-19-seluk-beluk-penamaanwabah-yang-tengah-menggemparkan-dunia/detail

Social, W. A. (2021). we are social, Indonesia digital 2019. 


\title{
KORELASI PROCESS ORIENTED MANAGEMENT DENGAN SDM UNGGUL
}

\author{
Yudi Haryadi S.E.,M.M ${ }^{29}$ \\ (Universitas Muhammadiyah Bandung)
}

"Process Oriented Management pada peningkatan SDM unggul merupakan proses bagaimana organisasi atau sebuah perusahaan mencari menempatkan orang dengan kualifikasi yang tepat untuk setiap bagian yang ada di organisasi atau

perusahaan, sejak dari perekrutan, mendidik dan mempertahankan SDM, sehingga sesuai dengan goals yang ingin dicapai suatu organisasi atau perusahaan"

\begin{abstract}
A pabila dalam melakukan suatu tindakan selalu Aberorientasi hasil semata, Kita akan sangat mudah mendapatkan kekecewaan karena hasilnya tidak selalu seperti apa yang kita harapkan, untuk itu mulai saat ini berorientasilah pada proses karena yakinlah bahwa hasil itu akan mengikuti prosesnya, atau istilah populernya "Proses tidak akan pernah menghianati hasil".
\end{abstract}

Seandainya masih banyak orang yang masih mementingkan hasil daripada proses, maka cenderung orang akan menghalalkan segala cara asalkan mendapatkan hasil yang baik tidak peduli bagaimanapun caranya. Contohnya adalah akibat dari mementingkan hasil banyak orang yang memperoleh gelar sarjana dengan cara pintas, hanya ingin

${ }^{29}$ Penulis adalah Dosen ekonomi syariah Universitas Muhammadiyah Bandung, Lahir di Bandung 19 Juni 1975, menyelesaikan study S1 di Sekolah Tinggi Ilmu Ekonomi Kridatama Bandung dan menyelesaikan study S2nya di IKOPIN Bandung, Penulis juga sebagai Founder itQan Group yang didirikan tahun 2007 (Sekolah PreSchool, SD-SMP IT, Koperasi Syariah, Lembaga Sosial dan mengajar di beberapa PT), Praktisi Pendidikan dan Keuangan Syariah 
mendapatkan ijazah dan pengakuan saja dengan tidak mengikuti prosedur seharusnya yaitu melalui jenjang pendidikan, maka wajar saja orang yang mendapatkan dengan cara 'instant' tidak akan mencerminkan kualitas yang seharusnya, karena disebabkan gelar atau ijazahnya diperoleh dengan cara "membeli". Untuk itu marilah kita utamakan proses, serumit apapun itu, kita akan merasa puas dengan ikhtiar yang di lakukan karena hasil dari kerja keras dengan mengerahkan semua sumber daya yang kita miliki, berkorban tenaga, waktu dan tidak sedikit biaya serta pengorbanan lainnya yang tidak terhitung nilainya. Yakinlah kalau prosesnya bagus maka bisa dipastikan hasilnya juga akan bagus.

Dalam membangun Sumber Daya Manusia yang unggul tidak bisa dilakukan dengan cara instant yang hanya berorientasi pada hasil, kita harus memiliki prinsip kualitas itu lebih penting dari pada kuantitas. Perubahan itu hanya akan terjadi karena dilakukan oleh orang-orang yang memiliki kualitas unggul kalaupun sedikit daripada banyak orang tapi tidak berkualitas, Rumusan maslah dari tulisan ini adalah apakah yang dimaksud dengan Manajemen Berorientasi pada Proses dan apakah yang dimaksud dengan SDM unggul.

\section{A. Manajemen Berorientasi Pada Proses}

Manajemen berorientasi pada proses (process oriented) yang berarti bahwa manajemen membutuhkan sumber daya manusia, pengetahuan, dan keterampilan agar aktivitas menjadi lebih efektif atau dapat menghasilkan tindakan dalam mencapai kesuksesan. Oleh sebab itu, tidak akan ada organisasi yang akan sukses apabila tidak menggunakan manajemen yang baik. (Torang, 2013: 165).

Berdasarkan pengertian diatas, dapat disimpulkan bahwa yang dimaksud dengan Manajemen adalah ilmu mengatur proses untuk mencapai tujuan yang telah ditetapkan sebelumnya guna mencapai hasil yang sesuai, yang tentunya 
sangat didukung oleh SDM yang handal, atau dengan kata lain berkualitas.

Demikian pula untuk mendapatkan Sumber Daya Manusia yang unggul dalam bidang apapun tidak bisa dilakukan secara instant tapi butuh proses yang terus menerus. George R. Terry,1958 dalam bukunya Principles of Management (Sukarna, 2011: 10) membagi empat fungsi dasar manajemen, yaitu Planning (Perencanaan), Organizing (Pengorganisasian), Actuating (Pelaksanaan) dan Controlling (Pengawasan). Keempat fungsi manajemen ini disingkat dengan POAC.

\section{B. Sumber Daya Manusia Unggul}

Sumber daya manusia adalah manusia yang bekerja dilingkungan suatu organisasi (sering disebut juga personil, tenaga kerja, pegawai atau karyawan).

Sumber daya manusia adalah potensi yang merupakan asset dan berfungsi sebagai modal (non material/ non financial) di dalam organisasi, yang dapat mewujudkan menjadi potensi nyata secara fisik dan non fisik dalam mewujudkan eksistensi organisasi (Nawawi,2000)

Pengertian unggul dalam hal ini adalah manusia/individu yang profesional dalam arti bertanggung jawab, jujur, amanah, dan berorientasi pada pekerjaan.. Konsep manusia unggul juga di paparkan oleh Gubernur Provinsi Jabar, menurut Kang Emil, dalam pandangan dia, terdapat empai nilai sumber daya manusia unggul yakni religius (iman), cerdas (ilmu), berkarakter (akhlak), fisik dan mentalnya (sehat).Manusia unggul tidak bisa didapatkan dengan cara yang biasa-biasa saja. Mendapatkan sumber daya manusia unggul didapatkan dari 2 cara :

1. Latar belakang seseorang yang sebelumnya memang sudah berada dilingkungan mendukung atau kondusif terhadap perilaku-perilaku unggul. 
2. Melalui Proses yang harus dilalui dengan system yang dibuat oleh perusahaan atau Lembaga untuk menciptakan atau mendapatkan sumber daya manusia yang unggul dari mulai perekrutan, mendidik (Personnel Development) dan mempertahankan SDMnya.

Membangun SDM berarti membangun karakter kemanusiaan para pemimpin negeri ini di masa mendatang, harus memiliki karakter yang unggul, karakter Indonesia, karakter Pancasila. Sehingga diharapkan 15 tahun ke depan Indonesia benar-benar memiliki pemimpin dan tokoh yang berkarakter hebat, dan bangsa ini pun menjadi bangsa yang berkarakter hebat pula.

Manajemen sumber daya manusia bisa didefinisikan sebagai proses serta upaya untuk merekrut, mengembangkan, memotivasi, serta mengevaluasi keseluruhan sumber daya manusia yang diperlukan organisasi atau perusahaan dalam pencapaian tujuannya, memperoleh SDM yang tepat (the man on the right place).

Peran Manajemen sumber daya manusia ini sangat vital bagi mewujudkan SDM yang produktif, efektif dan efesien. Menurut Peter F. Drucker, efektif disini didefinisikan sebagai tenaga kerja yang mampu melakukan pekerjaan dengan benar (doing the right things). Sedangkan efesien disini dimaksudkan sebagai tenaga kerja yang mampu untuk melakukan sesuatu dengan benar ( doing things right). Kunci pokok dari manajemen SDM adalah how to find or get the best person, and how to maintain it. Bagaimana kita mendapatkan orang yang tepat untuk pekerjaan yang tersedia dalam organisasi atau perusahaan kita, dan bagaimana kita memelihara dan mempertahankannya.

Yang dimaksud dengan proses manajemen SDM adalah segala proses yang berkaitan dengan upaya yang dilakukan dari mulai merencanakan, mendapatkan, membina dan mengembangkan hingga memelihara orang yang tepat tersebut pada posisi dan kualifikasi tertentu. Seperti yang di 
isyatkan Alloh SWT dalam Al Qur'an Surat Ara'du ayat 11 yang artinya "Sesungguhnya Alloh tidak akan merubah nasib suatu kaum sehingga mereka merubah kondisi dirinya sendiri ". Artinya adalah bahwa bila ingin memperoleh SDM yang unggul harus ada effort yang besar tidak bisa biasa-biasa saja.

Secara garis besar proses manajemen SDM dibagi kedalam 5 bagian fungsi utama yang terdiri dari :

1. Human Resource Planning, merencanakan kebutuhan dan pemanfaatan SDM bagi perusahaan.

2. Personnel Procurement, mencari dan mendapatkan SDM termasuk didalamnya rekrutmen, seleksi dan penempatan serta kontrak tenaga kerja.

3. Personnel Development, mengembangkan SDM unggul termasuk didalamnya program orientasi tenaga kerja, Pendidikan dan pelatihan yang tepat.

4. Personnel Maintenance, memelihara SDM, termasuk pemberian penghargaan, intensif, jaminan Kesehatan dan keselamatan tenaga kerja, dan lain sebagainya.

5. Personnel Utilization, memanfaatkan dan mengoptimalkan SDM, termasuk didalmnya promosi, demosi, transfer dan juga separasi.

\section{Kesimpulan}

Process Oriented Management pada peningkatan SDM unggul merupakan proses bagaimana organisasi atau sebuah perusahaan mencari menempatkan orang dengan kualifikasi yang tepat untuk setiap bagian yang ada di organisasi atau perusahaan, sejak dari perekrutan, mendidik dan mempertahankan SDM, sehingga sesuai dengan goals yang ingin dicapai suatu organisasi atau perusahaan.

Secara garis besar proses manajemen SDM terdiri dari, Human Resource Planning, Personal Procurement, Personel Development, Personnel Maintenance, dan Personnel Utilization. 


\section{Daftar Pustaka}

Sukarna. 2011. Dasar-Dasar Manajemen. Bandung: CV. Mandar Maju..

Torang, Syamsir. 2013. Organisasi dan Manajemen (Perilaku, Struktur, Budaya \& Perubahan Organisasi. Bandung: Alfabeta

George, R. Terry, dan Leslie W Rul. 1999. Dasar-dasar Manajemen. Jakarta: Bumi Aksara.

Erni Tisnawati Sule, dan Kurniawan Saefulloh. 2005. Pengantar Manajemen.Jakarta: Kencana Prenada Media 


\title{
PERSPEKTIF PENDIDIK DALAM MENANAMKAN PENDIDIKAN KARAKTER DAN MENGATASI PROBLEMATIKA PEMUDA
}

\author{
Heri Budianto, M.A.P. ${ }^{30}$ \\ (MAN Sumenep)
}

\begin{abstract}
"Pendidik akan menjadi garda terdepan mengukir arah jalannya suatu bangsa dengan pembentukan karakter kaum muda. Dengan sebuah langkah optimis memberikan realita penanaman pendidikan karakter pada anak"
\end{abstract}

( $R$ erikan aku sepuluh pemuda maka akan kugoncangkan D dunia". Sepenggal pernyataan tokoh kebanggan bangsa Indonesia (Ir. Soekarno) mengguncangkan seluruh dunia. Mayoritas rakyat negeri ini tertancap pernyaaan yang mudah mengobarkan semangat kalangan pemuda. Tidak dapat diragukan lagi hembusan pengobar semangat Ir. Sukarno menjadi branding tersendiri di setiap lini kehidupan bangsa ini. Generasi muda mengemban amanah ekspektasi para pendiri bangsa untuk membawa arah kehidupan negeri pada arah yang lebih baik. Kreasi lompatan level tinggi dalam implementasi pengejawantahan proses kehidupan diri pribadi dan keseluruhan sendi kehidupan bangsa dan negara. Sulut semangat Ir. Sukarno berbaanding lurus dengan pragmatis kenyataan di kehidupan nyata. Tidak bisa dielakkan di setiap tahapan generasi akan ditemui figur muda kreatif, inspiratif, dan solutif.

${ }^{30}$ Heri Budianto, M.A.P. merupakan seorang pendidik Pendidikan Pancasila dan Kewarganegaraan (PPKn) di MAN Sumenep. Ia pernah menjadi dosen tidak tetap salah satu kampus ternama di Malang, Wakamad Kurikulum MA. Nurul Hikmah, Ketua MGMP PPKn Kab. Sumenep, Ketua MGMP Dasuk, Ambunten, Pasongsongan Kab. Sumenep. 
Kalangan pemuda melekat seluruh potensi melekat dalam diri, bakat dan minat yang dimiliki akan selalu menjadi fokus perhatian untuk dapat dieksplorasi. Narasi tentang pemuda dinamis bergerak menuju kehidupan yang mampu mengubah dari mendasar sampai tatanan tertinggi. Klub sepakbola besar Eropa menerapkan pembinaan pemain muda yang disiapkan untuk menggenggam prestasi tertinggi di kancah persepakbolaan internasional. Kreasi pemain muda Manchester United Marcur Rashford dan Jesse Lingard menjadi roh permainan indah menyerang tim. Harapan meraih gelar prestise dibebankan di pundak mereka dalam meraih prestasi puncak di semua level kompetisi. Berkaca pada sisi persepakbolaan dunia, pemberian porsi kesempatan pada kalangan pemuda menjadi atensi tersendiri yang memerlukan perhatian serius. Perlu dipahami bersama bahwa semua ini bukan sebuah wacana yang hanya bergelayut di alam imajinasi. Pembinaan dan arahan yang tepat sasaran dari proses kreasi kaum muda membutuhkan perhatian serius sehingga prestasi bisa diraih. Kondisi seperti ini sedang kita alami bersama dan membutuhkan treatment yang lebih sistematis. Dari waktu ke waktu kondisi terus mengalami pembaharuan yang menuntut selalu berinovasi menjawab tantangan setiap perubahan yang terjadi. Dalam saat tertentu, sisi kurang baik sangat dimungkinkan muncul, kurangnya agar bersedia berpikir kritis, sesuatu yang cepat saji seringkali menjadi menu utama tanpa berproses lebih lanjut, miris penurunan tingkat adab pada diri pemuda terjadi berulang. Perlu disadari fakta yang tersebut pada penurunan tata krama moral pemuda perlu ada penggalian metode untuk menjadi sebuah solusi. Barang kali perlu kiranya penanganan yang cepat segera diambil untuk mengatasi kondisi tersebut agar bangsa ini tidak hanya menjadi sebatas cerita. Maka dari itu, segera aksi nyata semua lini keluarga, sekolah, dan masyarakat bersatu menyikapi hal tersebut. Peran pemuda memerlukan treatment keluarga, sekolah, dan masyarakat dalam 
memantau perkembangan kematangan diri pemuda dalam menjawab tantangan zaman.

Fungsi keluarga memberikan pengaruh yang cukup signifikan untuk membentuk kematangan karakter kalangan pemuda. Ruang lingkup terdekat seperti keluarga membawa efek sangat baik dalam penanaman pendidikan karakter yang baik pada diri anak. Di dalam keluarga, ada penanaman norma-norma kesopanan dan kesusilaan yang sepatutnya berlaku di tengah kehidupan masyarakat. Masa-masa itu bisa ditemukan ketika seorang ibu mengandung bayi, memegang perut serta menyampaikan harapan dan doa agar kelak anak yang dikandung berguna bagi masyarakat, bangsa, dan negara. Ekspektasi orang tua terhadap anak di masa depan mampu memberikan tuntunan pijakan dalam bertutur, bersikap manjadi manusia Indonesia seutuhnya yang berkarakter. Fungsi sekolah juga memegang peranan penting dalam membentuk karakter pemuda. Banyak waktu yang disediakan anak dan kaum muda dalam menuntut ilmu di bangku sekolah atau perpendidikan tinggi. Di lingkungan sekolah, terdapat sebuah proses pembelajaran transfer ilmu, serta pembelajaran sosiologis interaksi antara satu dengan yang lainnya dalam sebuah komunitas institusi pendidikan. Saat seperti itu, mampu mentransfer secara berkelanjutan institusi pendidikan menjadi ruang lingkup masyarakat. Maka dari itu, peran penting seorang pendidik sangat signifikan sebagai komposer pembentukan karakter kaum muda. Dikarenakan pendidik juga orang tua kedua setelah orang tua kandung memiliki fungsi sebagai pengasah ketajaman ujung tombak harapan bangsa yang akan dibebankan di pundak kaum muda. Tugas pendidik tidak hanya mengajar, tapi juga mampu mendidik, membentuk jati diri kaum muda yang diharapkan berhasil menjadi generasi yang berjaya di dunia dan akhirat. Hal ini, mampu mentransformasi pemacu semangat pendidik untuk tidak kenal lelah dalam menjalankan tugas pokok dan fungsinya turut menentukan arah perjalanan suatu bangsa menuju 
pada peradaban maju melalui pembentukan pendidikan karakter kaum muda. Pengabdian dan pengorbanan dalam sebuah loyalitas tanpa batas membimbing anak didik tumbuh berkembang menjadi pemuda harapan bangsa merealisasikan cita-cita para pendiri bangsa.

Fungsi berikutnya yang juga memegang peranan penting pembentukan karakter kaum muda yaitu di kehidupan masyarakat. Dalam hal ini, masyarakat secara holistik universal yang berada di sekitar para pemuda. Situasi ini dilatar belakangi semakin mudah berkembang informasi dan komunikasi yang terjalin antara orang satu dengan orang lain di berbagai belahan dunia. Maka dari itu, dibutuhkan instrumen yang mampu memberikan keseimbangan konsistensi pengmabilan tindakan yang benar. Instrumen yang dibutuhkan antara lain, internalisasi norma-norma karakter jati diri bangsa menuju pada sebuah peradaban yang maju dan bermartabat. Deras arus perubahan di setiap pergantian waktu tak akan mampu mengubah karakter identitas suatu bangsa yang telah dibentuk secara tepat, terarah, dan berkelanjutan.

Trisula pendidikan karakter melalui keluarga, sekolah, dan masyarakat menjadi dasar pondasi kuat pembentukan identitas yang tak mudah tergerus zaman. Maka sepatutnya merencanakan pembekalan sumber daya manusia dengan segala instrumen yang memadai seperti tatanan adab, norma, nilai luhur budi pekerti dan tata krama sebagai jati diri karakter bangsa. Modal kepribadian tersebut diharapkan mampu mereinkarnasi pembentukan karakter yang linier dengan harapan dan cita-cita pendiri bangsa ini. Langkah awal yang segera diambil ialah penanaman nilai luhur bangsa, falsafah, dan ideologi sebagai penentu arah bangsa menuju pada kehidupan kebangsaan tanpa mengubah jati diri bangsa yang berkarakter. Upaya tersebut akan mampu memberi dampak baik dalam diri kaum muda dalam menentukan sikap. Peran pendidik mempunyai efek melekat dalam pendidikan karakter yang sesuai dengan cita-cita 
bangsa ini. Pendidik akan berproses membimbing, mengarahkan,dan mendidik secara detail agar pembentukan karakter kaum muda dapat diaplikasikan. Upaya konkrit yang dilakukan pendidik memerlukan dukungan semua pihak dengan harapan apa yang sudah dilaksanakan oleh pendidik tidak hanya sekedar menjadi cerita sejarah saja tapi juga mampu meninggalkan jejak dan pijakan dalam langkah selanjutnya menuju bangsa yang beradab dan bermartabat.

Pendidik akan menjadi garda terdepan mengukir arah jalannya suatu bangsa dengan pembentukan karakter kaum muda. Dengan sebuah langkah optimis memberikan realita penanaman pendidikan karakter pada anak. Dengan jalan pendidikan anak selama masa di kandungan, situasi ini dilatar belakangi semakin mundurnya karakter yang dimiliki oleh kaum muda terlebih pada sisi profetik. Salah satu peran keluarga akan mampu mereduksi problematika pada kaum muda menyangkut lemahnya suatu karakter. Keluarga diyakini mampu menjadi salah satu trisula pendidikan dalam penanaman pendidikan karakter pada anak. Sejak anak dalam kandungan ibu akan selalu memegang perut dan memberikan sentuhan emosi dalam internalisasi pembentukan karakter seotang anak. Dalam masa kehamilan ibu selalu aktif memantau tumbuh kembang anak agar sehat secara lahir dan batin. Melantunkan ayat suci Al-Quran di setiap saat setiap waktu untuk pendidikan skala kecil ketika anak dalam kandungan mampu membawa efek positif dalam perkembangan buah hati.

Alfin Faradian menyampaikan pendapatnya tentang perkembangan kaum pemuda di era digital saat ini. Dengan gagasan yang dimiliki dirinci secara akurat dan mendalam mempersiapkan pemuda dalam bersikap dan bertindak di era digital. Kaum muda milenial ini bergelar generasi $\mathrm{Z}$ bisa beradaptasi dalam segala perubahan dan tantangan zaman. Maka, tak perlu lagi harus bertemu langsung dalam berinteraksi, namun cukup dengan memanfaatkan modernisasi teknologi kaum muda dapat melakukan segala 
aktifitas mereka dengan baik. Informasi dan komunikasi di era digital akan menentukan sikap dan tindakan yang diambil kaum muda. Maka dari itu, penting akan sebuah penanaman nilai-nilai budaya karakater bangsa. Situasi seperti demikian memerlukan perhatian khusus terutama dari para orang tua dan pendidik dalam memberikan metode pendidikan penanaman karakter pada masa generasi Z. Langkah pembaharuan perlu dilakukan dalam menangani pendidikan kaum muda di masa generasi Z. Dengan sendirinya deras arus perubahan tidak akan mampu menandingi pendidikan karakter jati diri bangsa, mereka akan tetap menjadi diri sendiri yang beridentitas Indonesia yang mempunyai nilai luhur budi pekerti sebagai pedoman dalam berfalsafah negara dan segala apa yang dilakukan.

Lilik Suhartatik memiliki pemikiran tentang keberhasilan yang diraih oleh peserta didik dengan pendidikan kecakapan dalam bersikap dan bertindak yang mampu membentuk karakter pada diri kaum muda. Bisa disederhanakan bahwa karakter yang baik dimulai dengan kemampuan kecakapan dalam menghadapi situasi kehidupan dengan mental yang telah tertanam sejak dini dari hasil pendidikan orang tua dan pendidik. Menjadi penting pendidikan karakter yang telah dilakukan oleh pendidik mampu menorehkan tinta pedoman bagi kaum muda dalam bersikap sesuai jati diri bangsa.

Kepekaan terhadap nilai kearifan lokal yang melekat pada diri bangsa harus selalu dijaga melalui penanaman pendidikan karakter yang diharapkan bisa menjawab arus perubahan secara global dan dinamis. Pendidikan karakter bisa menjadi media dalam mewujudkan sikap dan tindakan yang baik dalam menyikapi situasi pandemi covid-19. Pendidik diharapkan mampu memberikan inovasi kreatif bersama menanggulangi dampak krisis akibat wabah pandemi.

Munculnya perubahan perilaku peserta didik yang lebih baik dari adanya penanaman pendidikan karakter akan mampu menjawab situasi pandemi covid-19, penerapan 5 
M+1D : mencuci tangan, menjaga jarak, memakai masker, mengurangi mobilitas, menghindari kerumunan, dan doa. Nilai budaya luhur bangsa mengajarkan arti kebersihan tangan, menggunakan tangan untuk kebaikan bersama, menjaga jarak dari perilaku yang menyimpang, memakai masker dalam menjaga tutur kata untuk tetap santun, beretika, dan beradab, mengurangi mobilitas dalam konteks nilai budi pekerti ialah menghindari pergerakan yang mengganggu ketertiban masyarakat, menghindari kerumunan ialah tidak bergerombol dalam hal sikap kurang baik yang dapat merugikan, diri sendiri, keluarga, sekolah, dan masyarakat secara universal, serta doa merupaka senjata paling ampuh bangsa ini dalam mewujudkan Indonesia Baldatun Thoyyibatun Warrobun Ghofur. 

Peningkatan SDM Unggul Berkompetensi selama Pandemi" pembahasannya banyak ditorehkan para pakar pendidikan berbagai pemikiran dengan narasi yang ringan dan mudah dipahami terkait dengan eksistensi penyelenggaraan berbagai bidang keilmuan. Bagaimana eksistensinya sangat perlu dibahas dari berbagai sudut pandang para pakar pendidikan ditengah pemikiran antara pesimis dan optimis bahwa belajar daring di tengah kondisi pandemi covid-19 akan menurunkan hasil belajar oleh karena sulitnya melakukan pengawasan sejauh mana siswa di rumah serius belajar secara daring tanpa pengawasan langsung dari guru dan orangtua.

Semoga tulisan ringan dengan berbagai topik yang menarik disampaikan para penulis, memberi manfaat bagi para pembaca, guru, siswa, orangtua. Upaya menghilangkan virus Covid-19 terus dilakukan Pemerintah RI tetapi penyiapan SDM unggul tidak boleh terhenti olehkarena ganasnya penyebaran Virus corona yang berimbas membuat banyak pihak berpikir pesimis dan optimis yang bercampur aduk dalam pikirannya termasuk para guru dan siswa.

\section{Akademia Pustaka}

Perum. BMW Madani Kavling 16, Tulungagung

https://akademiapustaka.com/

@ redaksi.akademia.pustaka@gmail.com

f) @redaksi.akademia.pustaka

[0]@akademiapustaka

081216178398

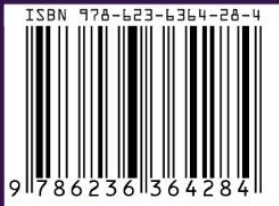

